\title{
'MID-LIFE GREENNESS': ENVIRONMENTAL CONSCIOUSNESS AMONG EUROPEAN CONSUMERS
}

\author{
by \\ Benjamin Beer \\ Thesis \\ ENVIRONMENTAL STUDIES 593 \\ [2013] \\ as partial fulfilment of requirements for the degree of \\ Master of Environmental Studies
}

A 90 point thesis submitted to Victoria University of Wellington,

School of Geography, Environment and Earth Sciences

Victoria University of Wellington

[15 February, 2013] 


\section{Abstract}

Identifying characteristics of green consumers has proven to be a complex undertaking for many researchers and no clear consensus yet exists. This is particularly true of the effect of age on awareness of environmental effects. My aim in this study is to model the relationship between age and environmental consciousness using a large sample of over twenty six thousand respondents in 28 countries to a specially designed survey requested by the European Commission.

I use the 2009 Flash Eurobarometer survey (no. 256) designed to address European attitudes towards sustainable consumption. I choose six questions from the survey in order to capture measures of environmental knowledge, attitudes and behaviour. Using multiple regression analysis, I test for the influence of age on environmental consciousness after controlling for gender, education level, occupation and urban vs. rural residence. The results reveal an interesting 'inverse U' shape of environmental consciousness by age for both men and women implying that environmental consciousness peaks at middle age. Extending the regression into multilevel modelling, allows me to test for variations in the inverse $\mathrm{U}$ shape across countries of Europe. The results indicate country level variations in both the level and shape of the curve from one country to another. Although similar in many countries, caution is required in making gross generalisations about age related sustainable consumption patterns in Europe as a whole.

Keywords: Green consumption, cross-country analysis, age segmentation, environmental consciousness in Europe. 
Chapter 1. Introduction 1

1.1. The history of green consumption 3

1.2. Consumption trends in Europe 6

1.3. Summary and research objectives $\quad 7$

Chapter 2. Literature Review 9

2.1. Age 13

2.2. Gender 18

2.3. Education Level 19

2.4. Social class (Income and Occupation) 19

2.5. Residence (Urban vs. Rural) 21

2.6. Cross-country analysis $\quad 22$

$\begin{array}{ll}\text { 2.7. Summary } & 26\end{array}$

$\begin{array}{ll}\text { Chapter 3. Methodology } & 27\end{array}$

3.1. Survey 28

3.2. Dependent variables $\quad 29$

3.3. Age and $\mathrm{Age}^{2} \quad 31$

3.5. Control Variables $\quad 32$

3.6. Modelling and summary $\quad 37$

$\begin{array}{ll}\text { Chapter 4. Analysis } & 38\end{array}$

4.1. Responses to environmental awareness and concern $\quad 38$

4.2. Responses to the four policy questions 41

4.3. Age distribution $\quad 42$

4.4. Age and its effect on environmental awareness 44

4.5. Age and its effect on environmental concern 51

4.6. Age and policy options $\quad 54$

4.7. The influence of the control variables 57

4.8. Summary 64

Chapter 5. Inter-country variations in middle age greenness $\quad 65$

5.1. Some descriptive results $\quad 67$

5.2. A multilevel model of environmental awareness $\quad 78$

5.3. A multilevel model of environmental concern $\quad 88$

$\begin{array}{ll}\text { Chapter 6. Conclusion. } & 93\end{array}$

6.1. Extensions 95

$\begin{array}{ll}\text { References } & 97\end{array}$

$\begin{array}{ll}\text { Appendices } & 106\end{array}$ 
Table 2.1: List of published studies that investigate relationships between environmental consciousness and selected demographic variables and their results (1972-2011)

Table 3.1: List of countries used in the 2009 Eurobarometer Survey and the EU27 weightings

Table 3.2: Descriptive statistics of the independent variables

Table 3.3: 2009 Eurobarometer survey responses by education

level

Table 3.4: Cross tabulation of the 2009 Eurobarometer survey responses by education level and age group

Table 3.5: List of education dummy variables used in my analysis

Table 3.6: List of occupation dummy variables used in my analysis

Table 4.1: Awareness of product impact on the environment

Table 4.2: Awareness of the environmental impact of products bought and used, by age group

Table 4.3: Concern for product impact on the environment 39

Table 4.4: Concern of the environmental impact of products 40 bought and used, by age group

Table 4.5: Importance of eco-labels on purchasing decisions 40

Table 4.6: Support for mandatory carbon-footprint labels 41

Table 4.7: Awareness of buying products with the EU flower ecolabel 42

Table 4.8: Support for a voluntary environmental code of 42 conduct for retailers

Table 4.9: 2009 Eurobarometer survey responses by age group 43

Table 4.10: Regression table showing the marginal effect each 45 education level has on environmental awareness

Table 4.11: Ordinal logit results for the awareness 46 of product impact on the environment by age group

Table 4.12. Regression results for the awareness of the environmental 49 impact of products people buy by age

Table 4.13: Regression results for the awareness of product impact on the environment by age group

Table 4.14: Concern for product impact on the environment 
Table 4.15: Regression results for the level of concern of environmental impact of products people buy by age

Table 4.16: Regression results for the awareness of product impact on the environment by age group

Table 4.17: Binary variables for the importance of eco-labels on purchasing decisions

Table 4.18: Regression results for the importance of eco-labels on purchasing decisions

Table 4.19: Results of multiple regression analyses covering awareness of environmental impact of products (with controls)

Table 4.20: Results of multiple regression analysis covering awareness of environmental impact of products (with controls)

Table 4.21: Results of multiple regression analyses covering concern of environmental impact of products (with controls)

Table 4.22: Results of multiple regression analysis covering concern over the importance of environmental impact of products (with controls)

Table 5.1: Percentage distribution of responses to level of awareness, by country 67

Table 5.2 Percentage distribution of responses to level of concern, by country

Table 5.3: Ordinary least squares model of awareness based on individual attributes alone

Table 5.4 Ordinary least squares model of awareness based on individual attributes plus country fixed effects

Table 5.5: Selected characteristics of countries in Europe, 2008-2009

Table 5.6: The influence of country characteristics on awareness, controlling for 76 attributes of respondents

Table 5.7: Testing for the presence of country effects in when awareness peaks in middle age. A multilevel model

Table 5.8: Testing for the presence of country effects in when awareness peaks in middle age along with the slopes

Table 5.9: Testing for the presence of country effects in when awareness peaks in middle age along with the slopes, allowing for correlation between the intercepts and slopes

Table 5.10: Estimates of age and country effects in the multilevel model of concern for the impact of products on the environment 
Figure 2.1: Graph showing the relationship between environmental concern in selected countries and GDP per capita (PPP), 2010

Figure 2.2: Graph showing the relationship between environmental concern in selected countries and CO2 emissions per unit of GDP, 2010

Figure 3.1: Scatter graph showing the age when full-time education finished and age of the respondent

Figure 4.1: The distribution of ages across the sample of European respondent, ages 15+

Figure 4.2: Age distribution for EU27, 1990 and 2010 (\% of total population), by gender

Figure 4.3: The influence of age on the predicted probability of responses to Question 1 (awareness of product impact on the environment)

Figure 4.4. The predicted level of awareness of the environmental impact of products people buy by age

Figure 4.5: The predicted level of awareness and concern for the environmental 52 impact of products people buy by age

Figure 4.6: The predicted probability of importance of ecolabels in purchasing decisions

Figure 4.7: The predicted probability of support for various environmental policy initiatives

Figure 4.8: Predicted level of awareness of environmental impact of products with and without controls

Figure 4.9: Predicted level of awareness of environmental impact of products across age with and without controlling for education and occupations

Figure 4.10: Predicted level of concern over the importance of environmental impact of products across age with and without controlling for education and occupations

Figure 5.1:Differences in environmental awareness scores by country

Figure 5.2: Differences in environmental impact scores by country

Figure 5.3: The distribution of ages by country (ages $15+$ )

Figure 5.4: Variation in random intercepts predicted for countries based on the quadratic model of age effects on awareness of environmental impacts of purchased products 
Figure 5.5: Variation in random slopes predicted for countries based on the quadratic model of age effects on awareness of environmental impacts of purchased products. Europe, 2009

Figure 5.6: Predicted levels of awareness by age in Germany and Portugal compared to the European average, 2009

Figure 5.7: The best linear predictions of deviations of countries from the European average with respect to the effect of age on awareness of purchased product impacts. Europe 2009

Figure 5.8: Predicted levels of awareness by age in Finland and Lithuania compared to the European average, 2009

Figure 5.9: The best linear predictions of deviations of countries from the European average with respect to the effect of age on concern over the environmental impact of purchased product impact 


\section{Chapter 1. Introduction}

During the 1992 Earth summit, it was acknowledged that "the major cause of the continued deterioration of the global environment is the unsustainable pattern of consumption and production, particularly in the industrialised countries" (UNCED, 1992, cited by Robins, 1999). It is estimated that at current consumption levels in Western society alone, we will require the equivalent of three earth planets to continue to support this lifestyle (Carlisle \& Hanlon, 2007). Succinctly described, “...'reckless consumption' of planetary resources has led to, among other things, accelerated rates of climate change, air and water pollution, deforestation, soil degradation and species loss" (Soron, 2010: p.172).

From 1960 until the late 1990s, global consumption quadrupled in size (Robins, 1999) and there is little evidence that this rate of increase is slowing down. The expansion of consumption throughout the world has been driven in part by increasing consumer wealth and population size (Mont and Plepys, 2007), both of which are predicted to continue rising well into the twenty-first century (Veenhoven, 2004). A vast amount of research now highlights the need to transform an unsustainable consumer industry into a more sustainable one (eg., Robins, 1999; Connolly and Prothero, 2003; Sanne, 2005; Schor, 2005; Mont and Plepys, 2007; Pepper et al, 2009; Hume, 2009; Peattie and Peattie, 2009; Young et al; 2009; Wells et al. 2011).

Despite the scientific evidence, reducing consumption levels is seldom a priority agenda for governments or most businesses in the developed world. In fact any such limitation is usually seen as an infringement on consumer sovereignty (Sanne, 2002), and this may explain the unusual degree of silence which pervades political discourses over environmental ramifications of unsustainable consumption (Soron 2010). At best, governments make only modest policy changes, adopting strategies of 'sustainability by stealth' (Robins, 1999: p. 12) and while governments may acknowledge the environmental repercussions of over-consumption, there is a reluctance to address the deeper question of whether the level of consumption reached today is actually healthy for people and the environment (Jackson, 2005). A paradigm shift away from materialistic lifestyles and a reduction in consumption expectations is regarded by many as an important step towards sustainable consumption (e.g., Ahuvia 
and Wong, 1995; Robins, 1999; Burroughs and Rindfleisch, 2002; Hume, 2009).

Within the last forty years, various businesses combined innovation in production with targeted market audiences and have developed a wide range of 'environmentally friendly products ${ }^{1}$ (Peattie \& Peattie, 2009). Concern over the environmental impact of consumption has created a niche consumer market commonly referred to as 'green consumers'.2 Studies exploring green consumption have been numerous (e.g., Balderjahn, 1988; Shrum et al. 1995; Roberts 1996a; 1996b; Straughan and Roberts, 1999; Laroche et al. 2001; Diamantopoulos et al. 2003; Gilg et al. 2005; Jain and Kaur, 2008) and "Research in this tradition has...sought to identify and analyse green consumption values, attitudes and behaviours as well as explore ways to segment and target green consumers" (Schaefer and Crane 2005: p.79).

A leading driver of research on green consumption is the desire to understand the motivations of consumers that express an awareness of and deliberately choose environmentally friendly products over standard ones. For example, Peattie and Crane, (2005: p.365-366) suggest that,

"Although some green brands were significantly more sustainable than conventional offerings, the degree to which they made substantive progress towards sustainability is very doubtful. In one way, they may have acted as a "pressure valve" allowing concerned consumers to moderately change their consumption behaviour in a way that made them feel as though they were "doing their bit"...green marketing has acted as a bridge...between people's environmental concern and their desire to maintain the western consumer lifestyle."

Knowledge of those segments in society that deliberately choose to make green purchases is helpful to key stakeholders such as sustainability advocates, marketing companies and green product manufacturers. Hence there is a continuing search for the characteristics of those who support green consumption, or in other words, fit the 'green consumer profile'. The ability to actually profile the green consumer continues

\footnotetext{
${ }^{1}$ Environmentally friendly products are defined as “...ecologically safe products that can facilitate the long term goal of protecting and preserving our natural habitat." (Datta, 2011: p. 126)

2 The term 'green' is interchangeable with 'pro-environmental' and is broadly defined as indicating "concern with the physical environment (air, water, land)" (Shrum et al. 1995: p.72). A green consumer implies that they choose to make purchases that have minimal adverse impact on the natural environment.
} 
to be a complex undertaking (Diamantapoulos et al. 2003), much to the frustration of those wishing to target favourable market segments.

There are several reasons why identifying green consumers has been difficult. Firstly as McDonald et al. (2009) found green consumption behaviour is not consistent over different product lines. Secondly there has been significant change in the way people perceive environmental issues since research began in the 1970s (Roberts 1996b; Kilbourne and Beckmann, 1998; Diamantopoulos et al. 2003). Thirdly, many previous studies have failed to acknowledge the gap between environmental attitudes and environmental behaviour (Diamantopoulos et al. 2003). Fourthly, many researchers have found demographic variables to be an unreliable measure of the green consumer, having produced many conflicting results in the past (e.g. Balderjahn, 1988; Shrum et al. 1995; Roberts 1996b; Straughan \& Roberts, 1999; Laroche et al. 2009).

In the research I report below I have attempted to avoid some of the problems listed above - notably by firstly allowing the consumer to identify the product and in so doing use the consumers attributes to help control for product differentiation. Secondly I focus on attitudes as they have been recorded in 2009. Thirdly, I concentrate on one demographic variable (age) in closer detail to that of most previous studies in order to assess why there might have been conflicting results for the influence of age on environmental consciousness in the past.

The aim of my research is twofold. To identify the demography of the green

consumer - focussing predominantly on the influence age has on environmental consciousness, and to show the degree to which the green consumer profile varies across countries in the European Union.

\subsection{The history of green consumption}

Long before there was awareness of the threats to environmental sustainability posed by global warming and ozone layer depletion, prominent authors such as Locke, Mill and Smith in $17^{\text {th }}$ and $18^{\text {th }}$ century England warned of resource scarcity and the 
limitations to endless growth (Kilbourne and Beckmann, 1998). However it took several centuries before Western society began to take these concerns seriously. Beginning in the 1960s, an 'environmental movement' took shape in many countries throughout the world which embraced ecology, and promoted healthier, greener ways of living with focus on reducing pollution and energy conservation (Straughan and Roberts, 1999). Rachel Carson's 1962 book Silent Spring acted as a catalyst for ecological awareness and added impetus to the pro-environment fervour associated with the counter-culture movement of the time (Kilbourne and Beckmann, 1998).

Since the 1960s the concept of green consumption has gone through several iterations (Lee, 2008; Straughan and Roberts, 1999). In the 1970s, the marketing world began to take an interest in promoting green products. In order to tap an the increasing number of environmentally conscious consumers (Zimmer et al. 1994), the first attempts at profiling green consumers began (e.g., Anderson and Cunningham, 1972; Tognacci et al. 1972; Kinnear et al. 1974; Webster, 1975). In the mid 1970s, pressure by environmental campaigners in many developed countries led to numerous legislative changes such as the prohibition of certain toxic chemicals in product manufacture lines (Finisterra do Paço and Raposo, 2008). This resulted in decreased environmental concern by many consumers.

However, a succession of environmental catastrophes in the 1980s such as Chernobyl, Three Mile Island, Exxon Valdez oil spill and the discovery of the ozone layer hole brought environmental issues firmly back into the spotlight (Kilbourne and Beckmann, 1998). Since their occurrence, awareness of environmental issues have become more the social norm, especially in Western countries (Diamantopoulos et al. 2003), and many organisations in the last two decades have actively sought to create more environmentally friendly workplace standards with the renewed level of concern over environmental sustainability (Hume, 2009). Since the 1990s, marketing companies have attempted to exploit the expanding green product market. Over 700 products advertised as being green were introduced from the mid 1980s to mid 1990s in the US alone (Zimmer et al. 1994).

The 1990s is sometimes referred to retrospectively as the 'decade of the environment' 
(Pujari and Wright, 1996, cited by Fotopoulos and Krystallis, 2002). Market research polls revealed consumers were willing to pay more on environmentally friendly products than the previous decade (Datta, 2011) and as a result, green products entered the market in unprecedented numbers. However, the size of the market was over-estimated and turnover of green products fell short of expectations (Wong et al. 1996; Peattie and Crane, 2005; Lee, 2008). Research in the UK has suggested that in the 1990s, the proportion of green consumers increased only slightly where as the proportion of consumers who did not change their spending habits increased more significantly (Wong et al. 1996).

Studies have identified a gap between environmental concern and pro-environmental behaviour (e.g., Wong et al. 1996; Laroche et al. 2001; Peattie and Crane, 2005; Lee, 2008; Franzen and Meyer, 2009; Freymeyer and Johnson, 2010). There are several reasons. Firstly, green products generally cost more than standard products - they generally involve more labour, production ingredients are more expensive, production is on smaller scales (Brécard et al. 2009), and this has led to some consumer resistance (Laroche et al. 2001). Secondly, willingness to pay and actually paying are two different things for surveys have suggested American citizens were willing to pay up to $40 \%$ more for environmentally friendly products (Laroche et al. 2001). Franzen and Meyer (2009) use the ISSP 2000 study to show that $45 \%$ of those surveyed in the USA expressed willingness to pay higher prices to help preserve the environment and around $33 \%$ were even willing to pay higher taxes or tolerate reduced standard of living for the same goal. They conclude as a result that environmental concern will only translate into green behaviour if the marginal financial cost is low (for example, recycling). Thirdly, many consumers were sceptical of the claim that green products were in fact as environmentally safe as claimed and were often distrustful of the companies selling them (Peattie and Crane, 2005; Wong et al. 1996), suggesting that consumers have since overcome scepticism towards promotions of eco-friendly products. This may have come from consumers being more assured of green product authenticity due to increased environmental legislation and government regulation (Finisterra do Paço and Raposo, 2010) in developed regions such as North America and Europe.

In the last ten years the green product industry has experienced renewed productivity. 
For example, recently conducted surveys show 50\% of Americans claim to actively search for green products on shelves and $61.5 \%$ of Australians are willing to pay more for environmentally safe items (Mostafa, 2009). At the turn of the millennium, green products secured a 20-30\% market share in the UK (Fotopoulos and Krystallis, 2002) and in 2006 it was estimated the green product industry reached over \$200 billion USD (Gupta and Ogden, 2009). It is to the European experience that I now turn.

\subsection{Consumption trends in Europe}

Creating a more sustainable consumer industry is an important goal with the European Union (Eurostat 2010; 2011a). The EU sustainable development strategy has an overall aim which is "To promote sustainable consumption and production patterns" and to "...seek to increase its global market share in the field of environmental technologies and eco-innovations" (Eurostat, 2011a: p. 84). As stated in their Sustainable Development in the European Union 2011 monitoring report, "Sustainable development is a fundamental and overarching objective of the European Union (EU), aiming to continuously improve the quality of life and wellbeing for present and future generations, by linking economic development, protection of the environment and social justice" (ibid p. 12).

There have been several initiatives introduced to the EU in recent years to assist the goal of promoting sustainable consumption. One such example is the establishment of the EU ecolabel in 1992, which at present,

"covers around 25 types of products and services, with further groups being continuously added. These include cleaning products, household appliances, electronic equipment, paper products, textiles, home and garden products, lubricants, and services such as tourist accommodation. The EU ecolabel is recognised throughout the 27 EU Member States as well as in Norway, Liechtenstein and Iceland" (Eurostat, 2010: p. 67-68).

The EU seeks to support businesses marketing eco-products with the eco-label and in 2008, the "eco-industry in the EU-27 countries had a turnover of 319 billion EUR [which], accounted for $2.5 \%$ of EU GDP, and employed 3.4 million people" (EEA online, 2011). 
The EU also supports a 'Green Public Procurement' initiative which means “...public authorities and services take account of environmental factors when procuring products, services or works" (Eurostat, 2010: p. 48). Nearly all EU-27 members have adopted or are in the process of adopting this initiative. Austria, Germany, Denmark, Finland, the Netherlands, Sweden and the United Kingdom are the leading countries in implementing Green Public Procurement (Eurostat, 2010). In 2006/2007 these seven countries produced a 55\% share in the total number of contracts (ibid).

Domestic material consumption $^{3}$ per capita in the EU increased between 2000 and 2007 in the EU region (Eurostat, 2011a). Not surprisingly, there are some differences between countries in both consumption and production trends. For example, Ireland and Finland had a significantly higher domestic material consumption per capita than the EU-27 average (Eurostat, 2011a). Germany, France, Italy and the UK, representing the most populous countries in the EU, had lower domestic material consumption levels than the EU-27 average (ibid). In the period 2000-2007, several countries experienced increased domestic material consumption including in particular Estonia, Latvia, Lithuania, Malta, Bulgaria and Romania (ibid). The latter three countries experienced an increase in domestic material consumption that exceeded the increase in their GDP growth. The result was decreased resource productivity (ibid). These are some examples of the varying trends between European countries in relation to consumption which leads me on to my research objectives relevant to the examination of the 2009 Eurobarometer survey.

\subsection{Summary and research objectives}

Growing awareness of the environmental impacts of global consumption has created a market for environmentally friendly products, and a large amount of research has tried to determine the characteristics of those who buy green products. However, there has been, and still is a general lack of consensus regarding the demography of the green consumer.

\footnotetext{
${ }^{3}$ Defined by Eurostat (2011: p. 92) as a measure of "the total amount of materials directly used by an economy. It is defined as the annual quantity of raw materials extracted from the domestic territory of an economy plus all physical imports minus all physical exports."
} 
There are several reasons why I am conducting this research. Firstly, the correlation between age and environmental consciousness is probably one of the least agreed upon relationships (as will be shown in the literature review). There is sufficient evidence for me to believe that the relationship between age and environmental consciousness is still not very well understood. Therefore I want to pay particular attention to this in my analysis. My first objective is to pay particular attention to the influence of age on pro-environmental consciousness.

Secondly, the relationship between age and environmental consciousness might be the result of events and circumstances common to particular life stages. My second objective is to focus on whether the relationship between age and environmental consciousness prevails even when controlling for other variables such as education level and occupation.

Thirdly, I want to better understand how the relationship between age and environmental consciousness varies by country. Therefore, it was a promising opportunity to use the 2009 Eurobarometer survey, covering 28 European countries to assess my third objective: to ascertain the stability of the relationship between age and environmental consciousness across different countries within Europe.

I now will explore a range of relevant previous studies to assess how both age and various control variables influence environmental concern. 


\section{Chapter 2. Literature Review}

The illusive search for the profile of the green consumer continues. USA based researchers, Berkowitz and Lutterman (1968), Anderson and Cunningham (1972), Tognacci et al. (1972), Kinnear et al. (1974), as well as Webster (1975) were some of the first to conduct analysis in this field. Berkowitz and Lutterman (1968) concluded that a green consumer is likely to be a young female, highly educated, and of a higher socio economic status. Tognacci et al. (1972) also agreed that they would be young, highly educated and with good incomes and occupations. Both Anderson and Cunningham (1972) and Webster (1975) drew similar conclusions.

Beginning in the early 1970s and continuing until the late 1990s, the majority of studies examining the relationship between various demographic variables and green consumer consciousness were conducted in the USA (Jain and Kaur, 2008). From the turn of the millennium onwards, similar studies began to be conducted in Europe (e.g., Diamantopoulos et al. 2003; Gilg et al. 2005; Haanpaa, 2007; Abeliotis et al. 2010; Finisterra do Paço and Raposo, 2010; Roos and Nryud 2008, Gatersleben et al. 2002; Pepper et al. 2009; Banyte et al. 2010), Asia (e.g., Chan, 2000; Haron et al. 2005; Shen and Saijo, 2008; Jain and Kaur, 2008; Lee; 2008; 2009; Sinnappan and Rahman, 2011; Datta, 2011), the Middle East (Alibeli and Johnson, 2009; Bodur and Sarigollu 2005; Aydin and Çepni, 2010; Mostafa, 2009; Tantawi et al. 2009), South America (Pinto et al. 2011; Milfont and Duckitt, 2009) and Australasia (Scott and Casey, 2006; Kilbourne and Polonsky, 2005; Milfont and Duckitt, 2009). What was once the realm of North American research is now a global research agenda.

Table 2.1 lists my reviewed studies which examine the influence of a range of independent variables on environmental consciousness ${ }^{4}$ by date published. The variables tabulated include age, gender (sex), education level (educ.), occupation (occ.), income (inc.) and urban or rural residence (res.). Although the variable 'income' was not tested in my study, it is still listed in Table 2.1 because it is one of the most commonly used variables in green consumer profile research. These

\footnotetext{
${ }^{4}$ Environmental consciousness (also known as environmental concern) is a term I frequently use in my thesis that describes a state of mind which influences a persons' knowledge, attitudes or behaviour so that the protection of the environment is considered important.
} 
references were assembled after an extensive search for studies using demographic variables in particular to establish characteristics of the green consumer. Whilst the majority of these articles tested for some or most of the tabulated variables, others exclusively focused on levels of environmental concern between rural and urban residents (e.g., Tremblay and Dunlap, 1977; Lowe and Pinhey.1982 and Berenguer et al. 2005).

Some authors (such as Diamantopoulos et al, 2003) make distinctions based on three categories of environmental consciousness: 1) knowledge 2) attitude and 3) behaviour. However, not all authors separate their results by these criteria and this has been reflected in the table with one single result for each variable. In this regard, where there were differing results between knowledge, attitude and behaviour, the result which was statistically most significant was applied. Fifty-one studies have been reviewed and include the most prominent in this field of research.

The entries in Table 2.1 denote either a positive (' 1 ') or negative ('0') statistically significant correlation between dependent (pro-environmental) and independent variables. A positive result means that the result was the 'higher' of the two outcomes (includes: age, education level, occupation and income). Regarding gender and residence the predicted result was female (1) and for residence the predicted result was urban (1). A $1 / 0$ entry means the result was statistically significant but the result was neither positive (1) or negative (0) per se, but perhaps somewhere in-between. ${ }^{5} \mathrm{~A}$ NS entry means the result was not statistically significant and a blank space signifies that that particular demographic variable was not tested in the study.

\footnotetext{
${ }^{5}$ For example, it was found that in the results of Finisterra do Paço and Raposo, (2010), Abeliotis et al. (2010) and Bantye et al. (2010) the middle age group had the highest levels of environmental consciousness, so the result was neither 1 nor 0 exactly, so instead, the result was denoted 1/0.
} 
Table 2.1: List of published studies that investigate relationships between environmental consciousness and selected demographic variables and their results (1972-2011).

\begin{tabular}{|c|c|c|c|c|c|c|c|c|c|}
\hline \multirow[t]{3}{*}{ Author } & \multicolumn{3}{|c|}{ Survey } & \multicolumn{6}{|c|}{ Independent Variable } \\
\hline & \multirow[t]{2}{*}{ Year } & \multirow[t]{2}{*}{ Size } & \multirow[t]{2}{*}{ Place } & Age & Sex & Educ. & Occ. & Inc. & Res. \\
\hline & & & & $\begin{array}{l}\text { Older }= \\
1\end{array}$ & $\mathrm{~F}=1$ & $\begin{array}{l}\text { Higher } \\
=1\end{array}$ & $\begin{array}{l}\text { Higher } \\
=1\end{array}$ & $\begin{array}{l}\text { Higher } \\
=1\end{array}$ & $\begin{array}{l}\text { Urban= } \\
1\end{array}$ \\
\hline $\begin{array}{l}\text { Anderson and } \\
\text { Cunningham } \\
1972\end{array}$ & 1971 & 1200 & USA & 0 & & NS & 1 & NS & \\
\hline $\begin{array}{l}\text { Tognacci et al } \\
1972\end{array}$ & $\mathrm{~N} / \mathrm{A}$ & 141 & USA & 0 & & 1 & 1 & 1 & \\
\hline $\begin{array}{l}\text { Kinnear et al } \\
1974\end{array}$ & 1971 & 1200 & USA & NS & NS & NS & NS & 1 & \\
\hline Webster 1975 & N/A & 231 & USA & & 1 & & NS & 1 & \\
\hline $\begin{array}{l}\text { Tremblay and } \\
\text { Dunlap } 1977\end{array}$ & 1970 & 866 & USA & & & & & & 1 \\
\hline $\begin{array}{l}\text { Murphy et al } \\
1978\end{array}$ & 1975 & 179 & USA & 0 & 1 & 1 & 1 & & \\
\hline $\begin{array}{l}\text { Van Liere and } \\
\text { Dunlap } 1980\end{array}$ & 1976 & 806 & USA & 0 & NS & 1 & NS & NS & 1 \\
\hline $\begin{array}{l}\text { Lowe and } \\
\text { Pinhey } 1982\end{array}$ & $\mathrm{~N} / \mathrm{A}$ & $\mathrm{N} / \mathrm{A}$ & USA & & & & & & 1 \\
\hline $\begin{array}{l}\text { Balderjahn } \\
1988\end{array}$ & 1980 & 1945 & Germany & 1 & 0 & 1 & 1 & 1 & 0 \\
\hline $\begin{array}{l}\text { Samdhal and } \\
\text { Robertson } \\
1989\end{array}$ & 1978 & 2131 & USA & 1 & NS & 0 & NS & 0 & 1 \\
\hline $\begin{array}{l}\text { Arcury and } \\
\text { Christianson } \\
1990\end{array}$ & $\begin{array}{l}1984 \\
1988\end{array}$ & $\begin{array}{l}441 / \\
653\end{array}$ & USA & 0 & 0 & 1 & & 1 & 1 \\
\hline $\begin{array}{l}\text { Schahn and } \\
\text { Holzer } 1990\end{array}$ & 1987 & 167 & Germany & 1 & 1 & NS & & & \\
\hline $\begin{array}{l}\text { Roper } \\
\text { Organization } \\
1992\end{array}$ & 1992 & N/A & $\begin{array}{l}\text { North } \\
\text { America }\end{array}$ & NS & 1 & 1 & 1 & 1 & 1 \\
\hline $\begin{array}{l}\text { Jones and } \\
\text { Dunlap } 1992^{6}\end{array}$ & $\begin{array}{l}1973- \\
1990 \\
\end{array}$ & N/A & USA & 0 & & 1 & 1 & & 1 \\
\hline $\begin{array}{l}\text { Zimmer et al } \\
1994\end{array}$ & N/A & 118 & USA & 0 & & 1 & & 1 & 1 \\
\hline $\begin{array}{l}\text { Scott and } \\
\text { Willits } 1994\end{array}$ & 1990 & 3632 & USA & 1 & NS & 1 & & 1 & \\
\hline $\begin{array}{l}\text { Shrum et al, } \\
1995\end{array}$ & 1990 & 3690 & USA & NS & NS & NS & & & \\
\hline $\begin{array}{l}\text { Nevitte and } \\
\text { Kanji } 1995\end{array}$ & 1990 & 1730 & Canada & NS & 1 & & & & $1 / 0$ \\
\hline $\begin{array}{l}\text { Meffert and } \\
\text { Bruhn } 1996^{7}\end{array}$ & 1994 & 1544 & Germany & NS & 0 & NS & NS & NS & \\
\hline $\begin{array}{l}\text { Roberts } \\
1996 b\end{array}$ & 1991 & 1503 & USA & 1 & 1 & 1 & NS & 0 & NS \\
\hline $\begin{array}{l}\text { Mainieri et al } \\
1997\end{array}$ & 1993 & 201 & USA & NS & 1 & NS & & NS & \\
\hline Berger 1997 & 1991 & 43,000 & Canada & & & 1 & NS & 1 & 1 \\
\hline
\end{tabular}

\footnotetext{
${ }^{6}$ Data examined over an 18 year period, (all others are for one year time frame only).

${ }^{7}$ Findings sourced from Diamantopoulos et al, (2003)
} 


\begin{tabular}{|c|c|c|c|c|c|c|c|c|c|}
\hline \multirow[t]{3}{*}{ Author } & \multicolumn{3}{|c|}{ Survey } & \multicolumn{6}{|c|}{ Independent Variable } \\
\hline & Year & Size & Place & Age & Sex & Educ. & Occ. & Inc. & Res. \\
\hline & & & & $\begin{array}{l}\text { Older }= \\
1\end{array}$ & $\mathrm{~F}=1$ & $\begin{array}{l}\text { Higher } \\
=1\end{array}$ & $\begin{array}{l}\text { Higher } \\
=1\end{array}$ & $\begin{array}{l}\text { Higher } \\
=1\end{array}$ & $\begin{array}{l}\text { Urban }= \\
1\end{array}$ \\
\hline Furman 1998 & 1995 & 430 & Turkey & NS & & NS & & & \\
\hline $\begin{array}{l}\text { Straughan and } \\
\text { Roberts, } 1999\end{array}$ & $\mathrm{~N} / \mathrm{A}$ & 235 & USA & NS & NS & & NS & NS & \\
\hline Chan 2000 & N/A & N/A & $\begin{array}{l}\text { Hong } \\
\text { Kong }\end{array}$ & NS & NS & 1 & $1 / 0$ & 1 & NS \\
\hline Schultz 2001 & N/A & 1010 & USA & 0 & 1 & NS & & NS & \\
\hline $\begin{array}{l}\text { Laroche et al } \\
2001\end{array}$ & $\mathrm{~N} / \mathrm{A}$ & N/A & $\begin{array}{l}\text { North } \\
\text { America }\end{array}$ & NS & 1 & NS & NS & NS & \\
\hline $\begin{array}{l}\text { Gatersleben et } \\
\text { al } 2002\end{array}$ & 1995 & 2167 & $\begin{array}{l}\text { Netherland } \\
\mathrm{s}\end{array}$ & 1 & & 1 & & 0 & \\
\hline $\begin{array}{l}\text { Zarnikau } \\
2003\end{array}$ & $\mathrm{~N} / \mathrm{A}$ & 100 & USA & 0 & & 1 & & 1 & \\
\hline $\begin{array}{l}\text { Diamantopo- } \\
\text { ulos et al } \\
2003\end{array}$ & N/A & 1697 & UK & 0 & NS & 1 & & & \\
\hline $\begin{array}{l}\text { Berenguer et } \\
\text { al } 2005\end{array}$ & N/A & 185 & Spain & & & & & & 0 \\
\hline $\begin{array}{l}\text { Gilg et al } \\
2005\end{array}$ & 2002 & 1600 & UK & 1 & NS & 1 & & 1 & \\
\hline $\begin{array}{l}\text { Bodur and } \\
\text { Sarigollu } \\
2005\end{array}$ & $\mathrm{~N} / \mathrm{A}$ & N/A & Turkey & NS & NS & 1 & & 1 & \\
\hline $\begin{array}{l}\text { Casey and } \\
\text { Scott } 2006\end{array}$ & N/A & 292 & Australia & NS & 1 & 1 & & & \\
\hline Haanpaa 2007 & 2003 & 1370 & Finland & 1 & NS & 1 & & NS & \\
\hline $\begin{array}{l}\text { Saphores et } \\
\text { al. } 2007\end{array}$ & 2004 & $\mathrm{~N} / \mathrm{A}$ & USA & 0 & & 1 & & 1 & \\
\hline $\begin{array}{l}\text { Xiao and } \\
\text { Dunlap } 2007\end{array}$ & 1992 & $\begin{array}{l}1032 / 1 \\
011\end{array}$ & $\begin{array}{l}\text { North } \\
\text { America }\end{array}$ & 0 & 1 & 1 & NS & NS & NS \\
\hline $\begin{array}{l}\text { Shen and } \\
\text { Saijo } 2008\end{array}$ & 2006 & 1200 & China & 1 & 0 & 1 & NS & 1 & 1 \\
\hline $\begin{array}{l}\text { Jain and Kaur } \\
2008\end{array}$ & 2001 & 206 & India & NS & 1 & 1 & $1 / 0$ & 1 & \\
\hline $\begin{array}{l}\text { Roos and } \\
\text { Nryud } 2008\end{array}$ & N/A & N/A & $\begin{array}{l}\text { Sweden/ } \\
\text { Norway }\end{array}$ & NS & 1 & NS & & NS & \\
\hline $\begin{array}{l}\text { Alibeli and } \\
\text { Johnson } 2009\end{array}$ & N/A & 1282 & $\begin{array}{l}\text { Middle } \\
\text { East }\end{array}$ & & 1 & & 1 & 1 & \\
\hline $\begin{array}{l}\text { Thomson et al } \\
2009[\mathrm{~A}]^{8}\end{array}$ & $\mathrm{~N} / \mathrm{A}$ & 303 & USA & 0 & 1 & NS & & NS & \\
\hline $\begin{array}{l}\text { Thomson et al } \\
2009[\mathrm{~B}]^{9}\end{array}$ & N/A & 478 & USA & NS & 1 & 1 & & NS & \\
\hline $\begin{array}{l}\text { Pepper et al } \\
2009\end{array}$ & 2006 & 260 & UK & NS & NS & NS & NS & NS & \\
\hline $\begin{array}{l}\text { Franzen and } \\
\text { Meyer } 2009\end{array}$ & $\begin{array}{l}1993 / \\
2000\end{array}$ & N/A & Global & 1 & 1 & 1 & NS & 1 & \\
\hline $\begin{array}{l}\text { Abeliotis et al } \\
2010\end{array}$ & 2008 & 300 & Greece & $0 / 1$ & 1 & NS & & 0 & \\
\hline
\end{tabular}

${ }^{8}$ Study A - Consumers of Building Materials
${ }^{9}$ Study B - Furniture Consumers 


\begin{tabular}{|c|c|c|c|c|c|c|c|c|c|}
\hline \multirow[t]{3}{*}{ Author } & \multicolumn{3}{|c|}{ Survey } & \multicolumn{6}{|c|}{ Independent Variable } \\
\hline & Year & Size & Place & Age & Sex & Educ. & Occ. & Inc. & Res. \\
\hline & & & & $\begin{array}{l}\text { Older }= \\
1\end{array}$ & $\mathrm{~F}=1$ & $\begin{array}{l}\text { Higher } \\
=1\end{array}$ & $\begin{array}{l}\text { Higher } \\
=1\end{array}$ & $\begin{array}{l}\text { Higher } \\
=1\end{array}$ & $\begin{array}{l}\text { Urban= } \\
1\end{array}$ \\
\hline $\begin{array}{l}\text { Finisterra do } \\
\text { Paço and } \\
\text { Raposo, } 2010\end{array}$ & N/A & 887 & Portugal & $0 / 1$ & NS & 1 & 1 & 1 & \\
\hline $\begin{array}{l}\text { Milfont and } \\
\text { Duckitt } 2010\end{array}$ & N/A & $\begin{array}{l}314 / \\
229 / \\
468\end{array}$ & Global & 1 & 1 & & & & \\
\hline $\begin{array}{l}\text { Banyte et al. } \\
2010\end{array}$ & N/A & 105 & Lithuania & $0 / 1$ & 1 & 1 & & 0 & \\
\hline $\begin{array}{l}\text { Sinnappan } \\
\text { and Rahman } \\
2011\end{array}$ & N/A & 204 & Malaysia & 0 & NS & NS & NS & NS & \\
\hline $\begin{array}{l}\text { Pinto et al } \\
2011\end{array}$ & N/A & 400 & Brazil & 1 & NS & 0 & & & \\
\hline
\end{tabular}

The list of research spanning forty years provides interesting viewing. Some studies did not have success in finding statistically significant results across all or most of the independent variables (for example, Kinnear et al. 1974; Shrum et al. 1995; Straughan and Roberts, 1999; Pepper et al. 2009). However, there were also a large number of studies which provided statistically significant results that can provide some insight into the characteristics of the green consumer. These will now be listed.

\subsection{Age}

Some studies listed in Table 2.1 found green consumers to be older (e.g., Balderjahn, 1988; Samdhal and Robertson, 1989; Scott and Willits, 1994; Roberts 1996b; Gilg at al. 2005), other studies found them to be younger (e.g., Anderson and Cunningham, 1972; Tognacci et al. 1972; Van Liere and Dunlap 1980; Zimmer et al 1994; Diamantopoulos et al. 2003). My literature review suggests that the relationship between age and pro-environmental consciousness was fairly evenly split between favouring older and younger persons. Of the fifty-one reviewed studies, eleven found that older persons were more environmentally concerned, while fifteen determined younger persons were, only three found the middle age group were the greenest while sixteen studies gave results that were not significant statistically and the remaining six studies did not test for age.

The theory that younger persons were more environmentally concerned was 
prominent in the earliest years of research (Berkowitz and Lutterman, 1968; Anderson and Cunningham, 1972; Van Liere and Dunlap, 1980). Laroche et al, (2001) proposes that there has been a reversal since the early 1990s with older persons now more likely to show environmental concern. However, my literature review reveals that post 1990 , nine studies show positive correlations between age and pro-environmental consciousness, ten give negative results and fifteen studies found no statistical significance. Furthermore, more recent studies by Marquart-Pyatt (2007), Xiao and Dunlap (2007), Xiao and McCright (2007), Freymeyer and Johnson (2010) and Franzen and Meyer (2009) oppose this, maintaining that today younger persons fit the profile of the green consumer better. On the basis of my review of the literature there is insufficient evidence that any of the above conclusions regarding the relationship between age and green consumer consciousness stand out as being strongly supported.

In their literature review, Diamantopoulos et al. (2003) discovered that only two out of thirty-three studies gave significant results in the relationship between age and environmental knowledge (both were negative meaning environmental knowledge decreases with age). However, because of the large proportion of studies that did not find significant results, Diamantopoulos et al. (2003) put forward a null hypothesis that there is no relationship between environmental knowledge and age. After their own data was analysed, a weak negative relationship was revealed, suggesting that younger persons are slightly more likely to have greater environmental knowledge than older persons.

Van Liere and Dunlap, (1980) have argued that younger people are more likely to embrace the social change necessary for environmental protection where as older persons are more established in their habits and less malleable. However, as Diamantopoulos et al. (2003: p.471) argued,

"[researchers have] often found that age is negatively related to (intended) behavior, while those employing indicators of current behavior have found that older people display higher levels of green behavior...It is possible that such inconsistencies are due to a lack of resources among younger members of the population. Although younger people are likely to state that they will commit more resources to protecting the environment in the future...many do not currently have the financial security necessary to support environmental causes." 
These contrasting findings lead Diamantopoulos et al. (2003) to argue that any relationship between environmental behaviour and age per se would not be statistically significant (as their own results showed).

Jain and Kaur (2008) comment that whilst a few studies find a non-significant relationship between pro-environmental consciousness and age (for example, Kinnear et al. 1974; Meffert and Bruhn, 1996; Roper Organization, 1992; Shrum et al. 1995) the majority of studies actually do favour younger persons. Like Diamantopoulos et al. (2003), Jain and Kaur (2008) were interested in three distinct outcomes; environmental knowledge, attitude and behaviour. Their prediction was that all three would be negatively related to age and therefore in favour of younger persons while their results showed environmental attitudes and environmental behaviour were both negatively correlated with age, in some instances the strength of the statistical relationship was weak. The relationship between environmental knowledge and age was not statistically significant in their analysis.

It is important to note here that neither Diamantopoulos et al. (2003) or Jain and Kaur (2008) tested the potential non-linearity of the relationship between age and environmental concern specifically. Additionally, there are three possible reasons for the above discrepancies over the relationship between age and environmental consciousness. The first concerns the presence of cohort effects (Samdhal and Robertson, 1989; Gilg et al. 2005; Straughan and Roberts, 1999; Roberts, 1996b; Franzen and Meyer, 2009). The second is the possibility of life-cycle effects (Roberts, 1996b; Straughan and Roberts, 1999; Dychtwald \& Gable, 1990; Franzen and Meyer, 2009). Thirdly, there may be situational characteristics which alter the relationship (Diamantopoulos et al. 2003; Pinto et al. 2011), one of which could be the change or differences in social norms such as those associated with different countries.

Beginning with the cohort effect, it is known that studying the characteristics of cohorts can help identify patterns of behaviour amongst different age groups. A cohort is defined as "...groups of individuals who are born during the same time period and travel through life together. They experience similar external events during their late adolescent/early adulthood years" (Schewe and Meridith, 2004: p.51). 
Therefore cohorts reflect time specific events often in their formative years (Dychtwald \& Gable, 1990).

The influence of various cohorts on purchasing decisions have been argued to be significant. Hume (2009: p.387) for example, uses a review of previous studies to argue that "generational determined lifestyles and social values exercise as much influence on buying and purchasing as more commonly understood demographic factors like income, education, and gender do, perhaps even more". It is also claimed that a particular cohort can carry their consumption habits throughout an entire lifetime (Schewe and Meredith, 2004). For example, the depression-era cohort ("born from 1912-1921; came of age during the Great Depression; aged 83-92 in 2004”, (ibid: p. 54)) were raised during a period where resources needed to be carefully conserved, consumption was mostly frugal and they have predominantly maintained this ethos throughout their lives (ibid).

In contrast, the youngest generation surveyed in the 2009 Eurobarometer survey, are aged from teens to late twenties/early thirties. This "Y generation", born between 1978 and 1994 (Hume, 2009), came of age during the 'information revolution' (Schewe and Meredith, 2004), and have been brought up in a time when environmental issues are more salient ${ }^{10}$ than previous generations (Straughan and Robets, 1999). Ironically, this cohort is characterised as having high levels of credit (Buttner \& Grubler, 1995; Hume, 2009), being highly image conscious (Carrigan \& Attalla, 2001), indulging in excessive/conspicuous consumption, and focusing on swift career advancement (Hume, 2009).

There is a strong paradox in this generation. On the one hand they are "the most consumption orientated generation of all time due to the abundance and availability of products and services" (ibid: p.387). However they are also said to be the most socially aware generation (Hume, 2009; Roberts, 1996b; Buttner and Grubler, 1995; Autio and Heinonen, 2004; Schewe and Meredith, 2004). Apparently this young generation is not transforming their higher awareness of ethical issues into

\footnotetext{
${ }^{10}$ Global warming is one example of an environmental issue that has gained prominence in political and educational discussions alike in the last 10-20 years and thus has influenced the level of salience of environmental issues in general in the last few decades.
} 
environmentally conscious consumer behaviour (Buttner and Grubler, 1995; Autio and Heinonen, 2004). In a study of young persons' in Finland, Autio and Heinonen, (2004: p.145) use empirical evidence to show how "young people master the discourse of the green consumer, but are not willing to act accordingly" (Autio and Heinonen, 2004: p. 145).

The second main argument advanced for the age effect on environmentally conscious consumption is the life-cycle effect which refers to influences on behaviour being associated with reaching a certain stage of ones life (e.g., middle age, retired age). Using the example of the middle age years, (general consensus is ages 40-60) it is generally known that there are certain characteristics synonymous with this stage in life. For example, middle age is recognised as a period of self-assessment and review of one's life which can result in many changes of attitude (Dychtwald \& Gable, 1990). A common occurrence in middle age is to be more charitable than in youth (Roberts, 1996b; Straughan and Roberts, 1999; Dychtwald \& Gable, 1990). Research suggests that married persons with children living at home are more likely to put the needs of others' before their own needs (Laroche et al. 2001). Raising children can result in being more conscious about the future their children will inherit which can translate to an increased level of environmental concern (Pinto et al. 2011). Parents are seen to more likely to be ecologically conscious and spend more on green product choices (Laroche et al. 2001).

A third possible reason for observed age effects are situational or context effects. According to this argument social norms and/or characteristics of the physical environment might coincide with a cohort or the stage of one's life (Pinto et al. 2011). Diamantopoulos et al. (2003: p.477) describe, “...environmental consciousness is perhaps more a function of situational characteristics...those who are at risk from environmental nuisances, such as air pollution, contamination of water supplies, or the detrimental impacts of new road developments, are more likely to be knowledgeable and feel strongly about such issues, and, consequently, more likely to campaign against their effects". To the extent that theses might coincide with living in a particular country or in a neighbourhood which also has age determinants then they can indirectly be reflected in age effects. 
Assessing the influence that individual variables such as age have on environmental concern is often difficult because of the close relationship age has with several other influential factors such as education. For example, Freymeyer and Johnson (2010: p.186-187) describe their predicted relationship between age and education:

"Age's influence often interacts with education to shape views on environmental and other social issues: Younger people complete more education, and increased education contributes to increased environmental concern..."

What follows is a brief summary of the findings of previous studies regarding the control variables I will be using in my analysis.

\subsection{Gender}

In contrast to age, testing for gender has been a lot more explicit in the literature. The vast majority of studies show that females are more likely to be environmentally conscious. Of fifty-one studies covered in Table 2.1, twenty-four produced statistically significant results. Of those twenty-four studies, twenty found woman to be more environmentally conscious than men and only four studies found in favour of men. This represents a ratio of 5:1 in favour of woman. One theory as to why this might be the case is that woman are more inclined towards caring and nurturing (Autio et al. 2009), and are generally more aware than men of how actions affect others' (Roberts, 1996b).

In separating treatment of environmental knowledge, attitudes and behaviour, the literature has found that men tend to display a higher level of knowledge/awareness of environmental problems than woman (Meffert and Bruhn, 1996; Schan and Holzer, 1990). However both Diamantopoulos et al. (2003) and Jain and Kaur (2008) failed to demonstrate statistically significant results in support of this hypothesis. With respect to environmental attitudes and behaviour, most tend to show that females are more likely to be greener consumers (e.g., Lee, 2008; 2009; Autio and Heinonen, 2004; Roberts, 1996b; Manineiri, 2010; Jain and Kaur, 2008; Shen and Saijo, 2008). As well as gender, education level has been frequently included in the literature and is a 
key inclusion in understanding the characteristics of green consumers.

\subsection{Education Level}

Higher education has consistently been shown to broaden environmental knowledge which in turn "correlates positively with environmental attitudes, behaviours and participation" (Haron et al. 2005, p.435). Results for educational level in the studies reviewed suggest that those who continued their education to a higher level are more likely to be green consumers. There are two exceptions to this consensus however. Samdhahl and Robertson (1989) show that those reporting lower education levels tend to be greener and could not find a convincing explanation for this outcome. Pinto et al (2011) found Brazilian citizens who were less educated were more likely to approach water consumption more sustainably than their higher educated counterparts. The authors' explanation of this result is that lower educated persons are likely to have lower incomes and be more aware of water costs. Closely related with education, social class has been examined in many studies and I assess the results as follows.

\subsection{Social class (Occupation and Income)}

Occupation and income are two further variables that might also confound the influence of age. Together they are sometimes referred to as social class. In the early days of research identifying characteristics of the environmentally concerned consumer, occupation was more frequently included in studies than today. For example, Anderson and Cunningham, (1972), and Tognacci et al. (1972) found that occupation was a key discriminate of environmentally conscious consumption, where as Kinnear et al. (1974) and Webster (1975) did not find any strong evidence of such a relationship.

With the exception of Anderson and Cunningham, (1972) - the above studies concluded income to be a significant predictor of green consumption and that those with higher incomes tend to be more environmentally conscious. Since the 1970s, the 
majority of studies have supported the prediction that higher income earners are more likely to be green consumers (e.g., Roper Organization, 1992; Zimmer et al. 1994; Shen and Saijo, 2008; Jain and Kaur, 2008; Chan 2000; Franzen and Meyer, 2009). As there is no data on income collected in the 2009 Eurobarometer survey occupation and education must serve as proxies for the positive income effect.

Few studies in recent years have tested for occupation per se. Perhaps the reasoning behind this is that high or low incomes can denote high or low occupations, and thus for the most part, the variables are correlated. For example, Jain and Kaur (2008: p.116) suggested that "occupation is a sort of composite variable that manifests differences present among the persons in terms of their income, educational level and social sophistication."

My examination of the literature shows that over half of studies in table 2.1 did include occupation. Of those that did, fourteen studies found occupation not to be significant, ten found a positive relationships in favour of higher occupations (for example doctor, lawyer, general manger), two studies gave mixed results (Jain and Kaur, 2008; Chan 2000) and there were no studies showing a negative relationship between occupation and environmental consciousness.

Some examples of results for occupation in recent years include Finisterra do Paço and Raposo (2010: p.435), who found those with "more qualified jobs (middle and senior management and specialists from the intellectual, scientific and artistic occupations)" were more likely to fit the green consumer profile mould than those in less qualified occupations. Alibeli and Johnson (2009) discovered the middle class were more likely to buy green products than the working class. Some studies demonstrated that the occupations listed as being associated with higher levels of green consumer consciousness were a mixture of 'higher' and 'lower' occupations. For example, Jain and Kaur (2008) showed that housewives, professionals and service class persons showed the greatest level of environmental consciousness. Chan (2000) discerned that managers, professionals and students were likely to choose green products in their purchases over the unemployed, retired as well as housewives. 
The results of Jain and Kaur (2008) and Chan (2000) suggested that those with both 'higher' and 'lower' occupations can be equally regarded in terms of green consumer consciousness. Furthermore, two of the occupations listed, students (Chan, 2000) and housewives (Jain and Kaur, (2008)) are not positions of employment per se. The various locations a person might live can influence which occupation they are likely to have (for example, farmers will likely live in rural areas, office workers will likely live in urban areas) and I explore this 'context' variable in relation to the literature as follows:

\subsection{Residence (urban vs. rural)}

My literature review shows that urban or rural residence was a variable least commonly included in various studies and this is highlighted by the fact that $70 \%$ of studies reviewed did not test whether green consumers are more likely to reside in rural or urban areas. More frequently examined in the 1980s and 1990s, only four studies included the residence variable post-2000. One explanation for this is due to the increasing levels of urbanization throughout the world (Aydin and Çepni, 2010). The majority of people now living in urban areas far outweighs the number of rural residents.

Table 2.1 shows that out of thirteen studies which found a statistically significant relationship between residence and environmental concern, ten studies gave a positive (urban) result (Tremblay and Dunlap, 1977; Lowe and Pinhey, 1982; Van Liere and Dunlap, 1980; Samdhal and Robertson, 1989; Arcury and Christianson 1990; Roper Organization, 1992; Jones and Dunlap 1992; Zimmer et al 1994; Berger, 1997; Shen and Saijo 2008). This finding is consistent with the literature review conducted by Straughan and Roberts (1999), who found six of seven studies found urban residents were more likely to be green consumers.

Only two studies in my review gave findings in favour of rural residents as more environmentally concerned. Balderjahn (1988) found that rural residences are more likely to choose pro-environmental home insulation products than urban residents. 
Berenguer et al. (2005: p.128) concluded that "People living in the rural context present more attitudes of environmental responsibility" and that it is "those living in the rural environment that have a more well-developed sense of moral obligation to care for the environment, and that behave more responsibly" (ibid, p. 135).

Instead of the rural-urban divide, Nevitte and Kanji (1995) found distinctions based on resource extractive vs. manufacturing parts of the country as well as an East-West geographic divide within Canada. It was seen that Western Canada and resource extractive regions are more aware of environmental issues in their study. Although there were more studies in favour of green consumers residing in urban regions than rural ones, overall out of fifty studies there were only thirteen results which achieved statistical significance. The influence of residence on environmental consciousness now leads me to discuss how spatial variations on a cross-country level have a similar effect and I discuss this in the next subchapter.

\subsection{Cross-country analysis}

The majority of studies which conduct analysis in environmental concern focus on one or two countries (see 'survey place' column in Table 2.1) Studies which compare environmental consciousness across a larger group of (say, more than a dozen) countries are fewer in number. In this regard, Schultz and Zelezny (1999: p.264) note how:

“...very little multinational environmental research is being conducted...We believe that a multinational understanding of the values and motives that underlie environmental concern and behavior is needed before we can move toward more effective environmental policies and social interventions designed to increase pro-environmental behavior."

Some studies that have conducted cross-country analysis in relation to environmental consciousness over a wide variety of countries include for example, Hunter et al. (2004), Marquart-Pyatt, (2008), Franzen and Meyer, (2009), and Freymeyer and Johnson, (2010).

Considerable debate amongst researchers surrounds the relationship between national 
wealth and environmental concern. Inglehart (1995) puts forward the hypothesis that increased environmental concern occurs within a country as it develops economically (also Franzen and Meyer, 2009; Shultz and Zelezny 1999). The theory holds that the more developed a society is, the greater the degree of freedom to engage in 'postmaterialistic' goals such as environmental preservation Inglehart (1995: p.57) describes his theory as follows;

“...within given countries, people with "Postmaterialist" values emphasizing self-expression and the quality of life are much more apt to give high priority to protecting the environment (and are much more likely to be active members of environmentalist groups), than those with "Materialist" values emphasizing economic and physical security above all..."

To support the 'materialist' priorities of developing countries, Jain and Kaur, (2004) note how developing countries are more likely to focus on improving the basic essentials of life and therefore give less attention to environmental issues. Freymeyer and Johnson (2010) point out that many developing countries simply cannot afford the necessary action to protect the environment and therefore that a nation's economic situation has a more significant effect on environmental concern than a nation's environmental situation. In their study, those living in more wealthy countries were more likely to be active in environmental groups both through time and money than in poorer countries. This is consistent with Inglehart's (1995) postmaterialist theory that pro-environmental behaviour is more likely to occur once the basic necessities of life are met.

Franzen and Meyer, (2009) hypothesise that the demand for environmental quality increases with increasing wealth as high income earners engage more frequently in leisure activities in a natural setting (for example, sailing on the ocean, skiing or hiking in the mountains). As more inhabitants of a country increase individual wealth, this increases the overall wealth of the nation which in turn can affect the relationship between national wealth and environmental concern (ibid). Figure 2.1 shows the relationship between national wealth and environmental consciousness. The correlation of $\mathrm{r}=0.80$ shows a positive relationship between GDP per capita and environmental concern. 
Figure 2.1: Graph showing the relationship between environmental concern in selected countries and GDP per capita (PPP), 2010.

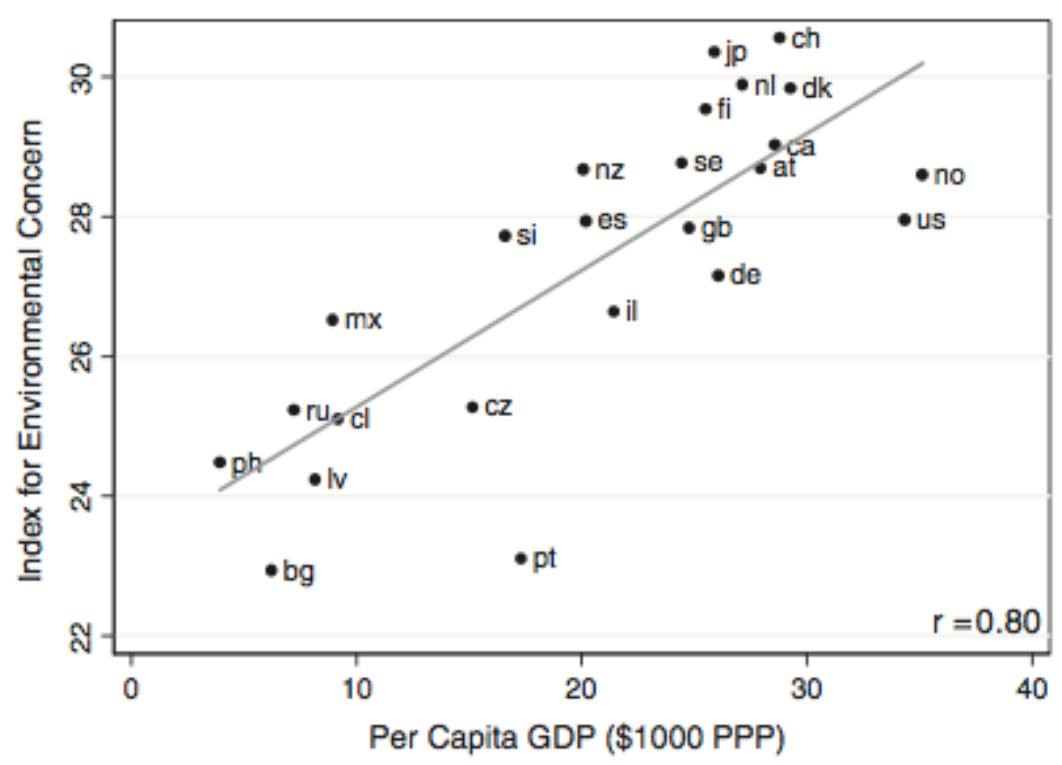

Source: Franzen and Meyer (2009: p.226)

Key to Countries: Switzerland (ch), Japan (jp), Netherlands (nl), Denmark (dk), Finland (fi), Canada (ca), Sweden (se), Austria (at), New Zealand (nz), Norway (no), Ireland (ie), USA (us), Spain (es), Great Britain (gb), Slovenia (si), Germany (de), Israel (il), Mexico (mx), Russia (ru), Czech Republic (cz), Chile (cl), Philippines (ph), Latvia (lv), Portugal (pt), Bulgaria (bg).

Not all authors agree though that wealthier countries exhibit higher levels of environmental consciousness. For example, Dunlap and Mertig (1995) suggest that increased levels of environmental concern in various countries is not in fact a result of some countries becoming wealthier per se, but of increased attention to environmental issues on a global scale. Schultz and Zelezny (1999) discovered that respondents from Spanish speaking countries in South and Central America showed consistently higher levels of environmental consciousness than respondents from the USA. This result is opposes the postmaterialist hypothesis of Inglehart (1995).

Similarly, in their study of Indian citizens, Jain and Kaur (2004) find contrary results to the widely held belief that developed countries are more environmentally proactive. National Geographic Online (2010) rates countries across the world via a 'Greendex' Index of combined environmental indicators. Their findings for 2010 showed India and Brazil at the top of the Greendex rankings, with emerging economies constituting the top six countries. The USA and Canada ranked the lowest with the other four lowest countries being industrialized countries. 
Figure 2.2: Graph showing the relationship between environmental concern in selected countries and $\mathrm{CO}_{2}$ emissions per unit of GDP, $2010 .^{11}$

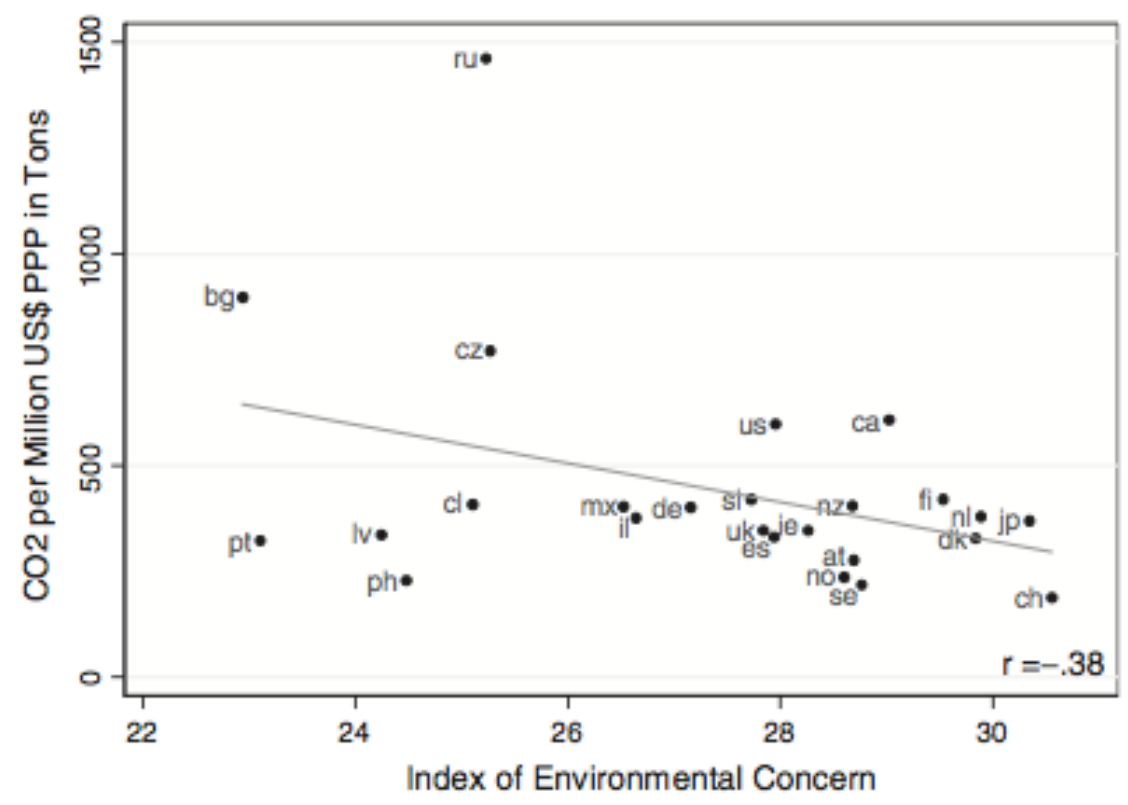

Source: Franzen and Meyer (2009: p.230)

Key to Countries: Switzerland (ch), Japan (jp), Netherlands (nl), Denmark (dk), Finland (fi), Canada (ca), Sweden (se), Austria (at), New Zealand (nz), Norway (no), Ireland (ie), USA (us), Spain (es), Great Britain (gb), Slovenia (si), Germany (de), Israel (il), Mexico (mx), Russia (ru), Czech Republic (cz), Chile (cl), Philippines (ph), Latvia (lv), Portugal (pt), Bulgaria (bg).

Another example is demonstrated in Figure 2.2 where Franzen and Meyer (2009) plot the regression line between $\mathrm{CO}^{2}$ emissions and index of environmental concern for selected countries. The correlation is $r=-.38$ which demonstrates a negative relationship between $\mathrm{CO}^{2}$ emissions and environmental concern. The countries with the highest levels of environmental concern not only have lower levels of $\mathrm{CO}^{2}$ emissions but are also high socio-economic countries such as Switzerland, Japan, Denmark and The Netherlands. However from another perspective, several studies show respondents from countries with the most serious environmental problems are more likely to develop high levels of environmental concern (Marquart-Pyatt, 2007; Freymeyer and Johnson, 2010). For example, Freymeyer and Johnson, 2010 predicted that countries with tangible environmental problems such as air and water pollution (eg., Russia, Turkey, and Czech Republic) are more likely to rate higher for

\footnotetext{
${ }^{11}$ Key to Countries: Switzerland (ch), Japan (jp), Netherlands (nl), Denmark (dk), Finland (fi), Canada (ca), Sweden (se), Austria (at), New Zealand (nz), Norway (no), Ireland (ie), USA (us), Spain (es), Great Britain (gb), Slovenia (si), Germany (de), Israel (il), Mexico (mx), Russia (ru), Czech Republic (cz), Chile (cl), Philippines (ph), Latvia (lv), Portugal (pt), Bulgaria (bg).
} 
environmental concern.

Alibeli and Johnson (2009) conducted research in Saudi Arabia, Bahrain, Jordon and Qatar and results showed that Jordanians displayed higher levels of environmental concern than in the other three countries. The authors' give two plausible explanations for their result; firstly, Bahrain, Saudi Arabia and Qatar are geographically situated in dry, arid and harsh desert regions and "controlling the environment is widely seen as a critical survival mechanism" (ibid, 7). Secondly, those countries are big oil producers and as such are particularly concerned that environmental issues may threaten oilbased economic prosperity (ibid). This example serves to illustrate how different situational characteristics across different countries can influence environmental consciousness.

\subsection{Summary}

My review of the literature highlights several main points. Firstly, there are conflicting results in previous studies as to how age influences environmental consciousness and this might be due to a lack of appreciation of the non-linearity of the relationship. Secondly, several factors might influence environmental consciousness at various ages including cohort effects, life-cycle effects, and the choice of location at different ages might also be a factor. This brings me to my third point: living in a certain country, or region within a country, might influence the relationship between age and environmental consciousness. My final point from the literature review is that there are several other key variables such as education level and occupation that might influence the degree to which age influences environmental concern.

My attention now turns to my methodology how I will describe the demography of the green consumer, how attitudes vary by age and how this relationship varies by country within the EU. 


\section{Chapter 3. Methodology}

The aim of my study is to examine the relationships between age and environmental consciousness in relation to the products people buy. However the literature showed evidence of conflicting and confounding results in establishing the link between age and environmental consciousness in consumption. In order to control for possible confounding effects a suitable data set had not only to cover a range of measures on respondents attitudes, but sample across countries and do so with sufficient observations to ensure statistical tests had the requisite power. These requirements ruled out constructing a survey of my own.

A search for a dataset that matches the above criteria for New Zealand alone proved fruitless. In the Quality of Life survey, for example there are some questions relation to environmental issues, but none of those questions relate directly towards sustainable consumption of products people buy. Similarly, the World Values Survey 2010-2012 includes New Zealand but once again, the questions did not include specific questions related to environmentally conscious consumption of products people buy.

It was clear that I needed to extend my search for a suitable data set at a global level. The result was the 2009 Flash Eurobarometer survey entitled 'European's attitudes towards the issue of sustainable consumption and production'. ${ }^{12}$ Its aim was "to examine EU citizen's knowledge and level of concern about sustainable consumption and production.” (The Gallup Organisation, 2009: p.4).

This survey manages to avoid a lot of the problems that have been identified in previous research (see Diamantopoulos et al. 2003). Firstly, the survey collection method was uniform over all countries. Secondly, instead of a specific focus on a particular green product, the survey tested for attitudes towards sustainable consumption of products consumers buy in general. Thirdly, the data was recently collected in 2009 so is up to date with current trends in green consumer

\footnotetext{
${ }^{12}$ To my knowledge there have been no published studies using the 2009 Eurobarometer survey data apart from the Gallup Poll's own summary (The Gallup Organisation, 2009).
} 
consciousness. Lastly, the number of observations was sizeable $(n=26,642)$ which increases the likelihood of statistically significant results in the modelling.

\subsection{Survey}

The Flash Eurobarometer Survey (No. 256) was conducted in Europe in 2009 by The Gallup Organisation, Hungary, upon the request of European Commission Directorate General Environment co-ordinated by EC Directorate General Communication. ${ }^{13}$ The questionnaire is reproduced as Appendix 1.

The survey aimed to assess European attitudes towards sustainable consumption of products by asking respondents to answer a series of questions related to their consumption of products. Whilst not all questions specifically relate to environmental issues, the underlying objective of the survey was to gauge the level of support for initiatives aimed at improving environmental sustainability.

Telephone interviews were conducted in each of the 28 countries listed below, with the exception of the Bulgaria, Czech Republic, Estonia, Latvia, Lithuania, Hungary, Poland, Romania and Slovakia where both telephone and face-to-face interviews were conducted (70\% telephone and $30 \%$ face to face interviews). Telephone interviews were conducted in each country between the 21/04/2009 and the 25/04/2009 using a range of different institutes who translated the original English questionnaire into their respective national language(s). Average length of interview was recorded as just over 9 minutes reflecting the tight focus of the survey.

In most EU countries and Croatia the target sample size was 1000 respondents, except Malta, Cyprus and Luxembourg where the target size was 500 interviews. A

\footnotetext{
${ }^{13}$ The data were provided free on request from the GESIS (Leibniz Institute for the Social Sciences, Cologne) Archive Study (ID: ZA4983, Flash Eurobarometer 258, April 2009). See http://www.gesis.org/eurobarometer/. The data set was provided on the understanding that the depositors, institutes nor GESIS bear any responsibility for the analysis or interpretation of the data. Users have a responsibility to inform the Data Archive about the completion of the project for which their material was used. Typically the user must destroy the data after the project has been completed. Two copies are required using designated citation formats. Original case identifiers were replaced by a serial case id appointed by the archive.
} 
weighting factor was applied to the national results in order to compute a marginal total where each country contributes to the European Union result in proportion to its population (see Appendix 2 for details). The 2009 Eurobarometer survey was administered to samples in 28 countries (EU27 and Croatia). They are listed in Table 3.1 along with the weighting scales, and the observations below.

Table 3.1: List of countries used in the 2009 Eurobarometer Survey and the EU27 weightings.

\begin{tabular}{|l|l|l|l|l|}
\hline Country & Observations & \% of total & $\begin{array}{l}\text { EU27 } \\
\text { weighted }\end{array}$ & $\begin{array}{l}\text { \% of Total } \\
\text { (weighted) }\end{array}$ \\
\hline Germany & 1010 & 3.8 & 4357 & 17.0 \\
\hline France & 1006 & 3.8 & 3174 & 12.4 \\
\hline Italy & 1011 & 3.8 & 3124 & 12.2 \\
\hline United Kingdom & 1001 & 3.8 & 3083 & 12.0 \\
\hline Spain & 1002 & 3.8 & 2337 & 9.1 \\
\hline Poland & 1005 & 3.8 & 1974 & 7.7 \\
\hline Romania & 1009 & 3.8 & 1122 & 4.4 \\
\hline The Netherlands & 1010 & 3.8 & 824 & 3.2 \\
\hline Greece & 1004 & 3.8 & 589 & 2.3 \\
\hline Belgium & 1003 & 3.8 & 540 & 2.1 \\
\hline Czech Republic & 1002 & 3.8 & 542 & 2.1 \\
\hline Portugal & 1009 & 3.8 & 551 & 2.1 \\
\hline Hungary & 1007 & 3.8 & 525 & 2.0 \\
\hline Sweden & 1000 & 3.8 & 465 & 1.8 \\
\hline Austria & 1002 & 3.8 & 431 & 1.7 \\
\hline Bulgaria & 1004 & 3.8 & 409 & 1.6 \\
\hline Denmark & 1000 & 3.8 & 273 & 1.1 \\
\hline Slovakia & 1007 & 3.8 & 278 & 1.1 \\
\hline Finland & 1000 & 3.8 & 269 & 1.0 \\
\hline Ireland & 1003 & 3.8 & 211 & 0.8 \\
\hline Lithuania & 1005 & 3.8 & 175 & 0.7 \\
\hline Latvia & 1005 & 3.8 & 121 & 0.5 \\
\hline Slovenia & 1005 & 3.8 & 106 & 0.4 \\
\hline Estonia & 1015 & 3.8 & 70 & 0.3 \\
\hline Cyprus & 501 & 1.9 & 39 & 0.2 \\
\hline Luxembourg & 504 & 1.9 & 24 & 0.1 \\
\hline Malta & 503 & 1.9 & 21 & 0.1 \\
\hline Croatia & 1009 & 3.8 & - & - \\
\hline TOTAL & 26,642 & 100 & 25,633 & 100 \\
\hline & & & & \\
\hline
\end{tabular}

Source: Eurobarometer 2009, p. 80

\subsection{Dependent Variables}

Although the 2009 Eurobarometer report included thirteen questions in total (listed in Appendix 1), I only analyse six of these. There are two main reasons I am selecting these questions. Firstly, the questions provide response options in such a way that 
people are either more pro-environmentally inclined, or less so. Secondly, my selected questions deal most directly with both awareness and concern of the environmental impact of products people buy (questions 1 and 2a) as well as several policy initiatives that aim at improving environmentally responsible consumption (questions 3,5,9 and 13). These six questions constitute the dependent variables which relate to environmental consciousness and are listed as follows along with the response options.

Question 1: In general, how much do you know about the environmental impact of the products you buy and use?

- I am fully aware 4

- I know about the most significant impacts.................................................... 3

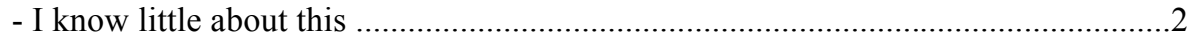

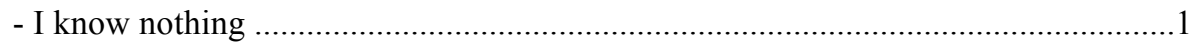

Question 2: How important are the following aspects when making a decision on what products to buy?

a) The product's impact on the environment.

- Very important....................................... 4

- Rather important .................................... 3

- Rather not important .............................. 2

- Not at all important............................... 1

Question 3: Some products have an ecolabel which certifies that they are environmentally-friendly. Which statement characterises you the best?

- Ecolabelling plays an important part in my purchasing decisions ...............................

- Ecolabelling does not play an important part in my purchasing decisions ..................... 2

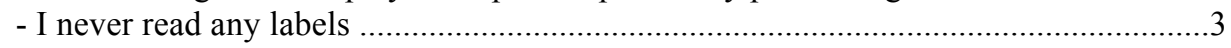

Question 5: Should a label indicating the carbon footprint of a product be mandatory in the future?

- Yes .1

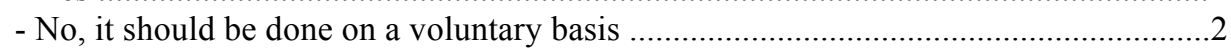

- The carbon footprint is of no interest to me .............................................................. 3

Question 9: Are you aware of the flower, the symbol of the EU ecolabel?

- I've seen it or heard it and I have bought products with this label...............................

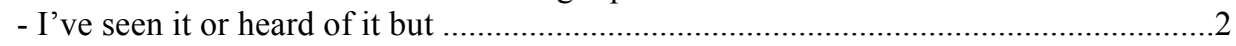

- The carbon footprint is of no interest to me ........................................................... 
Question 13: It has been proposed by the EU that retailers develop a voluntary environmental code of conduct. Which opinion is closer to your view?

- It is better to use binding legislation than a voluntary code of conduct $\ldots 1$

- Retailers are already doing a lot for the environment and a voluntary code of conduct is not needed

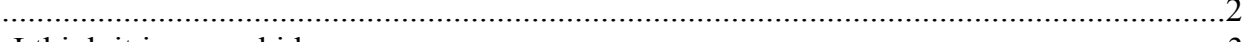

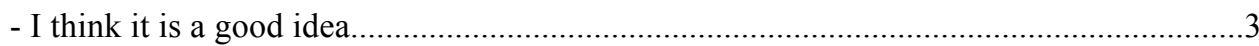

These selected questions represent the dependent variables, however there are some limitations related to the representation of the European populous. For example, as will be shown, the age distribution of respondents is skewed towards older persons in comparison to the EU age distribution and therefore is likely to be biased towards the characteristics of older cohorts. An example is that retired persons are less likely to purchase a large amount of items on a day to day basis in comparison to say, middle aged persons raising a family, so might be less aware of such environmental initiatives as ecolables or environmental codes of conduct. As age is the independent variable I examine in the most detail, I now discuss the methodology in which I plan to use this variable in my analysis.

\subsection{Age and Age $^{2}$}

My aim is to examine the relationship between age and environmental consciousness. I found, in exploratory work, that this relationship was non-linear, that environmental consciousness related to products bought follows an inverted $U$ shape with respect to age as predicted by Franzen and Meyer (2009). I represent the non-linear by expressing the age relationship as a quadratic. A positive result for age and a negative result for age ${ }^{2}$ is indicative of the inverted $U$ shape relationship. In the multivariate models variables are centred in order to avoid the strong correlation between age and age $^{2}$.

The basic equation I estimate is as follows

$y_{i}^{m}=\alpha+\beta_{1} \operatorname{Cage}_{i}+\beta_{2} \operatorname{Cage}_{i}^{2}+\beta_{k} X_{i}+\varepsilon_{i}$

Where $y_{i}$ is the response to the $m^{\text {th }}$ question, $(m=1, \ldots 5)$ by the $i^{\text {th }}$ respondent, Cage is the centred measure of the respondents age, $\mathrm{Cage}^{2}$ is the centred squared value of age. 
$X$ is a vector of control variables (gender, education, occupation and residence as covered above). The parameters are $\alpha$ the intercept, $\beta_{1}$ and $\beta_{2}$ the influence of Cage and $\mathrm{Cage}^{2}$ on $y_{i}$. The parameters $\beta_{k}$ indicated the influence the controls have on the response variable and $\varepsilon_{i}$ is the error term. The distribution of the error term depends on how we measure $y_{i}$.

Question 1 and 2a asked by the 2009 Gallup Poll elicit ordered responses such that $4>3>2>1$. The influence of the above arguments on such variables are typically estimated in an ordinal logit model. The parameters reflect the arguments affect on a latent variable running from 1 through 4 . In practice the parameter estimates are very similar to those obtained when responses to question 1 and $2 \mathrm{a}$ are treated as continuous variables and estimated using ordinary lease squares (OLS) (Ferrer-iCarbonell and Frijters, 2004). Both ordinal logit and OLS estimates are shown for these first two questions and then OLS is used for subsequent models with no loss of rigour.

Questions 3, 5, 9 and 13 are recoded as binary variables and estimated in logit regression models. In the ecolabelling case for example (Question 3), response $1=1$ and response 2 and 3 are set to 0 . The exponent of the estimated parameters are the odds ratios in favour of the positive response. The same transformation of the 1,0 response to the logs of the odds ratio (the logit) is undertaken for the remaining questions (Hamilton, 2009).

\subsection{Control Variables}

The relationship between age and environmental consciousness may not be independent of several other characteristics of consumers. Therefore it is desirable to control for these. Age, age ${ }^{2}$ and the control variables (related to gender, education, occupation and population density) are tabulated in Table 3.2 below. 
Table 3.2: Descriptive statistics of the independent variables ${ }^{\dagger}$

\begin{tabular}{|c|c|c|c|c|c|}
\hline Variable | & obs & Mean & Std. Dev. & Min & $\operatorname{Max}$ \\
\hline $\begin{array}{l}\text { age } \\
\text { age2 }\end{array}$ & $\begin{array}{l}26389 \\
26389\end{array}$ & $\begin{array}{l}50.05188 \\
2805.495\end{array}$ & $\begin{array}{l}17.32962 \\
1730.725\end{array}$ & $\begin{array}{r}15 \\
225\end{array}$ & $\begin{array}{r}99 \\
9801\end{array}$ \\
\hline male | & 26389 & .3740195 & .4838779 & 0 & 1 \\
\hline $\begin{array}{r}\text { EDUCATION } \\
\text { No_fu11_time } \\
\text { Less_than_15 } \\
\text { Age_16_20 } \\
\text { Age_20p7us } \\
\text { Sti11_in_edu } \\
\text { Refusal }\end{array}$ & $\begin{array}{l}26389 \\
26389 \\
26389 \\
26389 \\
26389 \\
26389\end{array}$ & $\begin{array}{l}.0155747 \\
.1371026 \\
.4358255 \\
.3243018 \\
.0744628 \\
.0127326\end{array}$ & $\begin{array}{l}.1238252 \\
.3439621 \\
.4958739 \\
.4681223 \\
.2625276 \\
.1121202\end{array}$ & $\begin{array}{l}0 \\
0 \\
0 \\
0 \\
0 \\
0\end{array}$ & $\begin{array}{l}1 \\
1 \\
1 \\
1 \\
1 \\
1\end{array}$ \\
\hline $\begin{array}{l}\text { OCCUPATION } \\
\text { Professional } \\
\text { Executive } \\
\text { Middle_manag } \\
\text { Owner_manage } \\
\text { Manua1_worke } \\
\text { Home_maker } \\
\text { Student } \\
\text { Retired } \\
\text { Job_seeker } \\
\text { Other_refu d }\end{array}$ & $\begin{array}{l}26389 \\
26389 \\
26389 \\
26389 \\
26389 \\
26389 \\
26389 \\
26389 \\
26389 \\
26389\end{array}$ & $\begin{array}{r}.0770776 \\
.0293683 \\
.0981091 \\
.221077 \\
.0617303 \\
.073705 \\
.0695365 \\
.3118724 \\
.0356588 \\
.0218652\end{array}$ & $\begin{array}{l}.2667195 \\
.1688398 \\
.2974677 \\
.4149801 \\
.2406696 \\
.2612951 \\
.2543692 \\
.4632668 \\
.1854415 \\
.146246\end{array}$ & $\begin{array}{l}0 \\
0 \\
0 \\
0 \\
0 \\
0 \\
0 \\
0 \\
0 \\
0\end{array}$ & $\begin{array}{l}1 \\
1 \\
1 \\
1 \\
1 \\
1 \\
1 \\
1 \\
1 \\
1\end{array}$ \\
\hline $\begin{array}{c}\text { RESIDENCE } \\
\text { metro } \\
\text { urban } \\
\text { rura } 1\end{array}$ & $\begin{array}{l}26389 \\
26389 \\
26389\end{array}$ & $\begin{array}{l}.1983402 \\
.6417068 \\
.3582932\end{array}$ & $\begin{array}{r}.3987573 \\
.479508 \\
.479508\end{array}$ & $\begin{array}{l}0 \\
0 \\
0\end{array}$ & $\begin{array}{l}1 \\
1 \\
1\end{array}$ \\
\hline
\end{tabular}

Source: Eurobarometer Survey, 2009

I include gender in the analysis mainly because it is one of the most commonly used demographic variables in green consumer profile studies and the results with the previous literature may be useful. At the same time I do know that females were overrepresented in the 2009 Eurobarometer survey, representing 62.7\% of total observations.

Education level is an important control because it has been shown repeatedly to affect environmental consciousness and has distinct relationships with age. Table 3.3 shows the distribution of the sample across education levels.

\footnotetext{
${ }^{\dagger}$ The total number of observations in the survey is 26,642 , however I have only used those observations where the respondents age was given and was above 15 years $(n=26,389)$. So effectively I have lost 253 observations.
} 
Table 3.3: 2009 Eurobarometer survey responses by education level (EU27 and Croatia combined).

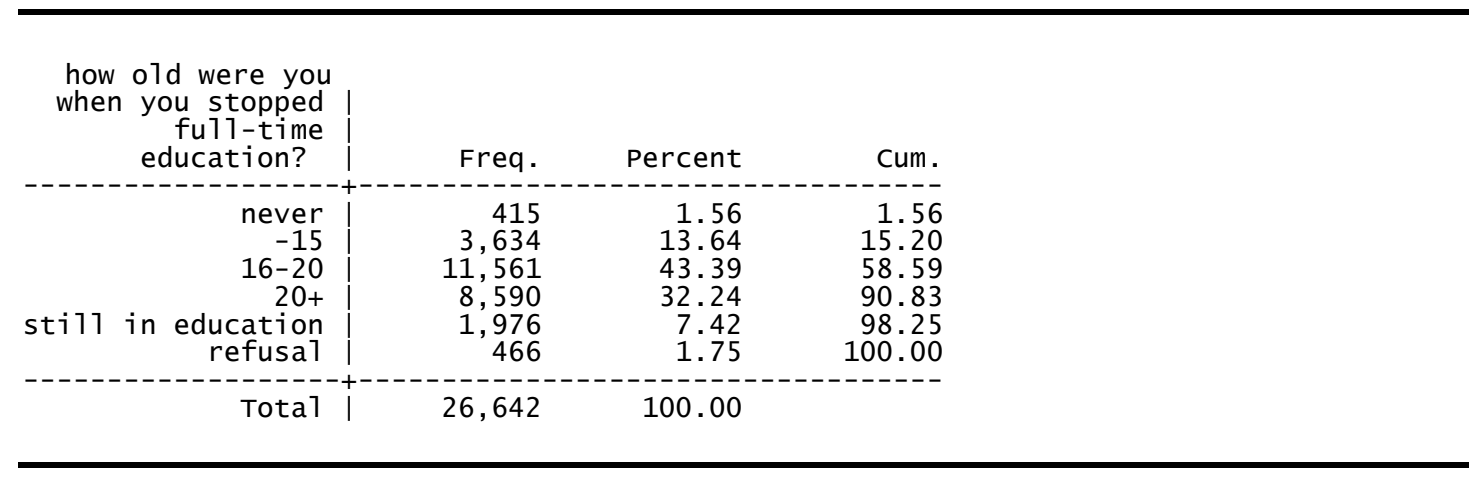

Source: Eurobarometer, 2009

As table 3.2 shows, the responses to education are weighted toward those who finished full-time education between the ages 16-20 (43\% of all observations) and above 20 years old (32\% of total). Together they account for $75 \%$ of all respondents. On average, a respondent studied full time until around the age of 19 and a half. Those that are finishing their full time education above the age of 20 diminishes by age as Figure 3.1 shows.

Table 3.4: Cross tabulation of the 2009 Eurobarometer survey responses by education level and age group (EU27 and Croatia combined).

\begin{tabular}{|c|c|c|c|c|c|c|c|}
\hline $\begin{array}{l}\text { how old } \\
\text { are you? }\end{array}$ & $\begin{array}{c}\text { how } \\
\text { never }\end{array}$ & $\begin{array}{c}\text { re you } \\
-15\end{array}$ & $\begin{array}{l}\text { when you } \\
16-20\end{array}$ & ed $\begin{array}{l}\mathrm{fu} 11 \\
20+\end{array}$ & $\begin{array}{l}\text { time educ } \\
\text { sti11 in }\end{array}$ & $\begin{array}{l}\text { ation? } \\
\text { refusal }\end{array}$ & Tota1 \\
\hline $\begin{array}{r}15-24 \\
25-39 \\
40-54 \\
55+ \\
\mathrm{dk} / \mathrm{na}\end{array}$ & $\begin{array}{l}1.45 \\
0.45 \\
0.84 \\
2.54 \\
1.58\end{array}$ & $\begin{array}{r}1.74 \\
4.65 \\
8.80 \\
23.61 \\
6.32\end{array}$ & $\begin{array}{l}22.70 \\
46.37 \\
50.80 \\
42.14 \\
23.72\end{array}$ & $\begin{array}{r}6.30 \\
43.36 \\
38.10 \\
29.50 \\
12.65\end{array}$ & $\begin{array}{r}67.45 \\
4.46 \\
0.63 \\
0.18 \\
4.35\end{array}$ & $\begin{array}{r}0.36 \\
0.71 \\
0.82 \\
2.03 \\
51.38\end{array}$ & $\begin{array}{l}100.00 \\
100.00 \\
100.00 \\
100.00 \\
100.00\end{array}$ \\
\hline Total & 1.56 & 13.64 & 43.39 & 32.24 & 7.42 & 1.75 & 100.00 \\
\hline
\end{tabular}

Source: Eurobarometer, 2009, Values are percentages.

From Table 3.4 note that those in the oldest age bracket (55+) were less likely to have studied at a higher education level (29.5\% of respondents in this category) than younger age groups such as the 40-54 group (38.10\% gained higher education) and the 25-39 group (43.36\%). Similarly, the over 55 year olds were more than twice as likely to have finished full time education under the age of 15 compared to the 40-54 age bracket and over five times more likely than the 25-39 age group. In my analysis I 
construct six dummy variables based on education level segmentation used in the survey and are shown in Table 3.5

Figure 3.1: Scatter graph showing the age when full-time education finished and age of the respondent. The 2009 Eurobarometer survey."

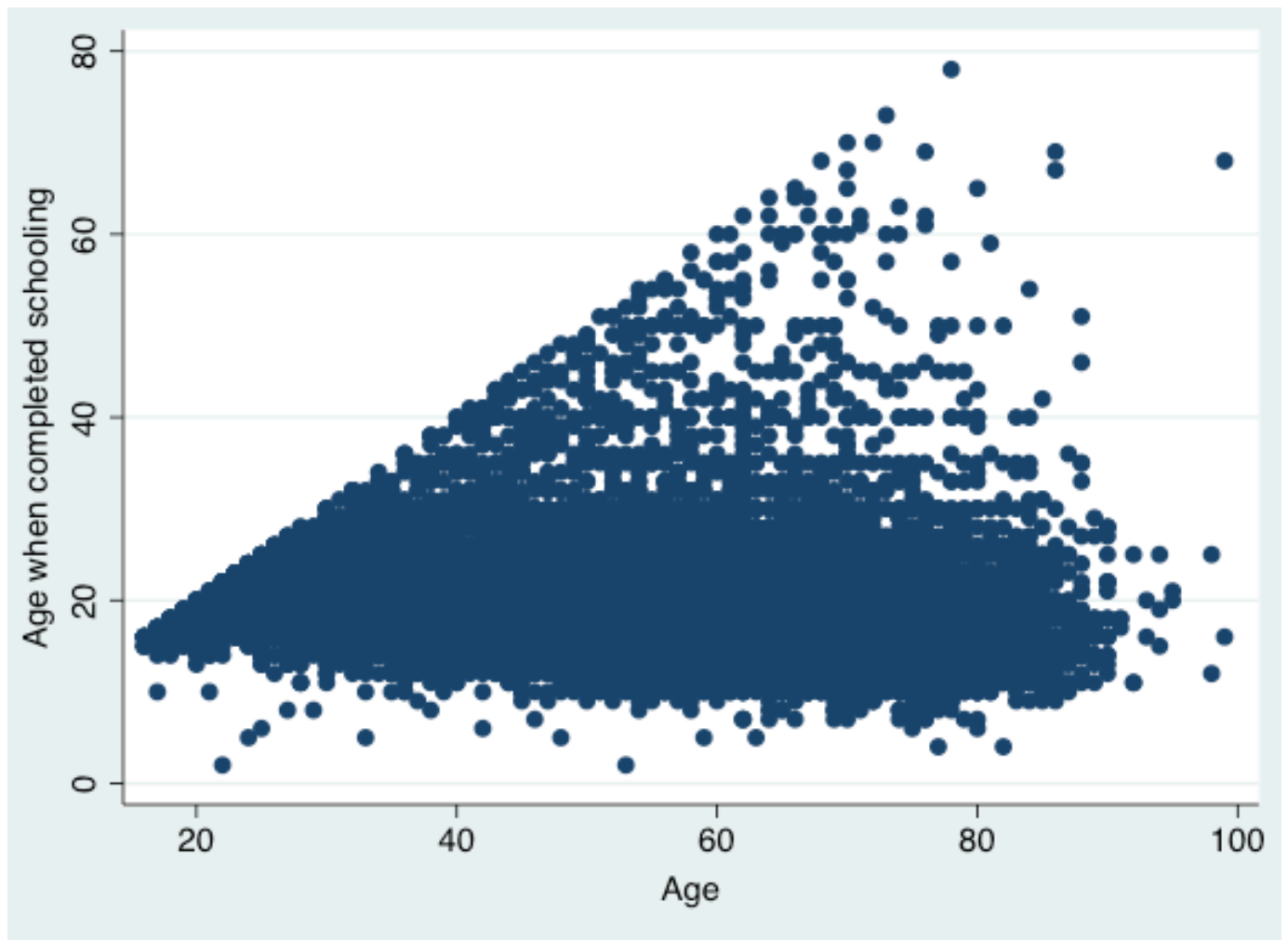

Source: Eurobarometer, 2009

Occupation was not as commonly included in green consumer studies compared with age, gender and education, however without an income variable asked in the Eurobarometer survey, occupation was used to capture some of the socio-economic characteristics of the respondent. Several studies showed (for example, Jain and Kaur, 2008, Chan, 2000) that occupations had an influence on environmental consciousness.

The 2009 Eurobarometer survey divided the occupation variable into twenty one specific occupations (see Appendix 3). In my analysis I created ten dummy variables for occupation segments. Five of them identify 'employed' occupations and the other five cover 'occupations' outside the labour force. The segmentation is reflected in Table 3.6.

\footnotetext{
${ }^{*}$ In all the analyses to follow only people aged 15 and over are included.
} 
Table 3.5: List of education dummy variables used in my analysis

\begin{tabular}{|l|l|l|l|}
\hline $\begin{array}{l}\text { Education level (age when } \\
\text { full-time study completed }\end{array}$ & Observations & $\begin{array}{l}\text { Proportion of all } \\
\text { respondents }\end{array}$ & Category \\
\hline Never & 415 & $1.6 \%$ & Lower education \\
\hline$>15$ & 3634 & $13.7 \%$ & Lower education \\
\hline $16-20$ & 11561 & $43.6 \%$ & Lower education \\
\hline $20+$ & 8590 & $32.4 \%$ & Higher education \\
\hline Still in Education & 1976 & $7.4 \%$ & Lower education \\
\hline Refusal & 466 & $1.3 \%$ & Lower education \\
\hline TOTAL & 26642 & $100 \%$ & \\
\hline
\end{tabular}

Source: Eurobarometer, 2009

Table 3.6 List of occupation dummy variables used in my analysis

\begin{tabular}{|l|l|l|l|}
\hline Occupation & Observations & $\begin{array}{l}\text { Proportion of } \\
\text { all respondents }\end{array}$ & Category \\
\hline Professional & 2044 & $7.7 \%$ & Employed \\
\hline Executive & 781 & $2.9 \%$ & Employed \\
\hline Middle Management & 2595 & $9.8 \%$ & Employed \\
\hline $\begin{array}{l}\text { Employee/Business } \\
\text { owner }\end{array}$ & 5863 & $22.1 \%$ & Employed \\
\hline Manual Worker & 1636 & $6.2 \%$ & Employed \\
\hline Home maker & 1961 & $7.4 \%$ & Not in labour force \\
\hline Student & 1841 & $6.9 \%$ & Not in labour force \\
\hline Retired & 8325 & $31.2 \%$ & Not in labour force \\
\hline Job seeker & 941 & $3.6 \%$ & Not in labour force \\
\hline Refused & 655 & $2.2 \%$ & Not in labour force \\
\hline TOTAL & 26642 & $100 \%$ & \\
\hline
\end{tabular}

Source: Eurobarometer, 2009

Very few studies in recent years have included residence in their analysis of environmental consciousness, however I felt it is important to be included in my testing to see whether environmental consciousness is influenced by population density. My interest is in whether rural residents are more likely to be environmentally conscious that those living in big cities. The observations for residence in the 2009 Eurobarometer survey were spread between respondents living in rural areas $(n=9,373,35 \%$ proportion), other town/urban $(n=11,793,44 \%)$, metropolitan ( $\mathrm{n}=5,269,20 \%$ proportion) and the remainder did know/not available $(\mathrm{n}=207,1 \%)$. I represent these distinctions as dummy variables using town/urban as the base. 


\subsection{Modelling and summary}

In terms of modelling the relationship between responses to environmental questions and characteristics of consumers, I employ regression, logit analysis and multilevel regression (chapter 5). Details are specified as they are needed.

My methodology for examining the influence of age on environmental consciousness is centred around six questions used in the 2009 Eurobarometer survey covering over 26,000 respondents in 28 countries in Europe. By using a serious of dummy variables as controls, and using OLS regression and logit analysis, I will determine how the relationship between age and environmental consciousness holds when various characteristics are taken into account like education level and occupation. Finally I will conduct multilevel regression to ascertain how the relationship between age and environmental consciousness varies across European countries. 


\section{Chapter 4. Analysis}

The relationship between age and environmental consciousness is still a matter of conjecture as the decades of prior research have shown. My own view is that previous authors have underestimated the role of age by not recognising the non-linear effect that age has on environmental consciousness. Before conducting the analysis of the role of age on environmental consciousness, what follows is a look at how European residents responded to some of the questions in the 2009 Eurobarometer survey.

\subsection{Responses to environmental awareness and concern.}

Question 1 was used to determine respondents awareness of the environmental impact of products which people buy. The responses is shown below in Table 4.1.

Table 4.1: Awareness of product impact on the environment, Europe 2009 (EU27 and Croatia combined).

\begin{tabular}{|c|c|c|c|}
\hline $\begin{array}{r}\text { Awareness of environmental impact of } \\
\text { products bought or used }\end{array}$ & Freq. & Percent & Cum. \\
\hline $\begin{array}{r}\text { I know nothing } \\
\text { I know little about this } \\
\text { I know about the most significant impac } \\
\text { I am fully aware }\end{array}$ & $\begin{array}{r}2,216 \\
9,676 \\
10,699 \\
3,587\end{array}$ & $\begin{array}{r}8.47 \\
36.96 \\
40.87 \\
13.70\end{array}$ & $\begin{array}{r}8.47 \\
45.43 \\
86.30 \\
100.00\end{array}$ \\
\hline Total & 26,178 & 100.00 & \\
\hline
\end{tabular}

Source: Eurobarometer, 2009

Table 4.1 indicates that a slightly larger percentage of European consumers are fully aware or mostly aware of the environmental impacts of products bought and used (55\% proportion) than those who know little or nothing about this $(45 \%$ of proportion). The above table can now be effectively broken down into age segments as the following Table 4.2 shows. 
Table 4.2: Awareness of the environmental impact of products bought and used, by age group, Europe 2009 (EU27 and Croatia combined).

\begin{tabular}{|c|c|c|c|c|c|}
\hline $\begin{array}{l}\text { how old } \\
\text { are you? }\end{array}$ & \multicolumn{4}{|c|}{ Awareness of Environmental impact of } & Total \\
\hline $\begin{array}{r}15-24 \\
25-39 \\
40-54 \\
55+\end{array}$ & $\begin{array}{r}11.38 \\
7.09 \\
5.76 \\
10.23\end{array}$ & $\begin{array}{l}44.70 \\
39.86 \\
35.07 \\
35.20\end{array}$ & $\begin{array}{l}35.18 \\
41.66 \\
45.31 \\
38.83\end{array}$ & $\begin{array}{r}8.74 \\
11.39 \\
13.86 \\
15.74\end{array}$ & $\begin{array}{l}100.00 \\
100.00 \\
100.00 \\
100.00\end{array}$ \\
\hline Total & 8.47 & 36.96 & 40.87 & 13.70 & 100.00 \\
\hline
\end{tabular}

Q1. In genera1, how much do you know about the environmental impact of the products you buy and use?

KEY:

$1=\mathrm{I}$ know nothing

$2=I$ know 1ittle about this

$3=I$ know about the most significant impacts

$4=\mathrm{I}$ am fully aware

values are percentages.

Source: Eurobarometer, 2009

In the table above, notice how the proportion of respondents who know about the most significant impacts (3) increases with age, peaks at the 40-54 age segment but then drops off at the highest age group (55+). The reverse is true for those who know nothing (1). These trends represent an early indicator of a likely inverse $U$ shape relationship between age and environmental awareness.

Question 2a examines attitudes towards product impact on the environment. The results are shown below in Table 4.3:

Table 4.3: Concern for product impact on the environment, Europe 2009 (EU27 and Croatia combined).

\begin{tabular}{|c|c|c|c|}
\hline $\begin{array}{r}\text { Importance of the } \\
\text { environmental impact } \\
\text { of products bought } \\
\text { or used }\end{array}$ & Freq. & Percent & Cum. \\
\hline $\begin{array}{r}\text { Not at a11 important } \\
\text { Rather not important } \\
\text { Rather important } \\
\text { Very important }\end{array}$ & $\begin{array}{r}1,021 \\
3,052 \\
12,219 \\
9,602\end{array}$ & $\begin{array}{r}3.94 \\
11.79 \\
47.19 \\
37.08\end{array}$ & $\begin{array}{r}3.94 \\
15.73 \\
62.92 \\
100.00\end{array}$ \\
\hline Total & 25,894 & 100.00 & \\
\hline
\end{tabular}

Source: Eurobarometer, 2009 
As can be seen from Table 4.3, the majority of Europeans' surveyed think that the environmental impact of products bought and used are rather important $(47.19 \%)$ or very important (37.08\%). Combined this tallies to around $84 \%$ who show concern. Only $16 \%$ of the respondents to the 2009 Eurobarometer survey think that the issue is unimportant - either not very important (11.79\%) or not at all important (3.94\%).

In order to gain a clearer picture of the trend over different age groups, Table 4.4 below shows a cross tabulation of age and environmental concern.

Table 4.4: Concern of the environmental impact of products bought and used, by age group, Europe 2009 (EU27 and Croatia combined).

\begin{tabular}{|c|c|c|c|c|c|}
\hline Age group & $\begin{array}{r}\text { Importanc } \\
1\end{array}$ & $\begin{array}{l}\text { the e } \\
\text { cts } b \\
2\end{array}$ & $\begin{array}{c}\text { nmental } \\
\text { or used } \\
3\end{array}$ & $\begin{array}{r}\text { ict of } \\
4\end{array}$ & Total \\
\hline $\begin{array}{r}15-24 \\
25-39 \\
40-54 \\
55+\end{array}$ & $\begin{array}{l}5.32 \\
3.75 \\
3.24 \\
4.19\end{array}$ & $\begin{array}{r}20.79 \\
14.96 \\
10.42 \\
9.26\end{array}$ & $\begin{array}{l}49.47 \\
51.17 \\
50.61 \\
42.58\end{array}$ & $\begin{array}{l}24.43 \\
30.12 \\
35.73 \\
43.97\end{array}$ & $\begin{array}{l}100.00 \\
100.00 \\
100.00 \\
100.00\end{array}$ \\
\hline Total & 3.94 & 11.79 & 47.19 & 37.08 & 100.00 \\
\hline
\end{tabular}

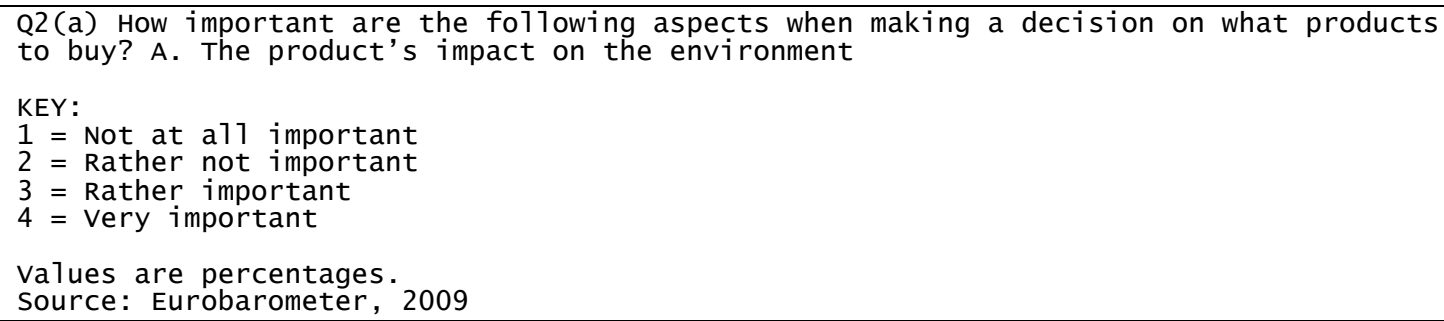

Of particular interest in Table_4.4 is how the proportion of respondents who feel the environmental impact of products is 'very important' (4) increases at least 5\% with each older age segment. Only $24.43 \%$ of those surveyed aged 15-24 felt very concerned which is almost half the proportion of the 55+ age bracket who held the same attitude.

I will now display the responses to the four questions relating to environmental policy. 


\subsection{Responses to the four policy questions.}

Question 3 examines the importance given to ecolabels when purchasing decisions are made and the responses are shown in Table 4.5 below:

Table 4.5: Importance of eco-labels on purchasing decisions, Europe 2009 (EU27 and Croatia combined).

\begin{tabular}{rrrr}
\hline $\begin{array}{r}\text { Importance of eco-1abels in } \\
\text { purchasing decisions }\end{array}$ & Freq. & Percent & Cum. \\
Plays an important part & 12,781 & 49.19 & 49.19 \\
Does not play an important part & 6,279 & 24.17 & 73.36 \\
I never read any labels & 6,922 & 26.64 & 100.00 \\
\hline
\end{tabular}

Source: Eurobarometer, 2009

A total of $49 \%$ of respondents feel ecolabels play an important role in their purchasing decisions where as $51 \%$ don't. This represents quite an evenly proportioned dichotomy. Knowing nothing else I predict for any given European consumer that the chance that they will consider ecolabeling before purchasing a product is around 0.5 .

The following tables list the results for the remaining policy questions. Of particular interest is how popular the support is for mandatory carbon footprint labelling (see Table 4.6).

Table 4.6: Support for mandatory carbon-footprint labels, Europe 2009 (EU27 and Croatia combined).

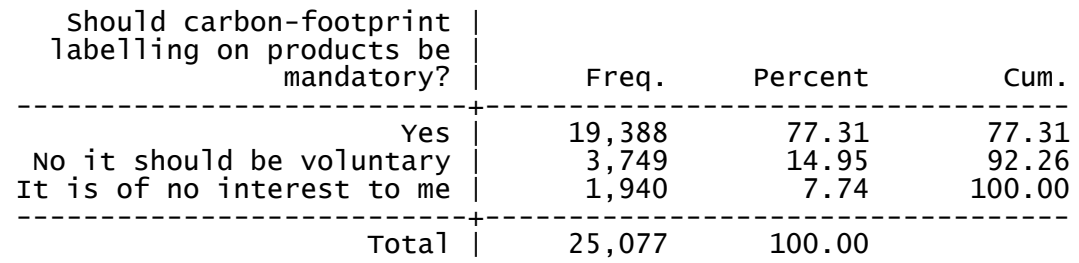

Source: Eurobarometer, 2009 
Table 4.7: Awareness of buying products with the EU flower ecolabel, Europe, 2009 (EU27 and Croatia combined).

\begin{tabular}{|c|c|c|c|}
\hline Awareness of the EU flower ecolabel I & Freq. & Percent & Cum. \\
\hline $\begin{array}{l}\text { I have bought products with this label } \\
\text { I have not bought products with this la } \\
\text { I've never seen it nor heard of it }\end{array}$ & $\begin{array}{r}5,442 \\
5,269 \\
15,175\end{array}$ & $\begin{array}{l}21.02 \\
20.35 \\
58.62\end{array}$ & $\begin{array}{r}21.02 \\
41.38 \\
100.00\end{array}$ \\
\hline Tota1 | & 25,886 & 100.00 & \\
\hline
\end{tabular}

Source: Eurobarometer, 2009

Table 4.8: Support for a voluntary environmental code of conduct for retailers, Europe 2009 (EU27 and Croatia combined).

\begin{tabular}{rrrr} 
Support for EU retailers to develop an & & \\
environmental voluntary code of conduct & Freq. & Percent & Cum. \\
\hline I think it is a good idea & 11,935 & 48.75 & 48.75 \\
It is better to use binding legislation & 10,241 & 41.83 & 100.00 \\
\hline
\end{tabular}

Source: Eurobarometer, 2009

Now that the responses to the dependent variables have been listed, I will examine how age is distributed over the 2009 Eurobarometer survey population and compare this with the age distribution of the EU overall.

\subsection{The Age distribution}

Before analysing the affect of age on environmental awareness, it is important to understand the distribution of age in the 2009 Eurobarometer survey.

Figure 4.1 shows that from ages 15 to 50 the frequency increases and then drops off considerably after age 70. The mode was around 60 years of age. The highest proportion of respondents were aged between 50 and 70. It is unknown why three age segments (ages of around 35, 56 and 77) have lower than expected frequencies considering the general trend. The 2009 Eurobarometer report separated age groups into four groups as shown by Table 4.9. 
Figure 4.1: The distribution of ages across the sample of European respondents, ages 15+ (EU27 and Croatia combined), Europe 2009

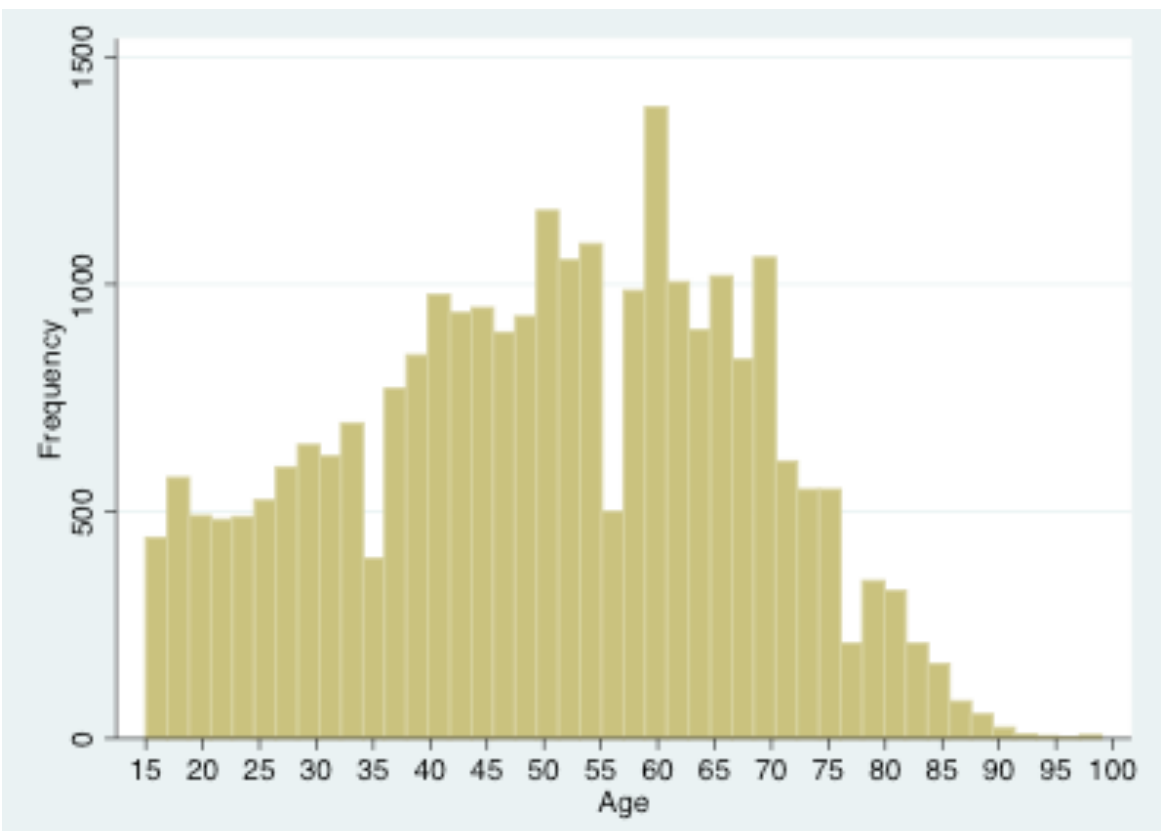

Source: Eurobarometer, 2009

Table 4.9: 2009 Eurobarometer survey responses by age group (EU27 and Croatia combined).

\begin{tabular}{|c|c|c|c|}
\hline $\begin{array}{r}\text { how old are } \\
\text { you? }\end{array}$ & Freq. & Percent & Cum. \\
\hline $\begin{array}{r}15-24 \\
25-39 \\
40-54 \\
55+\end{array}$ & $\begin{array}{r}2,476 \\
5,092 \\
7,464 \\
11,357\end{array}$ & $\begin{array}{r}9.38 \\
19.30 \\
28.28 \\
43.04\end{array}$ & $\begin{array}{r}9.38 \\
28.68 \\
56.96 \\
100.00\end{array}$ \\
\hline Total & 26,389 & 100.00 & \\
\hline
\end{tabular}

Source: Eurobarometer, 2009

Table 4.9 shows that a much higher proportion of respondents were from the older age groups (40-54) and (55+) than the younger (25-39) and (15-24) age groups. It is useful to see whether the age distribution in the 2009 Eurobarometer survey is consistent with the current age distribution in Europe. Figure 4.2 shows the age distribution by gender for the EU27. 
Figure 4.2: Age distribution for EU27, 1990 and 2010 (\% of total population), by gender.

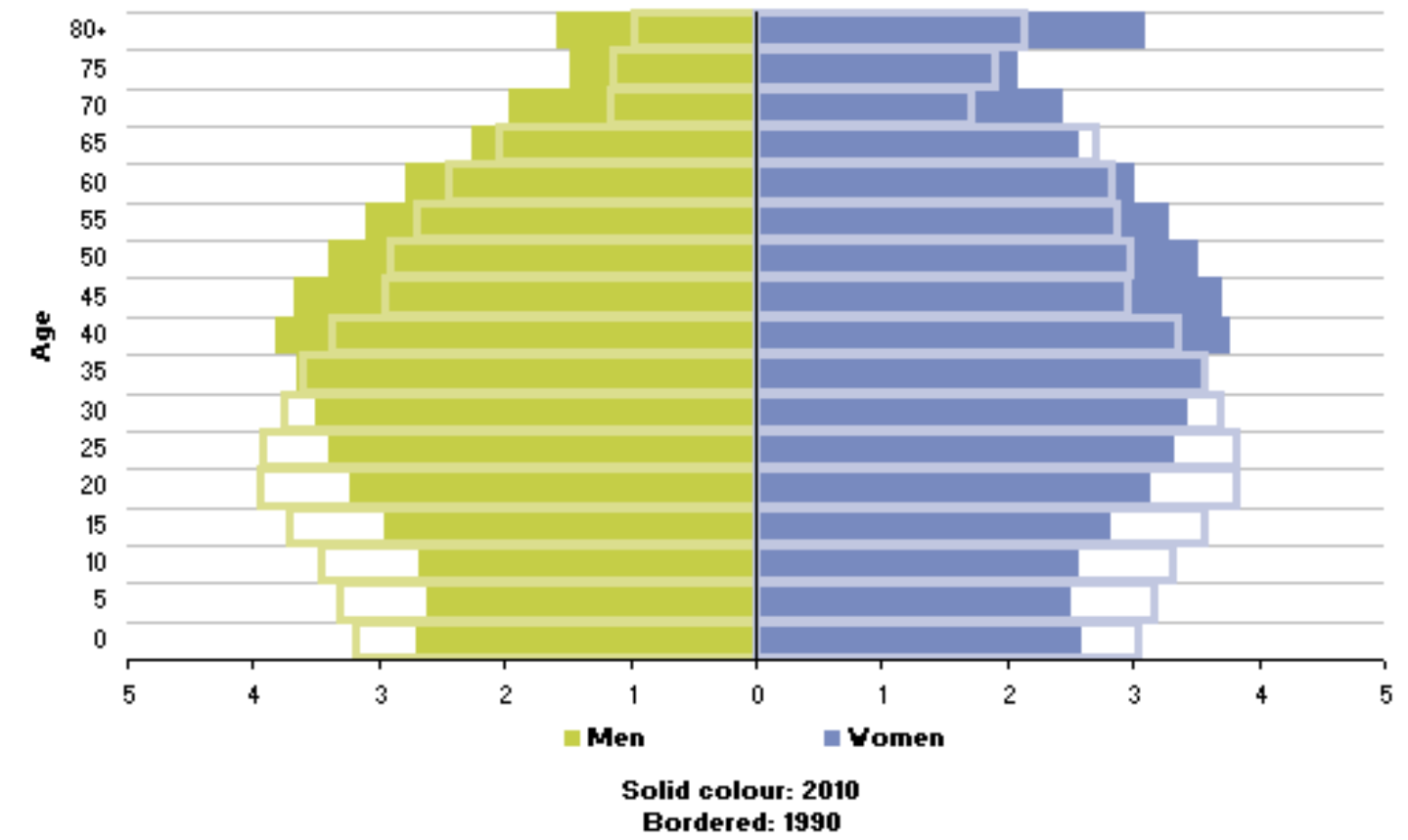

Source: Eurostat, 2011b

Notice in the above graph how the peak frequency of age is the 40-50 age groups for the 2010 data. When comparing Figure 4.1 with Figure 4.2 it is apparent that the 2009 Eurobarometer survey has a higher peak age (around 60) than the EU27 figure which suggests that older persons were overrepresented in the survey relative to the 2010 EU27 population distribution. What follows is an analysis of the relationship between age and environmental consciousness.

\subsection{Age and its effect on environmental awareness}

I begin sections 4.4 and 4.5 by exploring the way in which awareness and concern (respectively) varies with the characteristics of respondents then extend this to the four policy variables in section 4.6. There are a number of methods used to analyse the influence of variables like age or gender on ordered or discrete responses to survey questions. In the case of awareness (Question 1) and concern, (Question 2a) the formally appropriate model is ordered probit or ordered logit. 
However several authors have pointed to the similarity of parameter estimates these models generate to those of ordinary least squares regression (OLS) and since the coefficients are more easily interpreted in the OLS case it has been common to use the apparently less appropriate OLS, (Ferrer-i-Carbonell and Frijters, 2004) which is the method I have used in my analysis.

To illustrate I ask whether having a higher education (completed full-time education at age 20 or above) raises or lowers environmental awareness. The literature says it has a major effect. The following regression indicates the marginal effect each education level has on environmental awareness, relative to those who finished full time study at ages 16-20 (the base).

Table 4.10: Regression table showing the marginal effect each education level has on environmental awareness.

Survey: Linear regression

$\begin{array}{llr}\text { Number of strata } & = & 28 \\ \text { Number of PSUs } & = & 26423\end{array}$

$\begin{array}{llr}\text { Number of obs } & = & 26423 \\ \text { Population size } & = & 26456.781 \\ \text { Design df } & = & 26395 \\ \text { F( 5, 26391) } & = & 52.84 \\ \text { Prob > F } & = & 0.0000 \\ \text { R-squared } & = & 0.0332\end{array}$

\begin{tabular}{|c|c|c|c|c|c|c|}
\hline awarec & Coef. & $\begin{array}{c}\text { Linearized } \\
\text { Std. Err. }\end{array}$ & $\mathrm{t}$ & $P>|t|$ & [95\% Conf. & Interva1] \\
\hline $\begin{array}{l}\text { No_fu11_time_educ } \\
\text { Less_than_fifteen } \\
\text { Age_16_20 }\end{array}$ & $\begin{array}{l}-.2847645 \\
-.2442572 \\
\mathrm{SE})\end{array}$ & $\begin{array}{l}.0989672 \\
.0301506\end{array}$ & $\begin{array}{l}-2.88 \\
-8.10\end{array}$ & $\begin{array}{l}0.004 \\
0.000\end{array}$ & $\begin{array}{l}-.4787455 \\
-.3033539\end{array}$ & $\begin{array}{l}-.0907836 \\
-.1851604\end{array}$ \\
\hline $\begin{array}{r}\text { Age_20plus } \\
\text { Sti11_in_education } \\
\text { Refusa } \\
\text { _cons }\end{array}$ & $\begin{array}{r}.192419 \\
-.1477581 \\
-.1606367 \\
2.608138\end{array}$ & $\begin{array}{l}.0218093 \\
.0369881 \\
.0850879 \\
.0149828\end{array}$ & $\begin{array}{r}8.82 \\
-3.99 \\
-1.89 \\
174.08\end{array}$ & $\begin{array}{l}0.000 \\
0.000 \\
0.059 \\
0.000\end{array}$ & $\begin{array}{r}.1496716 \\
-.2202569 \\
-.3274136 \\
2.578771\end{array}$ & $\begin{array}{r}.2351664 \\
-.0752594 \\
.0061401 \\
2.637505\end{array}$ \\
\hline
\end{tabular}

Source: Eurobarometer, 2009

Table 4.10 in this instance depends on the scale over which awareness is measured. In this case the scale runs from 1 to 4 . If having higher education (Age_20plus) raises the average level of environmental awareness by a quarter of the scale (1) then the estimated coefficient in the above table would be 0.25 . The actual coefficient is slightly lower than this at 0.192 and is statistically significant at the $p<0.05$ level. However, this still shows the strong positive relationship between higher education and increased awareness of the environmental impact of products people buy. With the exception of those who refused to answer, the other education level variables show a negative correlation with awareness relative to those who finished studying at ages $16-20$ and are statistically significant. 
With the method in mind, a similar interpretation applies when regressing awareness on the various age groups, the estimated coefficients indicate the degree to which an increase in each decade of age raises or lowers environmental awareness.

The predicted odds of awareness (Questionnaire Q1) at different age levels is shown in the following regression table. Compared to the base age 55-64, the youngest age groups (15-24) are about half as likely to be aware. Awareness then rises with age, up until middle age and then gradually but more slowly declines.

Table 4.11: Ordinal logit results for the awareness of product impact on the environment by age group.

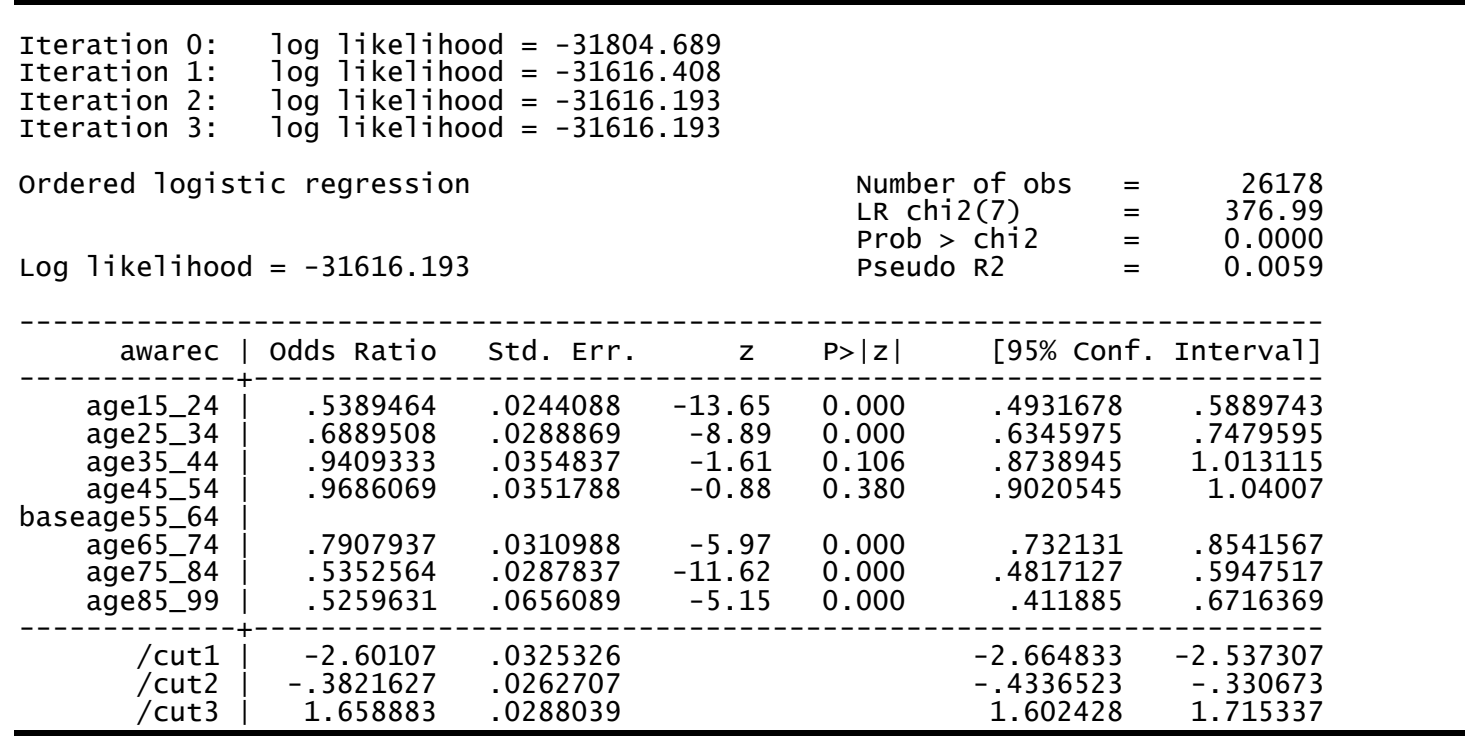

Source: Eurobarometer, 2009

In order to give a more concrete picture of the influence of age on environmental consciousness, I have found it useful to use the estimates obtained from the ordered logit model to plot the predicted probabilities of the different age groups having different levels of awareness. First of all, recall the empirical probabilities of these different categories for the sample. 


$\begin{array}{r}\text { Awareness about the environmental | } \\ \text { impact of products bought or used | }\end{array}$
I know 1jttle about this
I know nothing |

We learn here that almost nine percent of the European respondents say they know nothing. When we calculate the average of the predicted probabilities from the above ordinal logit model they yield approximately the same probabilities as the empirical ones above, as they should. The predicted probabilities vary across respondents of course and the degree to which they vary is apparent from the standard deviations and extremes from the minimum and maximum predictions.

\begin{tabular}{r|rrrrr} 
Variable & Obs & Mean & Std. Dev. & Min & Max \\
\hline Pi1 & 26389 & .0848501 & .0188078 & .0690696 & .1236245 \\
Pi2 & 26389 & .3703564 & .0369482 & .3365358 & .4411007 \\
Pi3 & 26389 & .4080015 & .0313088 & .3442683 & .4344826 \\
Pi4 & 26389 & .136792 & .0244794 & .0910065 & .159912
\end{tabular}

One of the reasons these predicted probabilities vary across individuals is that because they vary by age. It is instructive, in terms of the thesis I'm advancing, to see just how the average of these predicted probabilities vary by age.

Figure 4.3 shows the way in which environmental awareness rises during middle age. The two concave lines refer to the low awareness responses and the two convex lines refer to higher levels of awareness. So the young show a higher probability of 'knowing nothing' (about the impact on the environment of the products they buy). They are also more likely to 'know little'. By contrast the middle aged show lower such probabilities. However both probabilities of knowing nothing and knowing little rise into older age. By contrast, the probability of 'knowing about the most significant impacts' and being 'fully aware' is higher in middle age; those plotted curves are convex over the age domain. 
Figure 4.3: The influence of age on the predicted probability of responses to Question 1 (awareness of product impact on the environment)

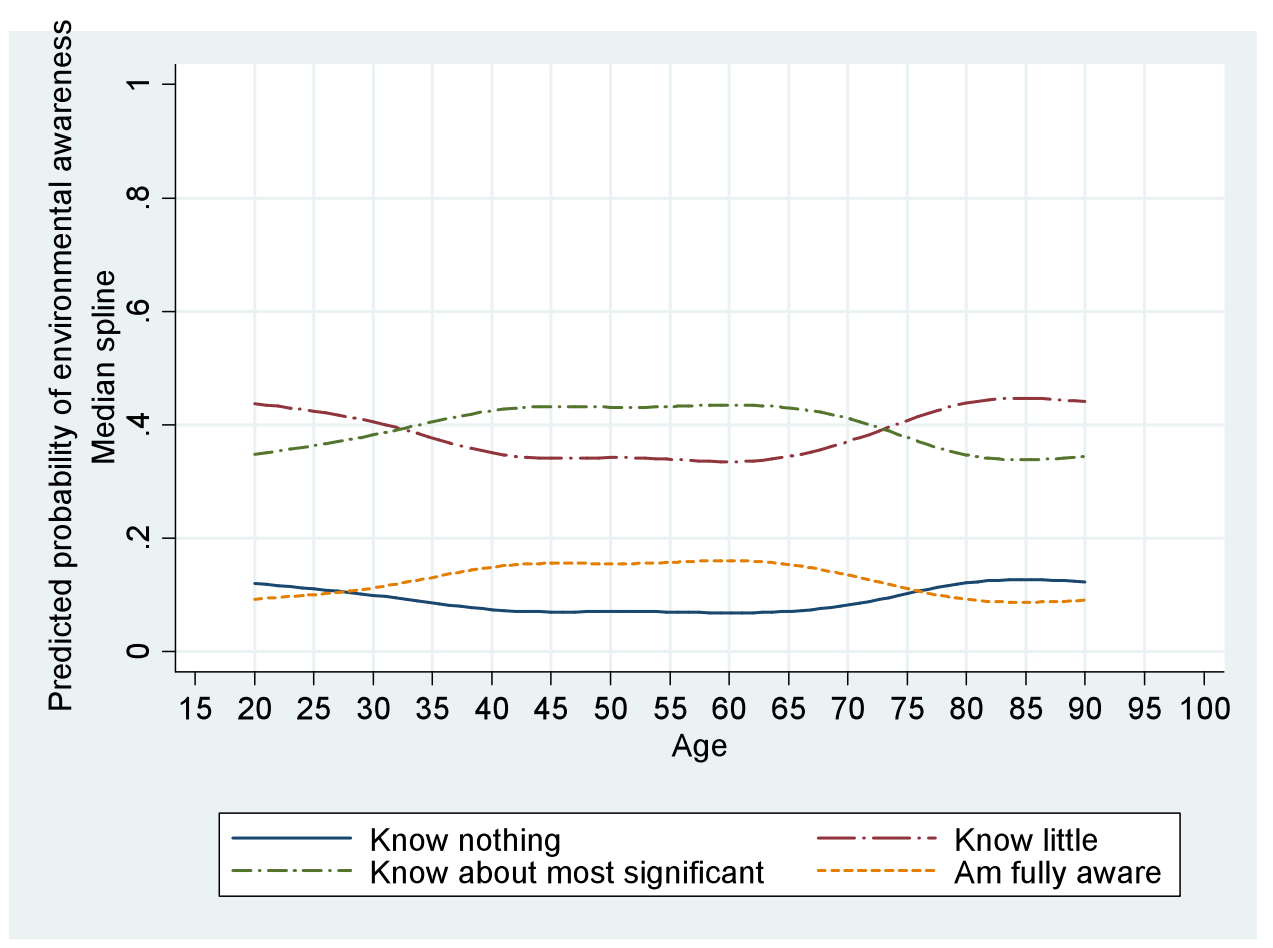

Source: Eurobarometer, 2009

With the above confirmation of inverse $U$ shape between age and awareness I feel confident in replacing the multiple dummy variables above with a more parsimonious, simpler model, one which simply expresses (based this assumption that the ordinal responses can be represented simply as 1,2,3 and 4 and regressed on age). However instead of the multiple dummy variables used above, I simply specify environmental awareness as a quadratic function of age. In order to avoid multicollinearity typical of quadratics I centre the two age terms first, hence Cage and Cage2. The result confirm the evidence from the table above: awareness rises with age, then declines, a relationship which is depicted in the following graph (Figure 4.4). ${ }^{14}$

\footnotetext{
${ }^{14}$ This graph is produced using a method available in Stata called median spline. This basically chops the scatter plot into vertical bands, calculates the bivariate medians for each and then interpolates the median points using cubic splines. (In mathematics a spline is a sufficiently smooth piecewise polynomial function). The median spline is robust to outliers and therefore is a useful way of tracking the way average probabilities change as we do here.
} 
Table 4.12. Regression results for the awareness of the environmental impact of products people buy by age, EU27 and Croatia, 2009.

\begin{tabular}{|c|c|c|c|c|}
\hline $\begin{array}{l}\text { Number of strata } \\
\text { Number of PSUs }\end{array}$ & $\begin{array}{l}= \\
=\end{array}$ & $\begin{array}{r}28 \\
26178\end{array}$ & $\begin{array}{l}\text { Number of obs } \\
\text { Population size } \\
\text { Design df } \\
\text { F( } 2,26149) \\
\text { Prob > F } \\
\text { R-squared }\end{array}$ & $\begin{array}{lr}= & 26178 \\
= & 26292.184 \\
= & 26150 \\
= & 46.25 \\
= & 0.0000 \\
= & 0.0143\end{array}$ \\
\hline awarec & coef. & $\begin{array}{l}\text { Linearized } \\
\text { Std. Err. }\end{array}$ & \multicolumn{2}{|c|}{ [95\% Conf. Interva1] } \\
\hline $\begin{array}{l}\text { Cage } \\
\text { Cage2 }\end{array}$ & $\begin{array}{l}.001425 \\
-.0002673 \\
\text { cons | }\end{array}$ & $\begin{array}{lrr}5 & .0005811 & 2.45 \\
3 & .0000303 & -8.83 \\
2.699608 & .0130452\end{array}$ & $\begin{array}{l}.0002 \\
0.00032\end{array}$ & 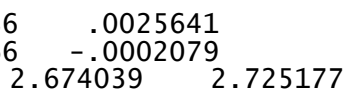 \\
\hline
\end{tabular}

Source: Eurobarometer, 2009

Figure 4.4. The predicted level of awareness of the environmental impact of products people buy by age, EU27 and Croatia, 2009.

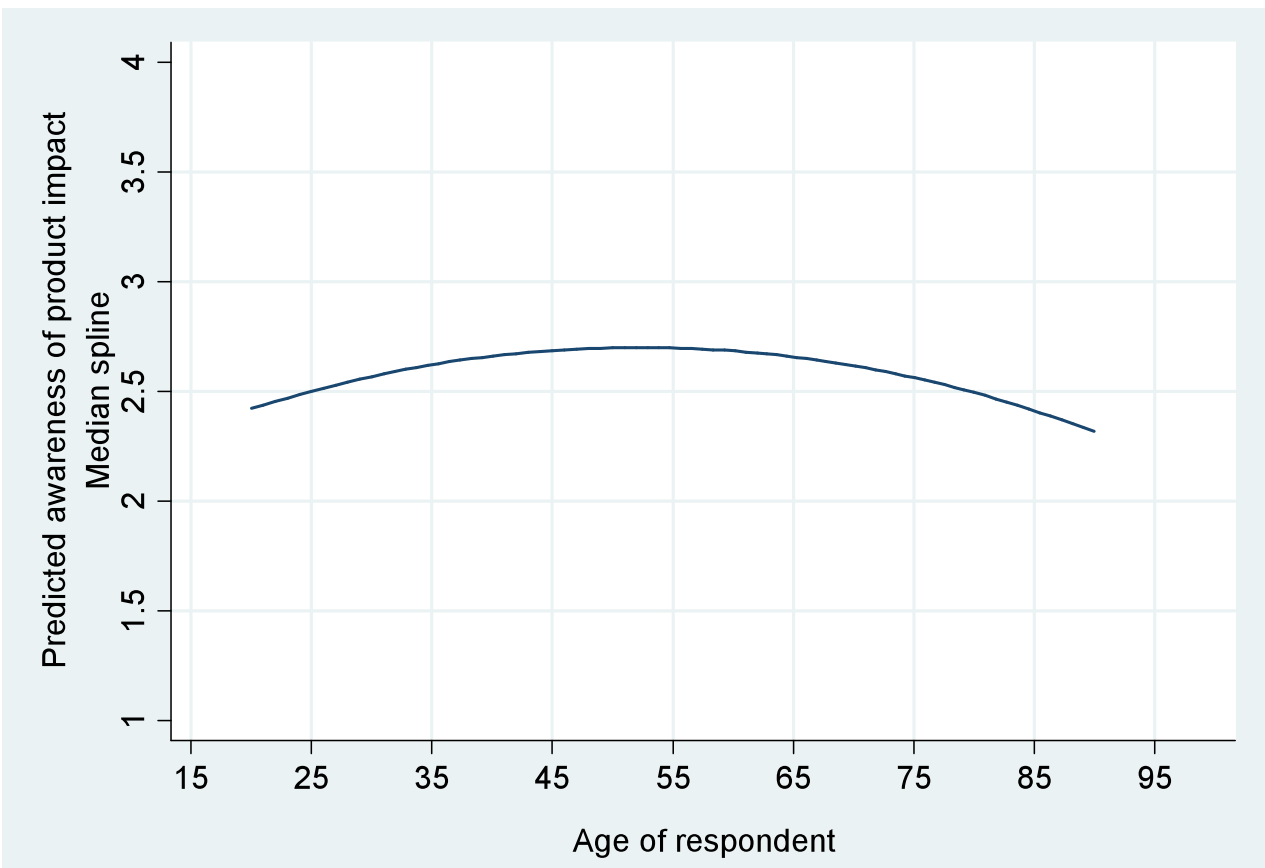

Source: Eurobarometer, 2009

Figure 4.4 demonstrates the predicted inverse $U$ shape relationship between age and environmental consciousness, in this case, awareness of the environmental impact of products people buy. The median spline is a useful graphical summary device. However it does not tell us whether there is in fact a statistically significant difference between the level of awareness of youth and middle age or between the old and the 
middle aged. The question of whether the level of environmental awareness changes significantly with age is best answered by regressing awareness on dummy variables depicting ten year age groups as follows:

Table 4.13: Regression results for the awareness of product impact on the environment by age group.

\begin{tabular}{|c|c|c|c|c|c|c|}
\hline $\begin{array}{l}\text { Number of strata } \\
\text { Number of PSUs }\end{array}$ & $\begin{array}{l}= \\
=\end{array}$ & $\begin{array}{r}28 \\
26178\end{array}$ & & $\begin{array}{l}\text { Number } \\
\text { Popula } \\
\text { Desigr } \\
\text { FC } \\
\text { Prob } \\
\text { R-squa }\end{array}$ & $\begin{array}{l}f \text { obs } \\
\text { on size } \\
\text { f } \\
\text { 26144) }\end{array}$ & $\begin{array}{lr}= & 26178 \\
= & 26292.184 \\
= & 26150 \\
= & 15.76 \\
= & 0.0000 \\
= & 0.0153\end{array}$ \\
\hline awarec & Coef. & $\begin{array}{l}\text { Linearized } \\
\text { Std. Err. }\end{array}$ & $\mathrm{t}$ & $P>|t|$ & {$[95 \%$ Conf } & . Interva1] \\
\hline $\begin{array}{l}\text { age } 15 \_24 \\
\text { age25_34 } \\
\text { age35_44 } \\
\text { age45_54 }\end{array}$ & $\begin{array}{r}-.323192 \\
-.1795364 \\
-.1032048 \\
-.0372477\end{array}$ & $\begin{array}{l}.0375523 \\
.0339846 \\
.0319929 \\
.0299548\end{array}$ & $\begin{array}{l}-8.61 \\
-5.28 \\
-3.23 \\
-1.24\end{array}$ & $\begin{array}{l}0.000 \\
0.000 \\
0.001 \\
0.214\end{array}$ & $\begin{array}{l}-.3967965 \\
-.2461481 \\
-.1659126 \\
-.0959608\end{array}$ & $\begin{array}{r}-.2495875 \\
-.1129247 \\
-.040497 \\
.0214654\end{array}$ \\
\hline $\begin{array}{r}\text { age65_74 } \\
\text { age75_84 } \\
\text { age85_99 }\end{array}$ & $\begin{array}{r}-.1307231 \\
-.2714822 \\
-.207074\end{array}$ & $\begin{array}{l}.0361168 \\
.0467122 \\
.1106691\end{array}$ & $\begin{array}{l}-3.62 \\
-5.81 \\
-1.87\end{array}$ & $\begin{array}{l}0.000 \\
0.000 \\
0.061\end{array}$ & $\begin{array}{l}-.2015141 \\
-.3630408 \\
-.4239915\end{array}$ & $\begin{array}{r}-.0599321 \\
-.1799236 \\
.0098434\end{array}$ \\
\hline _cons | & 2.737871 & .0217906 & 125.64 & 0.000 & 2.69516 & 2.780582 \\
\hline
\end{tabular}

Source: Eurobarometer, 2009

The base for the above age dummies is again, the 55-64 age group. These results confirm that there is a statistically significantly lower relative level of awareness by those aged 15-24 years, and to lesser extent, the 25-34 and 35-44 age groups. This gap diminishes as respondents get older as Tables 4.11 and 4.13 show. As age increases above middle aged level, my results show that awareness falls although with somewhat more variability. ${ }^{15}$

In summary, a combination of probability plots and regression on the age dummy variables, reveals the presence of a $U$ shaped relationship between environmental awareness and age. Having established that there is a convex relationship between these two variables, I now turn to whether this same relationship also holds for the concern associated with the environmental impact of the products European residents buy and use.

\footnotetext{
${ }^{15}$ This may be in part due to the low number of observations at the higher age groups $(80+)$. (Recall the age distribution graph (Figure 4.1) on page 50
} 


\subsection{Age and its effect on environmental concern}

Turning now to the degree to which respondents feel that products impact on the environment is important in their purchase decisions, it is apparent from Table 4.14 that the large majority of respondents give this issue considerable importance.

Table 4.14: Concern for product impact on the environment, Europe 2009 (EU27 and Croatia combined).

\begin{tabular}{|c|c|c|c|}
\hline $\begin{array}{r}\text { Importance of the } \\
\text { environmental impact } \\
\text { of products bought } \\
\text { or used }\end{array}$ & Freq. & Percent & Cum. \\
\hline $\begin{array}{r}\text { Not at a11 important } \\
\text { Rather not important } \\
\text { Rather important } \\
\text { Very important }\end{array}$ & $\begin{array}{r}1,021 \\
3,052 \\
12,219 \\
9,602\end{array}$ & $\begin{array}{r}3.94 \\
11.79 \\
47.19 \\
37.08\end{array}$ & $\begin{array}{r}3.94 \\
15.73 \\
62.92 \\
100.00\end{array}$ \\
\hline Tota 7 & 25,894 & 100.00 & \\
\hline
\end{tabular}

Source: Eurobarometer, 2009

The majority of Europeans' surveyed think that the environmental impact of products people buy are rather important $(47.19 \%)$ or very important $(37.08 \%)$. Combined this tallies to around $84 \%$ who show concern. Only $16 \%$ of the respondents to the 2009 Eurobarometer survey think that the issue is unimportant - either not very important $(11.79 \%)$ or not at all important (3.94\%).

The regression of centred measures of age and age ${ }^{2}$ on concern is given in Table 4.15. I begin with the quadratic regression results and correlated graph for both awareness and concern on the next page to get a comparison. The predicted values of the regression results from Table 4.15 are graphed in Figure 4.5 below (dotted line), and I have included the plots for both awareness and concern in order to draw a comparison. The $y$ scale is the average of the responses on the 1-4 scale in question 1 and 2. 
Table 4.15: Regression results for the level of concern of environmental impact of products people buy by age, EU27 and Croatia, 2009.

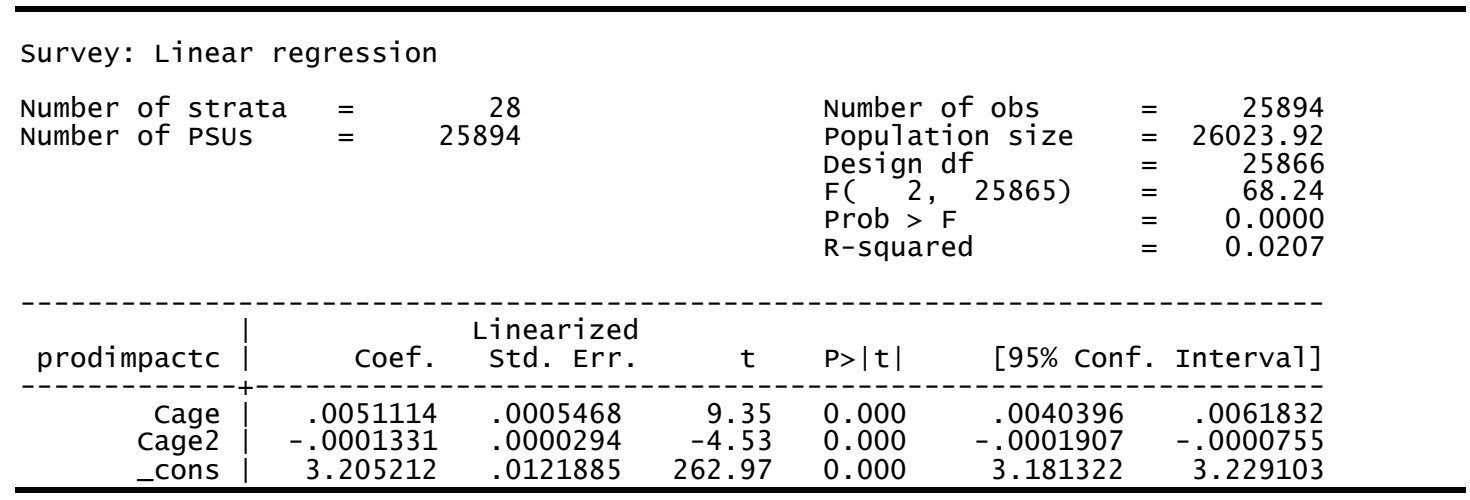

Source: Eurobarometer, 2009

Figure 4.5: The predicted level of awareness and concern for the environmental impact of products people buy by age, EU27 and Croatia, 2009.

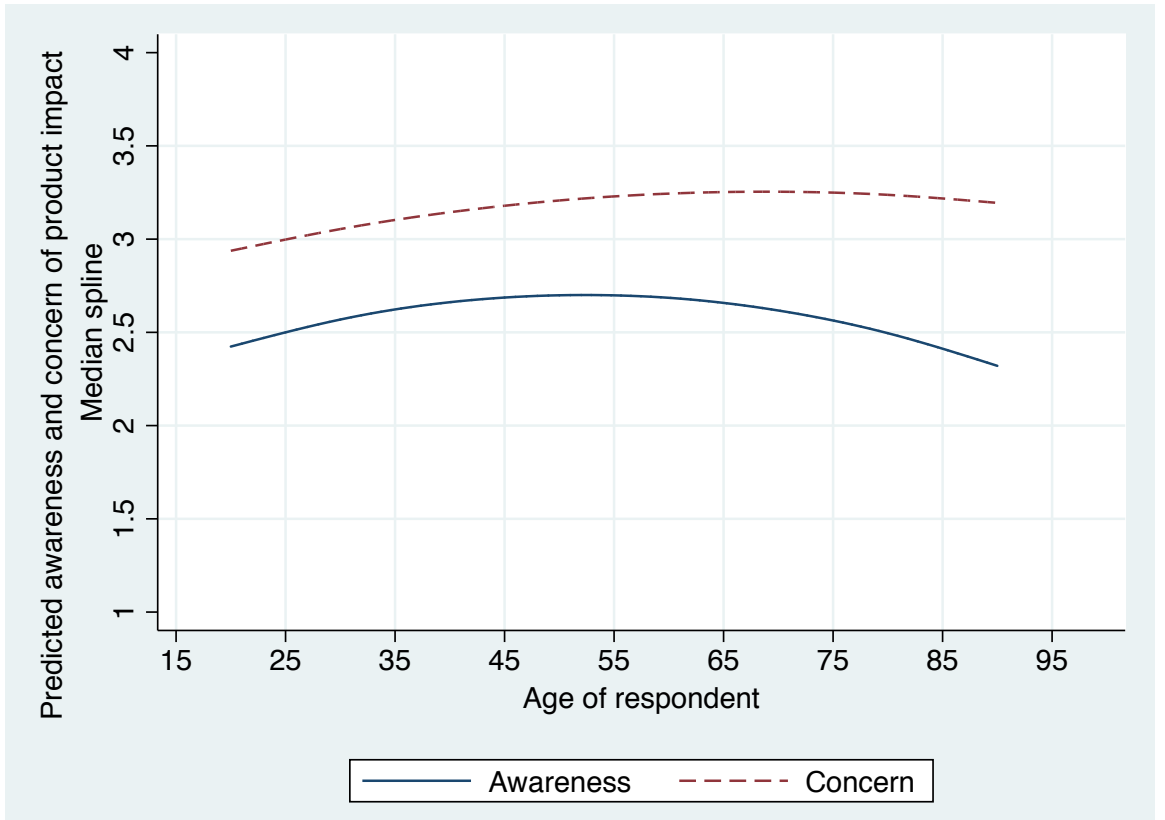

Source: Eurobarometer, 2009

In both Table 4.15 and Figure 4.5 there are significant non-linear age effects, in favour of middle aged consumers in both cases, a result consistent with the research reported by Finisterra do Paço and Raposo, (2010); Abeliotis et al. (2010); Bantye et al. (2010) and Franzen and Meyer (2009). The regression confirms the much lower level of concern associated with younger consumers, and follows a similar trend of 
awareness in that increased age raises the concern of impact on the environment of products.

Consistent with the regression results in Table 4.13, I use the same base age segment of 55-64 (see Table 4.16). In this instance the peak of environmental consciousness occurs later, among those aged 65-74, after which concern by those aged $75+$ takes a negative sign, however note that it is not statistically significant. Whilst the results for concern can show that the importance attached to product impact rises noticeably with age, unlike the case of awareness I cannot demonstrate any statistically significant diminution in concern into older age a result which is consistent with the flatness of the curve from the 60s age group onwards in Figure 4.5.

\section{Table 4.16: Regression results for the awareness of product impact on the environment by age group.}

\begin{tabular}{|c|c|c|c|c|c|c|}
\hline $\begin{array}{l}\text { Number of strata } \\
\text { Number of PSUs }\end{array}$ & $\begin{array}{l}= \\
=\end{array}$ & $\begin{array}{r}28 \\
25894\end{array}$ & & $\begin{array}{l}\text { Number } \\
\text { Popu1a } \\
\text { Design } \\
\text { FC } 7 \\
\text { Prob > } \\
\text { R-squa }\end{array}$ & $\begin{array}{l}f \text { obs } \\
\text { on size } \\
f \\
25860 \text { ) } \\
d\end{array}$ & $=\begin{array}{r}25894 \\
26023.92 \\
25866 \\
21.00 \\
0.0000 \\
0.0213\end{array}$ \\
\hline prodimpactc & Coef. & $\begin{array}{c}\text { Linearized } \\
\text { Std. Err. }\end{array}$ & $\mathrm{t}$ & $P>|t|$ & [95\% Conf. & Interva1] \\
\hline $\begin{array}{r}\text { age } 15=24 \\
\text { age } 25 \_34 \\
\text { age } 35 \_44 \\
\text { age } 45 \_54 \\
\text { baseage } 55-64\end{array}$ & $\begin{array}{l}-.2832805 \\
-.2212956 \\
-.0959932 \\
-.047049\end{array}$ & $\begin{array}{l}.033733 \\
.0326061 \\
.0289625 \\
.0278686\end{array}$ & $\begin{array}{l}-8.40 \\
-6.79 \\
-3.31 \\
-1.69\end{array}$ & $\begin{array}{l}0.000 \\
0.000 \\
0.001 \\
0.091\end{array}$ & $\begin{array}{r}-.349399 \\
-.2852054 \\
-.1527612 \\
-.1016731\end{array}$ & $\begin{array}{r}-.217162 \\
-.1573857 \\
-.0392252 \\
.0075751\end{array}$ \\
\hline $\begin{array}{l}\text { age65_74 } \\
\text { age75_84 } \\
\text { age85_99 }\end{array}$ & $\begin{array}{r}.0650705 \\
-.0399585 \\
-.010208\end{array}$ & $\begin{array}{l}.0302365 \\
.0478163 \\
.0953463\end{array}$ & $\begin{array}{r}2.15 \\
-0.84 \\
-0.11\end{array}$ & $\begin{array}{l}0.031 \\
0.403 \\
0.915\end{array}$ & $\begin{array}{r}.0058052 \\
-.1336811 \\
-.1970919\end{array}$ & $\begin{array}{r}.1243358 \\
.0537641 \\
.176676\end{array}$ \\
\hline _cons | & 3.237212 & 0199515 & 162.25 & 0.000 & 3.198106 & 3.276319 \\
\hline
\end{tabular}

Source: Eurobarometer, 2009

In summary, although awareness and concern are positively correlated, their relationship to age differs slightly. Whereas awareness falls as people reach their older years, they tend to maintain their concern for the environmental impact that products have. Now I will turn to European residents support of policy initiatives designed to protect the environment as addressed by four questions asked in the questionnaire. 


\subsection{Age and environmental policy options}

In light of the above results it is interesting to see how age influences the support of the various policy instruments included in the 2009 Eurobarometer survey. In the following four examples I estimate a logit model and plot the probability of the response to those policy instruments against age.

Beginning with the importance of ecolabels on products (question 3), the most appropriate specification here is logistic regression analysis, with the results of the policy initiative questions dichotomised between high (coded 1) and low environmental consciousness ( coded 0$)$.

Table 4.17: Binary variables for the importance of eco-labels on purchasing decisions, Europe 2009 (EU27 and Croatia combined).

\begin{tabular}{r|rrr}
\hline & & \\
ecolabe1p & Freq. & Percent & Cum. \\
-0 & 13,318 & 50.77 & 50.77 \\
1 & 12,912 & 49.23 & 100.00 \\
$-10 t a 1$ & 26,230 & 100.00 & \\
\hline
\end{tabular}

Q3. Some products have an ecolabel which certifies that they are environmenta11y-

friendly. How important are ecolabels in your purchasing decisions?

KEY:

$0=$ Not important/not interested

1 = Important

Source: Eurobarometer, 2009

Using the above binary variables, I conduct the logistic regression for the ecolabels variable and the outcome is tabulated below in Table 4.18 and graphed in Figure 4.6. 
Table 4.18: Regression results for the importance of eco-labels on purchasing decisions

Survey: Logistic regression

$\begin{array}{llr}\text { Number of strata } & = & 28 \\ \text { Number of PSUs } & = & 25982\end{array}$

Number of obs $=25982$

Population size $=26099.237$

$=25954$

$\begin{array}{lll}\mathrm{F}(\mathrm{2}, 25953) & =61.50 \\ \text { Prob }>\mathrm{F} & 0.0000\end{array}$

\begin{tabular}{|c|c|c|c|c|c|c|}
\hline ecolabe 1b & coef. & $\begin{array}{c}\text { Linearized } \\
\text { std. Err. }\end{array}$ & $\mathrm{t}$ & $P>|t|$ & [95\% Conf. & Interva1] \\
\hline $\begin{array}{r}\text { Cage } \\
\text { Cage2 } \\
\text { _cons }\end{array}$ & $\begin{array}{r}.0104959 \\
-.0005341 \\
.1355147\end{array}$ & $\begin{array}{l}.0013495 \\
.0000715 \\
.0314386\end{array}$ & $\begin{array}{r}7.78 \\
-7.48 \\
4.31\end{array}$ & $\begin{array}{l}0.000 \\
0.000 \\
0.000\end{array}$ & $\begin{array}{r}.0078509 \\
-.0006742 \\
.0738933\end{array}$ & $\begin{array}{r}.0131409 \\
-.0003941 \\
.1971361\end{array}$ \\
\hline
\end{tabular}

Source: Eurobarometer, 2009

Figure 4.6. The predicted probability of importance of ecolabels in purchasing decisions, EU27 and Croatia, 2009.

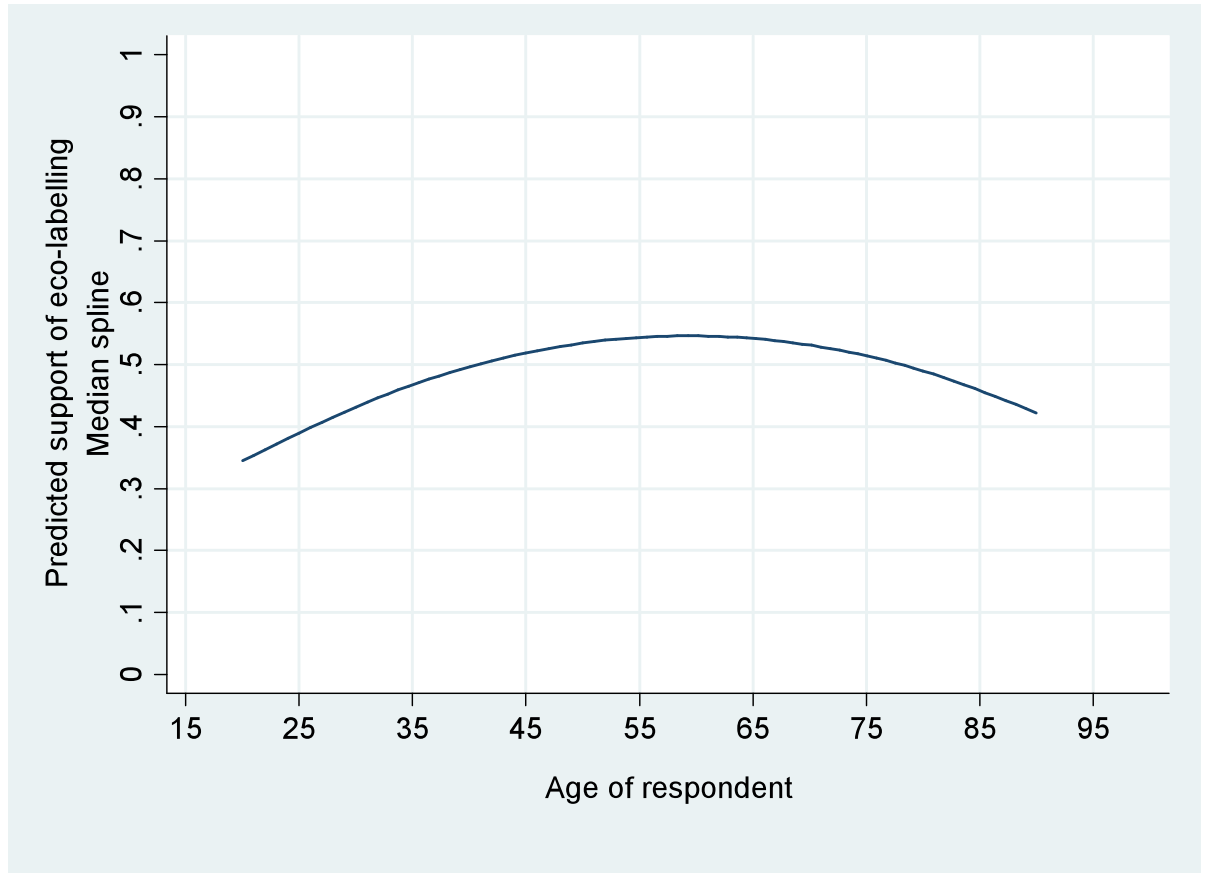

Source: Eurobarometer, 2009

The above graph shows how support for ecolabelling is also quadratic in age. Once again it is the middle aged who are most in support of ecolabelling (although they are only slightly more than 0.5 in favour) and the youth least likely with an estimated median probability of around 0.35 . 
I conduct the same logistic regressions and predictions for the other three policy initiative variables - support for carbon footprint labelling (question five), awareness of the EU flower label (question nine) and support for binding environmental codes of conduct (question thirteen). The results are graphed in conjunction with the plots for ecolabelling in figure_below in order to draw a comparison.

Figure 4.7. The predicted probability of support for various environmental policy initiatives, EU27 and Croatia, 2009.

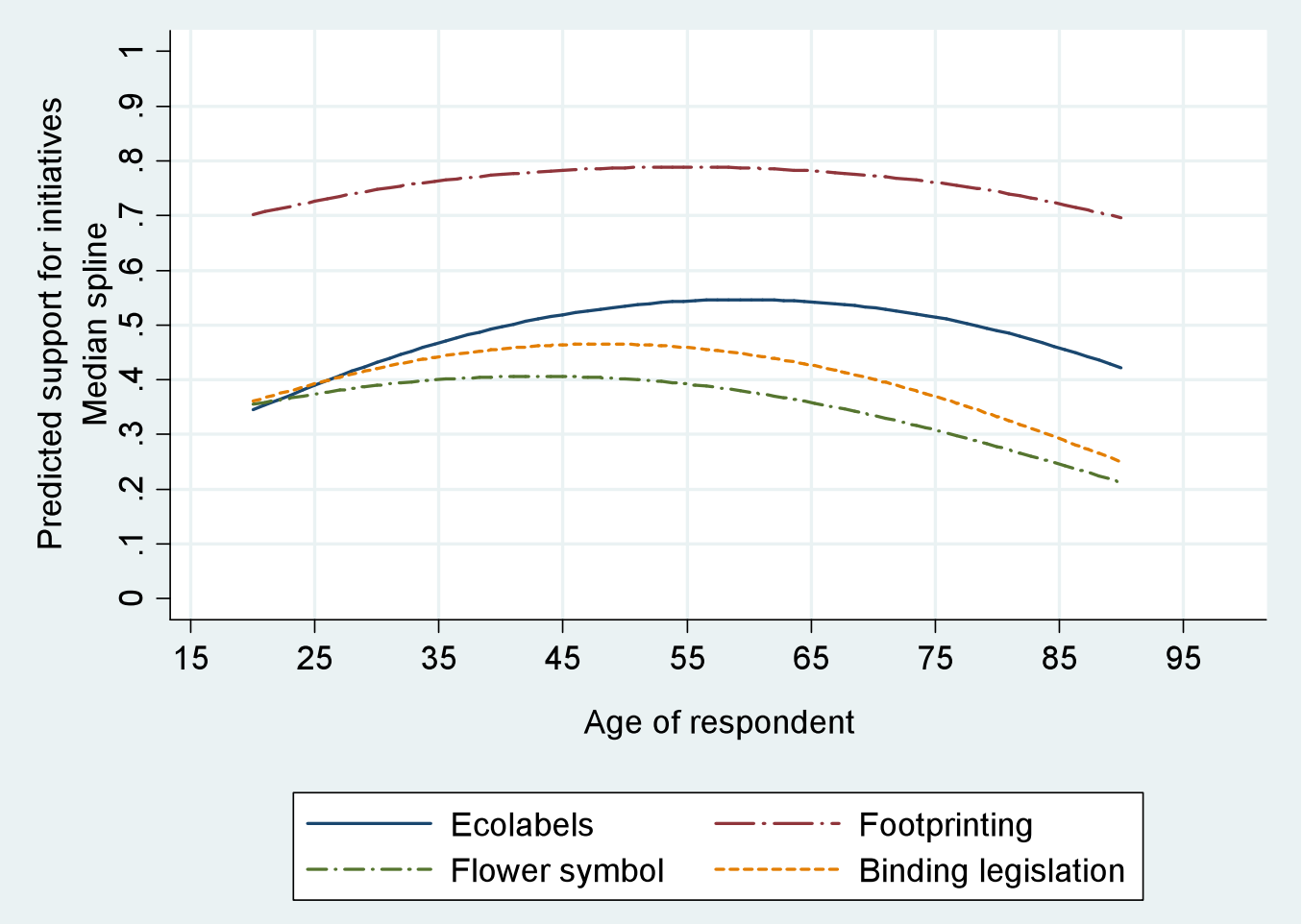

Source: Eurobarometer, 2009

There are several points to highlight from Figure 4.7. The first is that all four plots show an inverted $U$ shape trend in the relationship between environmental consciousness and age. A second point to note is a much higher and consistent consensus across the ages when it comes to supporting mandatory carbon footprint labels (footprinting) on products compared to the other policy initiatives. While the other three initiatives achieve an average consensus among the young, this tends to diverge with age, especially between the use of ecolabels and use of the flower symbol (which behaves more like support for binding legislation). Thirdly, the peak 
in environmental consciousness relating to the EU flower symbol and binding environmental codes of conduct comes at an earlier age (around the 40-50 age) than support for carbon footprints and especially importance of ecolabels where the peak is closer to the 55-65 age. I am unsure as to why this might be.

Overall, support is highest for carbon footprinting, then ecolabelling, then binding legislation then use of the flower symbol. It is not immediately clear why this hierarchy exists. I now will examine the influence of the control variables on the relationship between age and environmental consciousness to see how the consistent inverse U shape trend holds.

\subsection{The influence of the control variables}

It is a possibility that the relationship between age and environmental consciousness thus far could in fact (just) be the result of events and circumstances common to particular life stages. It is important to try and separate them out. For example if the negative effect of young age on environmental awareness was due partly to higher rates of unemployment among European youth then that involves quite a different policy issue than if it was a feature simply of being young. Similarly, how much of the student effect is actually being young as opposed to gaining higher learning? Sometimes the two can compete with each other.

My analysis will now focus on whether the inverse $U$ shape relationship between age and environmental consciousness prevails even with controls. To do this, I will conduct analyses using the variables - gender, education level, occupation and residence to see how they influence the relationship between 1) age and awareness of environmental impact and 2) age and concern for environmental impact.

The aim in the following analysis is to see what happens to the effect of age when I include the various occupations (which can also refer to life-cycle effects). This is done using four models. Model 1 tests for the relationship between age and awareness. Model 2 includes age ${ }^{2}$ in order to gauge non-linearity. Model 3 includes all the control variables with the exception of 'unemployed' occupations. Model 4 
includes all the above as well as both 'employed' occupations and 'non-employed' occupations. The results of all four models are displayed in table 4.19.

\section{Table 4.19. Results of multiple regression analyses covering awareness of environmental impact of products (with controls).}

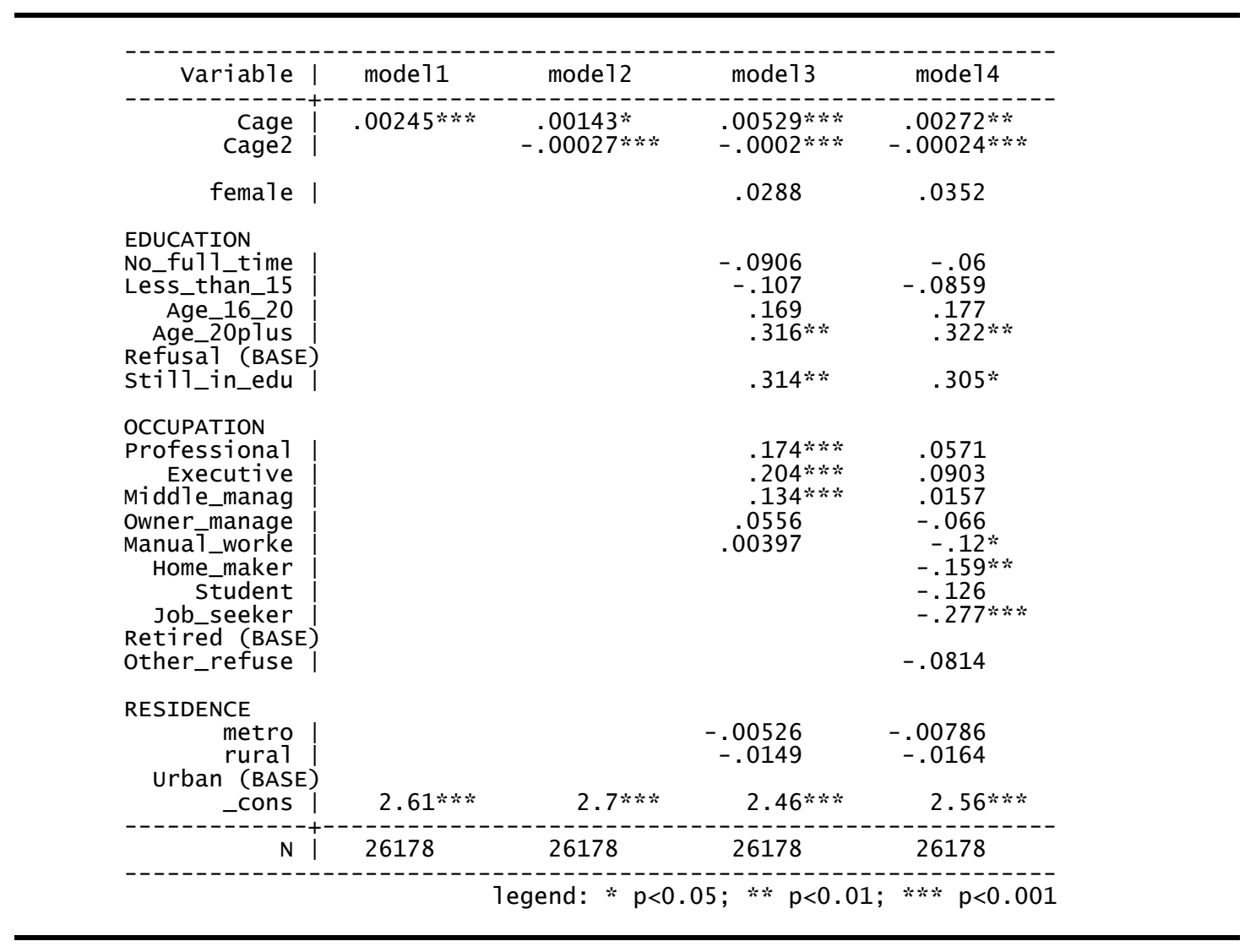

Source: Eurobarometer, 2009

The results from Table 4.19 are instructive. Model 1 shows that running awareness as a linear function of age does generate a significant relationship. Unfortunately many previous studies stopped at this point and did not go further with the age variable testing for non-linearity. In fact, when model 2 is run I find that the non-linear model fits better (over doubling the $\mathrm{R}^{2}$ ). This non-linear (inverse $\mathrm{U}$ shape) model becomes even more significant when we include gender, education levels, the occupations of the employed and residence (which is not significant). The variables that are most significantly correlated (positively) with awareness in model 3 are higher education (finished studying at age 20 and above) and (the related group of) professionals and executives, all of which increase environmental awareness. The base here is the nonemployed. 
Another point to note from Table 4.19 is that the correlation coefficients change a lot when the variables of the non-employed are included: home makers, students, job seekers and refusal (retired is the base). Compared to the retired, home makers and job seekers show much lower levels of awareness. The identified occupations are now compared to the retired rather than all those not in the labour force and the employed in general are not now as different from the retired as they were from the nonemployed in terms of their level of environmental awareness.

\section{Figure 4.8. Predicted level of awareness of environmental impact of products with and without controls}

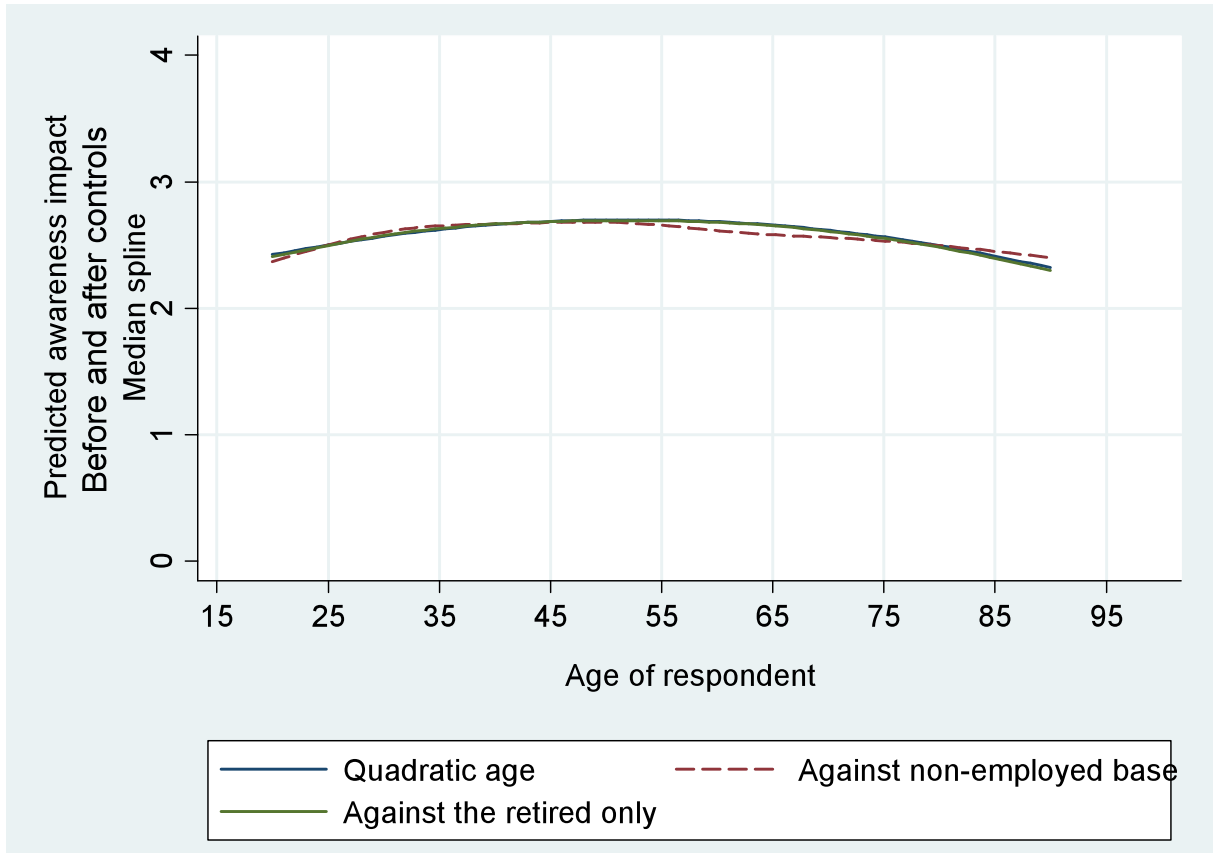

Source: Eurobarometer, 2009

An important observation from model 4 is that once the retired occupation group becomes the base, when I take into account students and job seekers (both of whom are typically young, as well as home makers who are also usually in their 20s and $30 \mathrm{~s}$ ), then the effect of simply being young on environmental awareness diminishes. Therefore, it is not necessarily being young per se that appears to lower awareness, but the fact that many of the young at least exhibit certain characteristics - they are often either students, unemployed or raising young children. 
As is clearly shown in Figure 4.8, the difference in predicted awareness is negligible with the inclusion of control variables. Taking this analysis a further step, I conduct a more specific test of the effect of being young on awareness by confining the sample to the employed only. ${ }^{16}$ Note this drops the sample size by less than half. I run the same models again but this time just for the employed. The results in the following table confirm the growth in awareness with age, and the fact that the coefficient on Cage changes only slightly when controls for education and occupation are added. In other words awareness rises with age even when I account for the fact that both education and type of employment varies by age. What is different from the previous table which was for the whole population is the impact of advancing years. The coefficient on Cage 2 remains negative but is not significant simply because there are few such older respondents present when I include only the employed.

\section{Table 4.20. Results of multiple regression analysis covering awareness of environmental impact of products (with controls).}

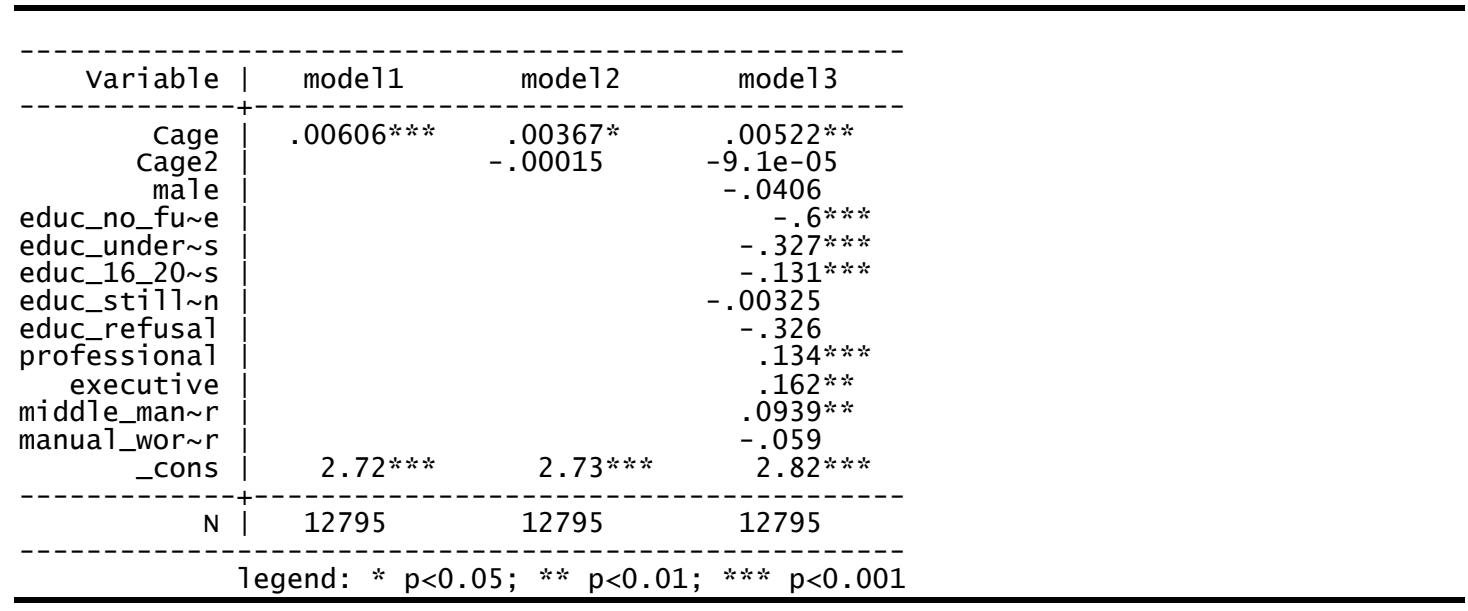

Source: Eurobarometer, 2009

In order to confirm the above result I plot the predicted values of awareness on the basis of the quadratic age model (model 2 above) and then with the controls in place. As anticipated, the two lines are very close, rising in age but not decreasing in age among the older employed.

\footnotetext{
${ }^{16}$ No particular occupation appears to have a disproportionate proportion of young or old people for example. The 'employed' occupations are distributed across the age groups in a very similar manner.
} 
Figure 4.9: Predicted level of awareness of environmental impact of products across age with and without controlling for education and occupations. Europe 2009

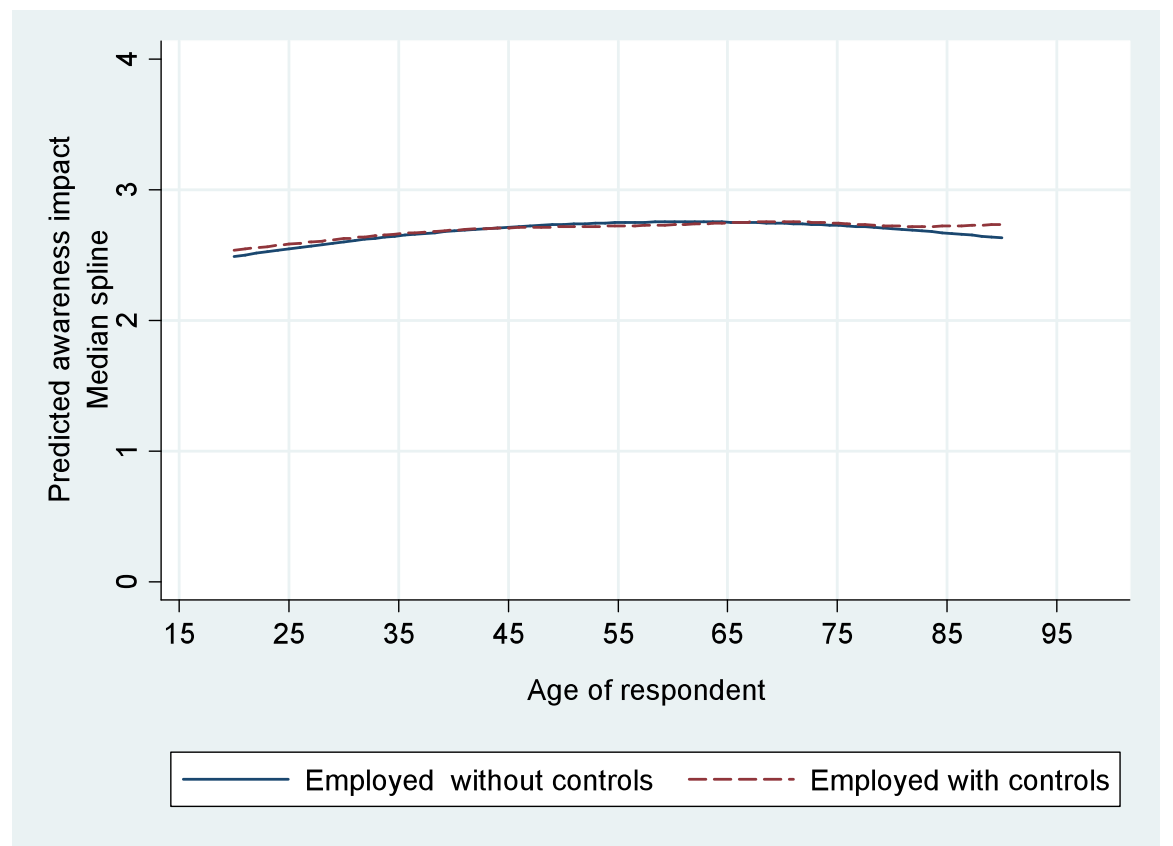

Source: Eurobarometer, 2009

Now I turn to concern of environmental impact and assess the stability of its relationship with age with and without the same controls. The results of the regression analysis for concern are shown in Table 4.21.

The results of the regression analyses for concern of environmental impact of products shows that firstly, the inverse U shape holds with the inclusion of controls. Secondly, females show a higher level of concern than males, thirdly living in either a metropolitan or rural residence does not appear to influence either awareness or concern to any significant degree. Fourthly, whilst having a higher education strongly influences awareness of environmental impact of products, the same can not be said for concern of impact as models 3 and 4 reveal no statistically significant results for any of the education level variables. Finally, note how none of the employed occupation variables are significantly correlated with concern relative to the nonemployed (model 3). The only statistically significant relationship for the occupation variables is home makers who influence concern positively relative to the retired. 
Table 4.21: Results of multiple regression analyses covering concern of environmental impact of products (with controls). Europe, 2009

\begin{tabular}{|c|c|c|c|c|}
\hline Variable | & mode 11 & mode 12 & mode13 & mode14 \\
\hline $\begin{array}{l}\text { Cage } \\
\text { Cage2 }\end{array}$ & $.00562 * * *$ & $\begin{array}{r}.00511 * * * \\
-.00013 * * *\end{array}$ & $\begin{array}{r}.00457 * * * \\
-.00016 * * *\end{array}$ & $\begin{array}{l}.00419 * * * \\
-.00013 * *\end{array}$ \\
\hline female I & & & $.133 * * *$ & $.114 * * *$ \\
\hline $\begin{array}{l}\text { EDUCATION } \\
\text { No_fu11_time } \\
\text { Less_than_15 } \\
\text { Age_16_20 } \\
\text { Age_20p1us } \\
\text { Sti11_in_edu } \\
\text { Refusal (BASE) }\end{array}$ & & & $\begin{array}{l}.0671 \\
.127 \\
.118 \\
.165 \\
.129\end{array}$ & $\begin{array}{l}.0728 \\
.119 \\
.119 \\
.169 \\
.267\end{array}$ \\
\hline $\begin{array}{l}\text { OCCUPATION } \\
\text { Professiona1 } \\
\text { Executive } \\
\text { Middle_manag } \\
\text { Owner_manage } \\
\text { Manua } 1 \text { _worke } \\
\text { Home_maker } \\
\text { Student } \\
\text { Job_seeker } \\
\text { Retired (BASE) } \\
\text { Other_refuse }\end{array}$ & & & $\begin{array}{r}-.0799 \\
.0132 \\
-.0514 \\
-.032 \\
-.0297\end{array}$ & $\begin{array}{c}-.0821 \\
.0115 \\
-.0502 \\
-.0304 \\
-.0305 \\
.109 * \\
-.18 \\
-.115 \\
.0442\end{array}$ \\
\hline $\begin{array}{c}\text { RESIDENCE } \\
\text { metro } \\
\text { rura1 } \\
\text { urban (BASE) }\end{array}$ & & & $\begin{array}{l}-.0378 \\
-.0237\end{array}$ & $\begin{array}{l}-.0371 \\
-.0246\end{array}$ \\
\hline _cons | & $3.16 * * *$ & $3.21 * * *$ & $3.05 * * *$ & $3.04 * * *$ \\
\hline $\mathrm{N} \mathrm{I}$ & 25894 & 25894 & 25894 & 25894 \\
\hline
\end{tabular}

Source: Eurobarometer, 2009

Once again, including controls on education and occupation does not greatly affect the influence of age as the above Table 4.22 of estimates shows.

The now familiar continued rise in concern for product impacts with age also shows little change after introducing controls for education and occupation. This like the previous is an important result because it means that I can describe the relationship between awareness and age and concerns and age in chapter 5 when describing country effects without complicating matters by introducing controls. 
Table 4.22: Results of multiple regression analysis covering concern over the importance of environmental impact of products (with controls). Europe, 2009

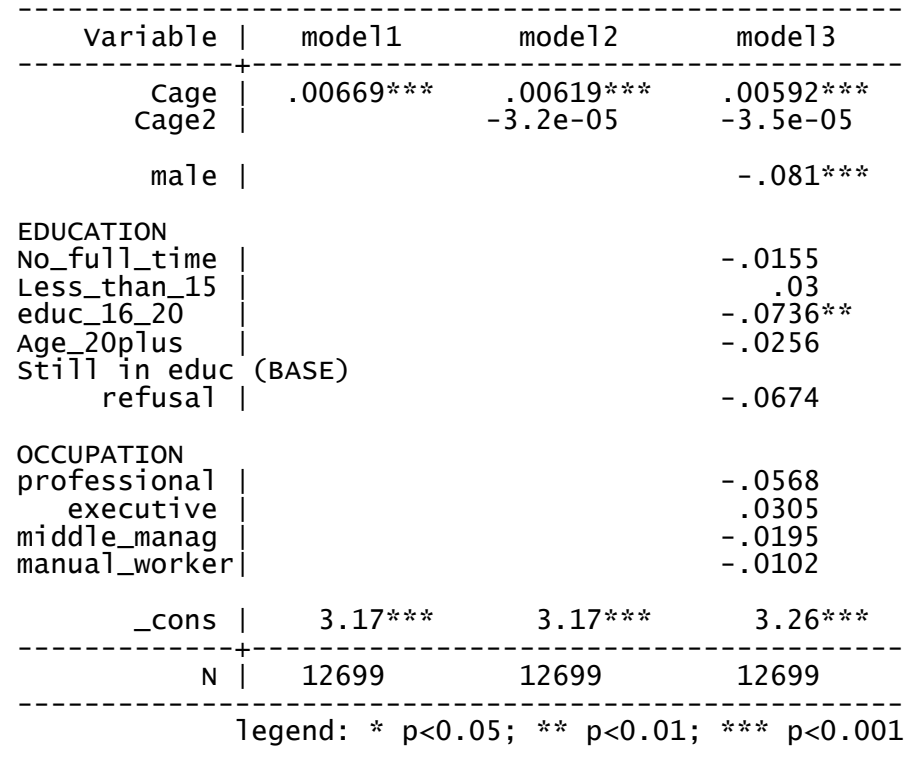

Source: Eurobarometer, 2009

Figure 4.10. Predicted level of concern over the importance of environmental impact of products across age with and without controlling for education and occupations. Europe 2009

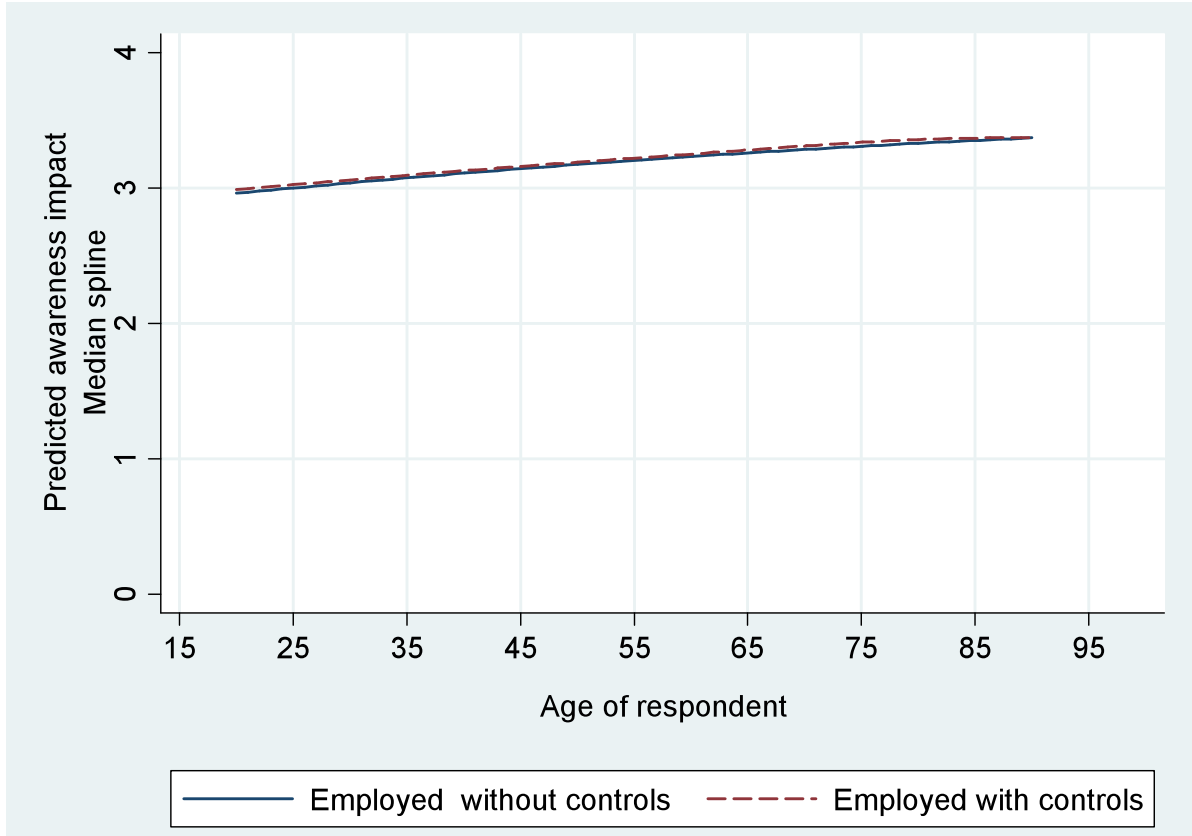

Source: Eurobarometer, 2009 


\subsection{Summary}

In summary, I began this chapter introducing each of the dependent variables and then demonstrated that the influence of age on awareness and concern is non-linear with respect to all - to varying degrees.

It was possible however that there were non-age specific features (e.g. being male or living in urban or rural or being highly educated) which could affect this, but more importantly there are events which take place at particular ages (such as being employed) which themselves could potentially raise or lower awareness.

The effect of adding controls - especially being employed and then being in certain occupations - was to remove some of the 'age effect', in particular it reduced some of the curvature. Thus being middle aged still raises awareness and did so partly because this stage of one's life is more likely to be associated with employment. The curve becomes even flatter (but higher) when just the employed are considered.

The results for concern of environmental impact suggest that the middle aged continue to show higher levels of awareness and recognition of the importance of product impact than the young. What does change when we confine the analysis to the employed is the negative effect on both of being older. Therefore, as far as the European sample as a whole is concerned, there appears to be empirical support for my thesis that environmental consciousness peaks in middle age. 


\section{Chapter 5. Inter-country variations in middle age greenness}

My analysis of survey responses by individuals across Europe in chapter 4 demonstrated the way awareness and concern of product's impact on the environment varied by age. In the case of awareness both the young and the old were relatively less aware than those in their $50 \mathrm{~s}$ and $60 \mathrm{~s}$. The same difference between the young and middle aged applied to concern of a products impact. Unlike their awareness however, concern did not decline among the older age groups. Both results demonstrated departures from many previous studies which argue for a decline in environmental consciousness from youth onwards.

My results for awareness and concern also remained resistant to the introduction of controls; the same relative age effects held up even when I controlled for life stage influences such as being employed and having higher education. Median average measures of awareness and concern predicted from the quadratic age model with controls when plotted against age, tracked those without controls very closely. In other words, regardless of education, occupation, gender and population density, respondents age continued to have a similar influence - rising then falling.

The age differences apparent when it came to awareness and concern transferred with some modifications across into peoples reactions to four policy initiatives: support for ecolabeling on products, mandatory labeling of a product's carbon footprint, awareness of the EU ecolabel, the Flower, and support for a voluntary environmental code of conduct/binding legislation. While not exhibiting the same difference between the middle age and other age groups the relative weight put on these responses did still vary significantly between young, middle and older consumers.

Of interest in this fifth chapter is the degree to which the patterns uncovered in chapter 4 continue to hold across the individual countries of Europe. I begin by simply describing the variation apparent in the survey responses - much as the EU commission report itself has done (The Gallup Organisation, 2009). I then add the 281 country dummy variables to the individual level equation reported in chapter 4 to see if there were noticeable country fixed effects - in addition to respondents age, 
gender, education etc. The answer is clear - countries do vary markedly in their levels of awareness and concern for product impact.

The country effects identified, while instructive, are limited in terms of what they tell. When estimated as fixed effects they simply indicate that on average one country exhibits a higher or lower level of awareness than another. Given my focus on the role of age, I actually want to learn more than that. I want to know whether, in addition to having a higher level of awareness overall, living in a particular country alters the rate at which awareness rises and falls with age. In other words, I want to know how stable the inverse $U$ shape in age is across the countries of Europe and how the relationship changes shape depending on that country's 'cultural' context.

Without this knowledge of the age variations in attitudes towards sustainable consumption across countries, there will remain problems in generalising from the Europe wide evidence. Ultimately policies need to be appropriate and agreed to by individual countries, even in the European Union. Countries which depart in the way the way people respond at different ages - in terms of awareness and appreciating the importance of product impact as well as the different policy initiatives - may imply the need for country specific modifications in the way these messages about sustainability get transmitted from one country to another. Such inter-country variations also beg a variety of other questions about why their residents might differ in their awareness and concerns over sustainability issues.

Having identified noticeable country effects below I then formalise the comparison by specifying and estimating a multilevel regression model. This modification to the regression model does two things. It recognises and specifically accounts for the fact that when people are clustered into groups like countries their responses are far less likely to be independent of one another. The autocorrelation generated by clustering or nesting is explicitly adjusted for in the multi level model (Bickel, 2007). The second and substantively important thing the multilevel model does is to allow me to test for the relative influence of what are called level 2 (country) effects on the estimates of both the level of awareness in the country (the intercept), how much awareness and concern rise with age and the degree to which they decline after middle age. 
The ability of the model to allow me to test whether both the intercepts of the quadratic age model and their slopes vary across the continent makes it appropriate for this kind of study - as previous applications elsewhere have shown (Subramanian et al. 2003; Weich et al. 2003). Having said this there are concerns in some quarters where multilevel models have been applied most notably in the public health field (Diez-Roux, 1998; Mitchell, 2001; Pickett and Perl, 2001). In contrast to the example of application of multilevel models in the public health field their application to the study of environmental attitudes has been very limited.

\subsection{Some Descriptive Results}

To being with, I will look at the variance in respondents awareness of environmental impact by country. The results in Table 5.1 clearly show that awareness does vary across Europe for there are marked differences in the distribution of response across the four possible answers to this first question.

Table 5.1: Percentage distribution of responses to level of awareness, by country. Europe, 2009

\begin{tabular}{|c|c|c|c|c|c|}
\hline $\begin{array}{l}\text { nation (archive } \\
\text { standard coding) }\end{array}$ & $\begin{array}{r}\text { Awareness } \\
1\end{array}$ & $\begin{array}{l}\text { about the } \\
\text { products be } \\
2\end{array}$ & or used & $\begin{array}{r}\text { impact of } \\
4 \text { । }\end{array}$ & Total \\
\hline $\begin{array}{r}\text { france } \\
\text { belgium } \\
\text { the netherlands } \\
\text { germany } \\
\text { italy } \\
\text { luxembourg } \\
\text { denmark } \\
\text { ireland } \\
\text { kingdom } \\
\text { greece } \\
\text { spain } \\
\text { portugal } \\
\text { finland } \\
\text { sweden } \\
\text { austria } \\
\text { (republic) } \\
\text { republic } \\
\text { estonia } \\
\text { hungary } \\
\text { latvia } \\
\text { lithuania } \\
\text { malta } \\
\text { poland } \\
\text { cyprus } \\
\text { czeciakia } \\
\text { slovenia } \\
\text { bulgaria } \\
\text { romania } \\
\text { croatia }\end{array}$ & $\begin{array}{r}7.93 \\
6.47 \\
2.81 \\
4.54 \\
13.31 \\
5.99 \\
7.85 \\
7.17 \\
5.38 \\
10.09 \\
12.10 \\
7.61 \\
4.52 \\
3.62 \\
2.84 \\
12.83 \\
10.36 \\
11.27 \\
7.73 \\
8.98 \\
12.78 \\
10.32 \\
6.79 \\
7.96 \\
4.33 \\
20.00 \\
12.95 \\
10.72\end{array}$ & $\begin{array}{l}13.76 \\
33.40 \\
40.02 \\
37.84 \\
29.33 \\
25.35 \\
46.32 \\
43.97 \\
43.35 \\
38.02 \\
40.42 \\
44.54 \\
49.45 \\
45.07 \\
31.14 \\
48.47 \\
33.40 \\
41.62 \\
36.55 \\
38.75 \\
38.96 \\
25.71 \\
28.98 \\
36.29 \\
28.93 \\
37.73 \\
34.84 \\
37.27\end{array}$ & $\begin{array}{l}43.57 \\
36.49 \\
52.56 \\
52.77 \\
41.53 \\
51.90 \\
43.50 \\
35.76 \\
37.97 \\
36.39 \\
32.56 \\
41.64 \\
41.61 \\
43.06 \\
61.76 \\
22.40 \\
43.26 \\
37.16 \\
46.18 \\
45.01 \\
41.21 \\
32.19 \\
39.72 \\
38.71 \\
39.11 \\
32.68 \\
27.34 \\
37.37\end{array}$ & $\begin{array}{r}34.74 \\
23.64 \\
4.61 \\
4.84 \\
15.83 \\
16.77 \\
2.32 \\
13.10 \\
13.30 \\
15.49 \\
14.92 \\
6.21 \\
4.42 \\
8.25 \\
4.26 \\
16.29 \\
12.98 \\
9.95 \\
9.54 \\
7.27 \\
7.06 \\
31.78 \\
24.52 \\
17.04 \\
27.62 \\
9.59 \\
24.87 \\
14.63\end{array}$ & $\begin{array}{r}100.00 \\
100.00 \\
100.00 \\
100.00 \\
100.00 \\
100.00 \\
100.00 \\
100.00 \\
100.00 \\
100.00 \\
100.00 \\
100.00 \\
100.00 \\
100.00 \\
100.00 \\
100.00 \\
100.00 \\
100.00 \\
100.00 \\
100.00 \\
100.00 \\
100.00 \\
100.00 \\
100.00 \\
100.00 \\
100.00 \\
100.00 \\
100.00\end{array}$ \\
\hline Total & 8.47 & 36.96 & 40.87 & 13.70 & 100.00 \\
\hline
\end{tabular}




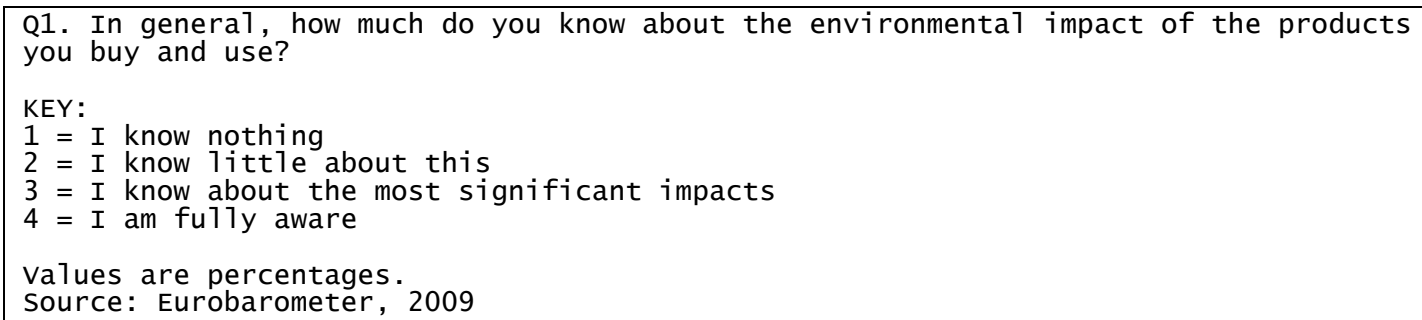

Levels of awareness in countries can vary almost ten fold at the extremes of the responses - in the proportion who "Know nothing" and six fold for "I am fully aware". However there is considerably less variation in the two middle columns of Table 5.1 above.

Whilst only 2.81 percent of Dutch citizens surveyed know nothing of the environmental impact of products bought and used, the proportion is much higher (20\%) amongst Bulgarians. The low extremes involve the Netherlands, Germany, Austria and Denmark. The results for France show that they are comparatively more knowledgeable concerning environmental impacts than the other countries in Europe. Over one third, or 34.74 percent of the 1006 French respondents said that they are fully aware of the impact that products have on the environment. This is in stark contrast to the Danish for example, where only 2.32 percent of respondents said they were fully aware. The extent to which this is picking up differences in knowledge as opposed to country different proclivities for under and over estimation is unclear.

The bulk of responses to awareness however are carried by the middle two responses and therefore if we compare countries on their average score (that is by taking the average of the responses weighted as 1,2,3 and 4 respectively) the variations do not appear so great, but they are present in the graph of differences from the European average in Figure 5.1. Even here however France shows $1 / 4$ of the scale higher response than the European average.

It is instructive to compute the country results for the environmental concern as well. The degree of variation across countries is also quite marked when it comes to judging environmental concern (see Table 5.2 below), varying from a about one quarter believing impact is very important (Estonia) through to 63.75 percent in Cyprus, albeit both are relatively small countries. 
Figure 5.1 Percentage distribution of responses to level of concern, by country. 2009

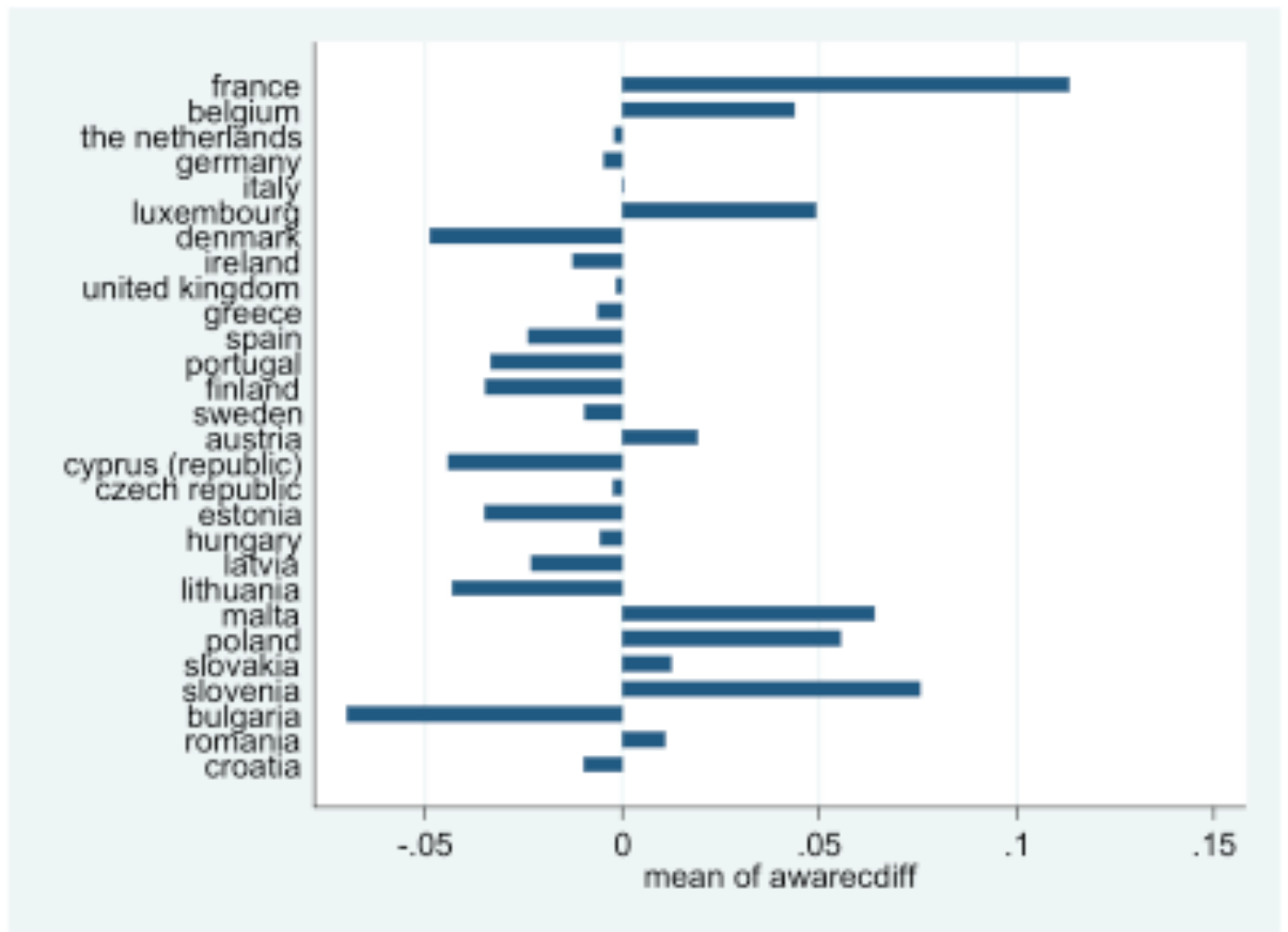

Source: Eurobarometer 2009

Note: The variable 'awarecdiff' is the average awareness score of each country minus the average awareness score of Europe as a whole. The awareness score is based on weights 1 to 4 assigned to the four responses 1 to 4 in question 1 .

It appears that European respondents are more concerned about the impact to the environment of products than they are actually aware of them, i.e. responses to question 2 have a higher average than question 1. From country to country though, this is not always the case. For example, France scores higher for awareness, but lower for concern relative to the overall mean. It seems French citizens are more aware of the external costs to the environment of product production and use, but are not so concerned about it. By contrast, respondents from Greece, Italy and Cyprus are more concerned than they are aware. Romania, Slovenia, Austria and to some extent, Luxembourg score above average for both awareness and concern. The Scandinavian countries in particular (Sweden, Finland and Denmark) as well as Latvia and to some extent, the UK, score below average for both awareness and concern. 
Table 5.2 Percentage distribution by response category Europe, 2009

\begin{tabular}{|c|c|c|c|c|c|}
\hline $\begin{array}{c}\text { nation (archive } \\
\text { standard coding) }\end{array}$ & \multicolumn{5}{|c|}{$\begin{array}{l}\text { Importance of the product's impact on the } \\
\text { environment when purchasing }\end{array}$} \\
\hline $\begin{array}{r}\text { france } \\
\text { belgium } \\
\text { the netherlands } \\
\text { germany } \\
\text { italy } \\
\text { luxembourg } \\
\text { denmark } \\
\text { ireland } \\
\text { kingdom } \\
\text { greece } \\
\text { spain } \\
\text { portugal } \\
\text { finland } \\
\text { sweden } \\
\text { austria } \\
\text { (republic) } \\
\text { republic } \\
\text { estonia } \\
\text { hungary } \\
\text { latvia } \\
\text { cypruted } \\
\text { czeania } \\
\text { malta } \\
\text { poland } \\
\text { slovakia } \\
\text { slovenia } \\
\text { bulgaria } \\
\text { romania } \\
\text { croatia }\end{array}$ & $\begin{array}{l}3.01 \\
3.40 \\
2.11 \\
1.73 \\
3.68 \\
1.40 \\
3.44 \\
4.28 \\
5.61 \\
3.05 \\
3.55 \\
1.94 \\
3.54 \\
2.73 \\
1.01 \\
3.05 \\
6.74 \\
5.00 \\
1.33 \\
6.69 \\
7.51 \\
4.44 \\
2.68 \\
5.28 \\
1.74 \\
8.50 \\
4.65 \\
7.26\end{array}$ & $\begin{array}{r}9.42 \\
6.60 \\
11.86 \\
10.79 \\
7.46 \\
6.39 \\
12.66 \\
8.98 \\
11.12 \\
5.19 \\
10.85 \\
17.09 \\
19.92 \\
13.56 \\
6.19 \\
6.52 \\
22.27 \\
17.08 \\
12.03 \\
19.26 \\
14.38 \\
9.88 \\
12.27 \\
15.94 \\
6.56 \\
11.16 \\
8.37 \\
10.18\end{array}$ & $\begin{array}{l}57.62 \\
44.95 \\
60.30 \\
54.58 \\
37.59 \\
52.30 \\
54.41 \\
47.49 \\
52.96 \\
32.38 \\
48.88 \\
42.27 \\
61.58 \\
57.29 \\
45.94 \\
26.68 \\
43.72 \\
53.75 \\
51.58 \\
46.24 \\
37.21 \\
39.52 \\
49.79 \\
46.48 \\
46.46 \\
43.89 \\
30.58 \\
42.14\end{array}$ & $\begin{array}{l}29.96 \\
45.05 \\
25.73 \\
32.89 \\
51.28 \\
39.92 \\
29.48 \\
39.25 \\
30.31 \\
59.37 \\
36.71 \\
38.69 \\
14.96 \\
26.42 \\
46.86 \\
63.75 \\
27.27 \\
24.17 \\
35.07 \\
27.81 \\
40.91 \\
46.17 \\
35.26 \\
32.30 \\
45.23 \\
36.45 \\
56.40 \\
40.42\end{array}$ & $\begin{array}{l}100.00 \\
100.00 \\
100.00 \\
100.00 \\
100.00 \\
100.00 \\
100.00 \\
100.00 \\
100.00 \\
100.00 \\
100.00 \\
100.00 \\
100.00 \\
100.00 \\
100.00 \\
100.00 \\
100.00 \\
100.00 \\
100.00 \\
100.00 \\
100.00 \\
100.00 \\
100.00 \\
100.00 \\
100.00 \\
100.00 \\
100.00 \\
100.00\end{array}$ \\
\hline Total & 3.94 & 11.79 & 47.19 & 37.08 & 100.00 \\
\hline
\end{tabular}

Q2a. How important is the product's impact on the environment?

KEY:

$1=$ Not at al1 important

$2=$ Rather not important

3 = Rather important

4 = very important

values are percentages

Source: Eurobarometer, 2009

Calculating the average of the weighted responses in the same way as for the awareness question yields Figure 5.2 which differs in a number of respects from the differences apparent in the awareness question.

Comparisons between countries on the basis of responses to survey questions is relatively common in the literature. More often than not they are simply averages of responses as those I've used above. The problem with drawing inferences about country differences from averages like these is that there is no adjustment for the fact that countries also vary in their mix of attributes of individuals many of which which are correlated with such differences. If the young show relatively low levels of awareness of the environmental impact of the products they buy for example with a relatively large youth population and will, other things equal, display relatively lower 
levels of awareness. The same point applies to other characteristics of countries which alter responses such as level of education or occupational mix, and so on.

Figure 5.2: Differences in environmental impact scores by country. Europe, 2009

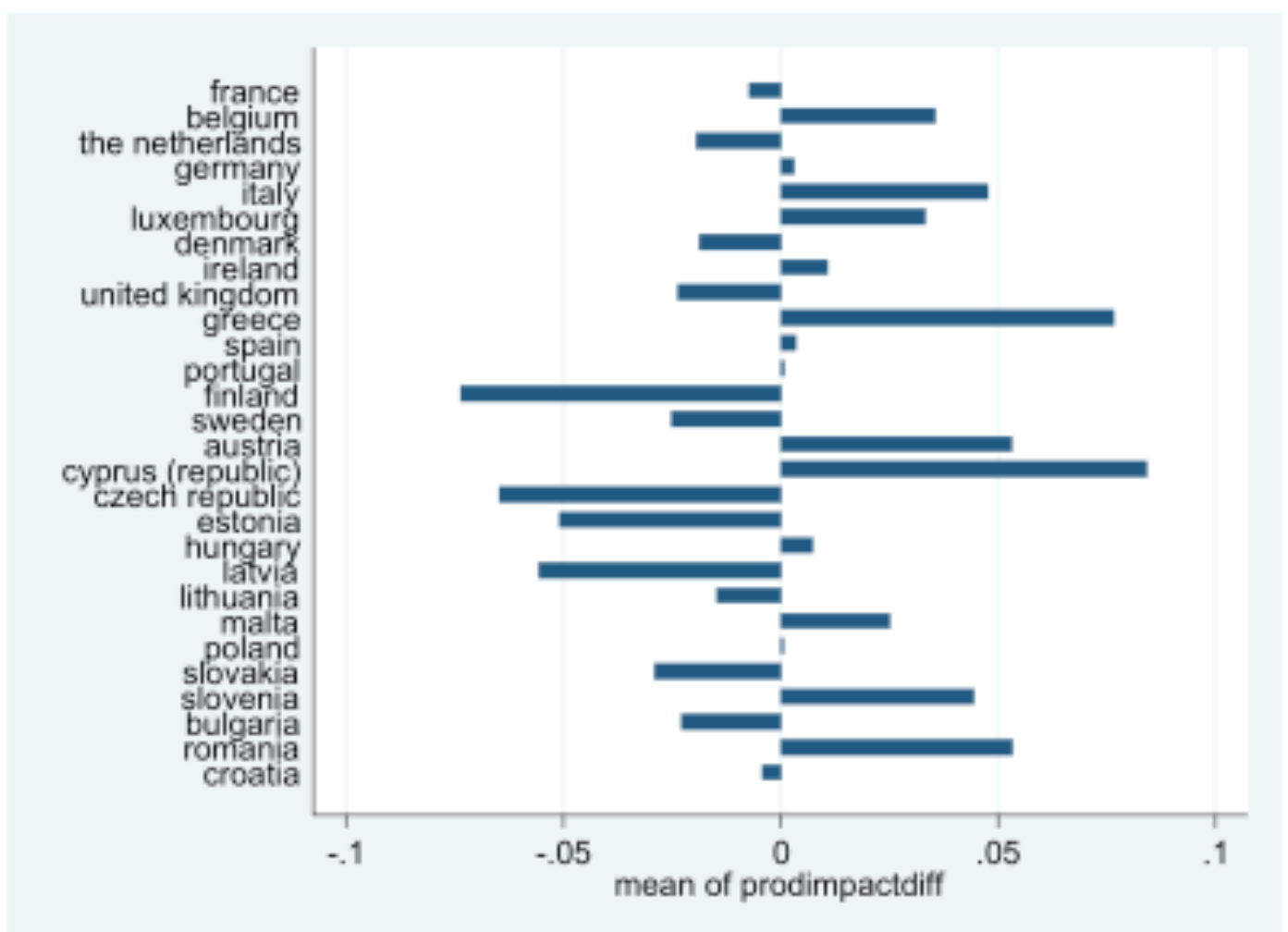

Source: Eurobarometer Survey, 2009

Figure 5.3 shows the distribution of respondents age by country. The median in these country box plots can be compared to the overall median represented here by the overall median (the vertical line). Sampled respondents from Greece and Spain exhibit particularly low median ages - around the early/mid 40s while Belgium and Slovenia have much higher median ages - around the mid 50s. Although the medians differ, the proportions within the inter-quartile range (the boxes) are similar.

The fact that respondents characteristics differ by country suggests that if I am to identify country effects per se, it is much more meaningful to begin with the individual level models of awareness and concern ( which explicitly includes the age and other characteristics of individuals) and then ask whether country effects matter over and above these individual effects. 
Figure 5.3: The distribution of ages by country (ages 15+). Europe 2009.

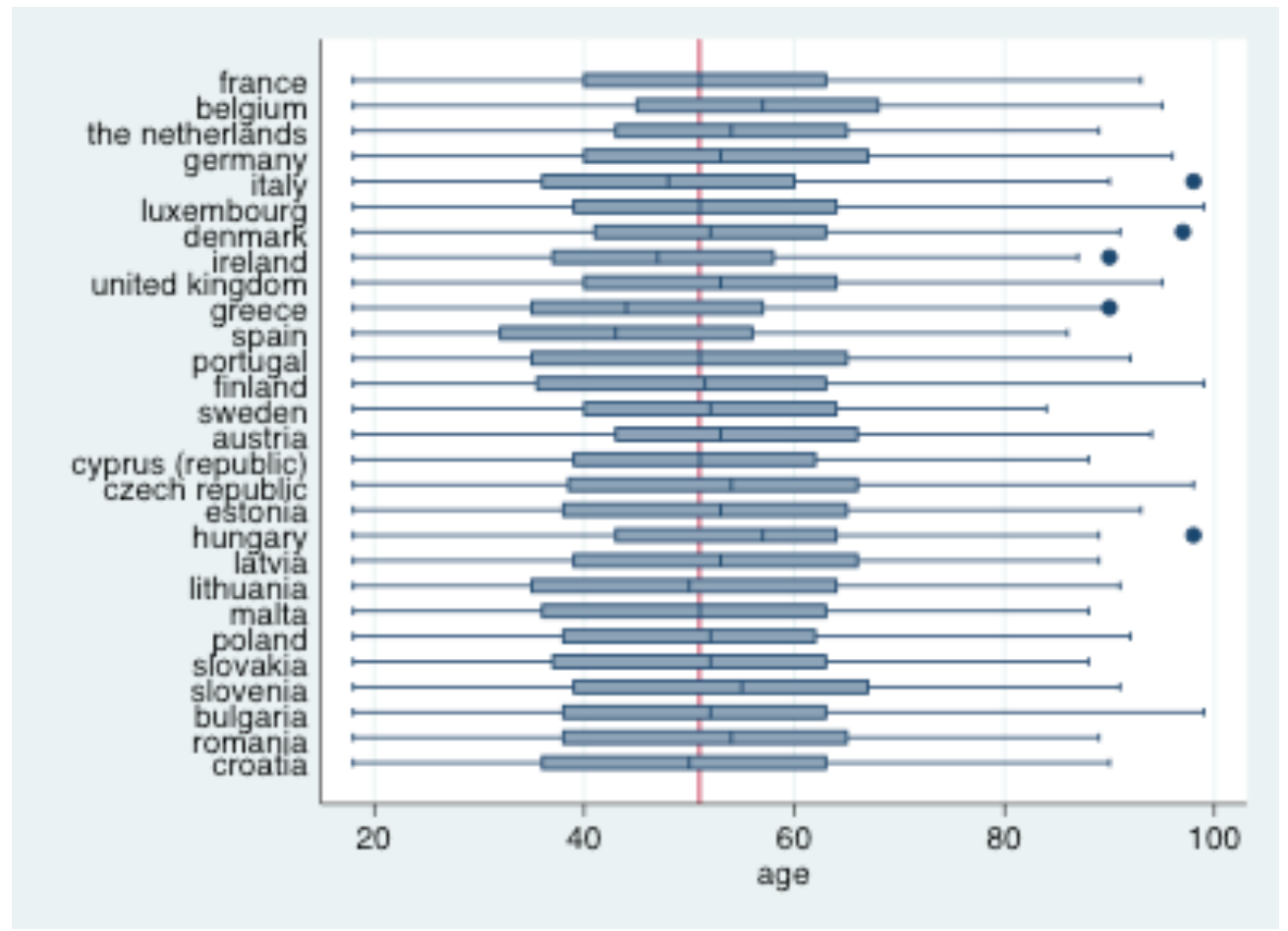

Source: Eurobarometer, 2009

The characteristics of the European sample as a whole were presented in Table 3.2 in chapter 3 and need not be repeated here. Suffice it to recall that the average age of the sampled population is just under 50 years of age, and that under 40 percent of respondents were men. Only 1.56 percent had no fulltime education although about 14 percent had less than fifteen years. Most had been in 'school' between 16 and 20 years (43.4 percent) and a further third for 20 years or more (32.2 percent). Just over seven percent were still in education. Less than half the sample were employed, a surprisingly lower participation rate which no doubt reflects the sample's bias towards the retired - those who have time to answer survey questions.

Of those that were employed almost 10 percent were in Professional or Executive positions, a further 30 percent were in managerial positions over various levels. Of those not working the vast majority were retired. Of the remainder most were homemakers, students, job seekers or other. Finally, almost 20 percent lived in metropolitan centres, two thirds in 'urban' and a remaining third in 'rural' areas. 
Table 5.3 Ordinary least squares model of awareness based on individual attributes alone. Europe, 2009

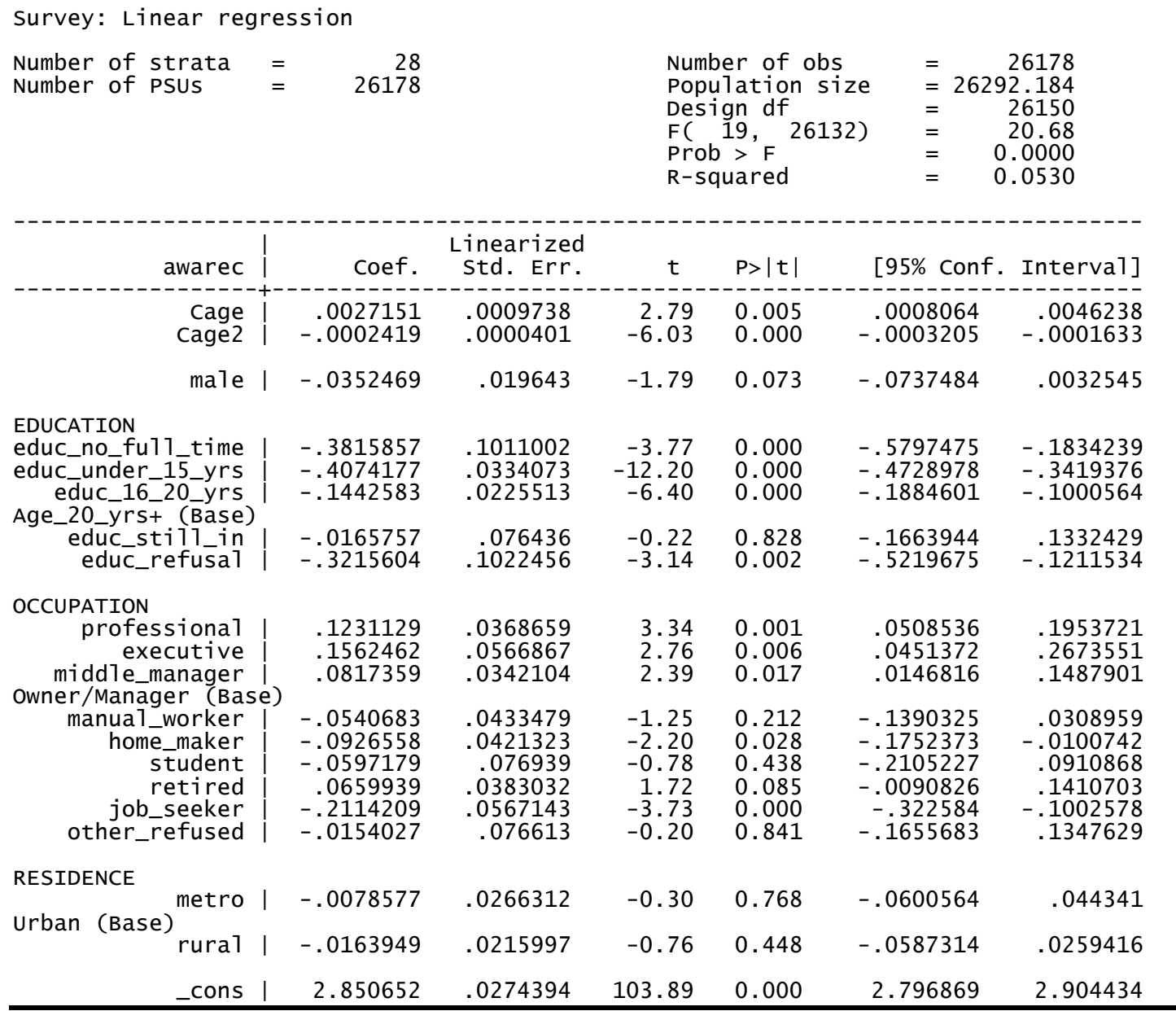

Source: Eurobarometer, 2009

Estimates from the model of awareness applied to individuals in the full sample are shown in Table 5.3. As discovered in chapter 4, the quadratic age effect remains strong even with the above controls, with awareness being lowest for youth, climbing to a maximum among the middle age then declining in older age. As noted in chapter 4, men tend to show lower awareness although their level is not quite significantly different from women (once I adjust for the higher standard errors results from the sample design). Awareness clearly rises with education with the biggest gap separating those who finished education at less than fifteen years and those that finished at age twenty or above. Even controlling for education, professionals and executives have higher levels of awareness (although the magnitudes are noticeably less than education effects per se). Of those outside the paid labour force, home 
makers and job seekers display lower levels of awareness. The type of settlement appears to have little effect.

Table 5.4 Ordinary least squares model of awareness based on individual attributes plus country fixed effects. Europe, 2009

\begin{tabular}{|c|c|c|c|c|c|c|}
\hline \multicolumn{3}{|c|}{$\begin{array}{llr}\text { Survey: Linear regression } & \\
\text { Number of strata } & = & 28 \\
\text { Number of PSUs } & = & 26178\end{array}$} & \multicolumn{2}{|c|}{$\begin{array}{l}\text { Number of obs } \\
\text { Population size } \\
\text { Design df } \\
\text { F( 44, 26107) } \\
\text { Prob> F } \\
\text { R-squared }\end{array}$} & \multicolumn{2}{|c|}{$\begin{array}{lr}= & 26178 \\
= & 26292.184 \\
= & 26150 \\
= & 27.81 \\
= & 0.0000 \\
= & 0.0940\end{array}$} \\
\hline awarec & Coef. & $\begin{array}{l}\text { Linearized } \\
\text { Std. Err. }\end{array}$ & $\mathrm{t}$ & $P>|t|$ & [95\% Conf. & Interva1] \\
\hline $\begin{array}{l}\text { Cage } \\
\text { Cage2 }\end{array}$ & $\begin{array}{r}.0036342 \\
-.0002562\end{array}$ & $\begin{array}{l}.0009575 \\
.000039\end{array}$ & $\begin{array}{r}3.80 \\
-6.56\end{array}$ & $\begin{array}{l}0.000 \\
0.000\end{array}$ & $\begin{array}{r}.0017574 \\
-.0003327\end{array}$ & $\begin{array}{r}.0055111 \\
-.0001797\end{array}$ \\
\hline male I & -.0277661 & .0190816 & -1.46 & 0.146 & -.0651672 & .0096349 \\
\hline $\begin{array}{l}\text { educ_no_fu11_t e } \\
\text { educ_under_15_ s } \\
\text { educ_16_20_yrs } \\
\text { ede_20+(BASE) }\end{array}$ & $\begin{array}{l}-.3506513 \\
-.3860427 \\
-.1405956\end{array}$ & $\begin{array}{l}.1038767 \\
.0339103 \\
.0220205\end{array}$ & $\begin{array}{r}-3.38 \\
-11.38 \\
-6.38\end{array}$ & $\begin{array}{l}0.001 \\
0.000 \\
0.000\end{array}$ & $\begin{array}{l}.5542554 \\
-.4525088 \\
-.183757\end{array}$ & $\begin{array}{l}-.1470472 \\
-.3195766 \\
-.0974342\end{array}$ \\
\hline $\begin{array}{r}\text { educ_sti11_in } \\
\text { educ_refusal }\end{array}$ & $\begin{array}{r}.0010562 \\
-.31553\end{array}$ & $\begin{array}{l}.0758521 \\
.0996348\end{array}$ & $\begin{array}{r}0.01 \\
-3.17\end{array}$ & $\begin{array}{l}0.989 \\
0.002\end{array}$ & $\begin{array}{r}-.147618 \\
-.5108196\end{array}$ & $\begin{array}{r}.1497305 \\
-.1202403\end{array}$ \\
\hline $\begin{array}{r}\text { professional } \\
\text { executive } \\
\text { middle_manager }\end{array}$ & $\begin{array}{l}.1690447 \\
.1815528 \\
.0593017\end{array}$ & $\begin{array}{l}.0366958 \\
.0568391 \\
.0322585\end{array}$ & $\begin{array}{l}4.61 \\
3.19 \\
1.84\end{array}$ & $\begin{array}{l}0.000 \\
0.001 \\
0.066\end{array}$ & $\begin{array}{r}.097119 \\
.070145 \\
-.0039267\end{array}$ & $\begin{array}{l}.2409704 \\
.2929605 \\
.1225301\end{array}$ \\
\hline $\begin{array}{r}\text { Owner/Manager (BASE } \\
\text { manual_worker } \\
\text { home_maker } \\
\text { student } \\
\text { retired } \\
\text { job_seeker } \\
\text { other_refused }\end{array}$ & $\begin{array}{r}\text { E) } \\
-.0760984 \\
-.0562339 \\
-.0018054 \\
.0271688 \\
-.1546111 \\
.0086414\end{array}$ & $\begin{array}{l}.0428325 \\
.0418034 \\
.0756269 \\
.0376932 \\
.0565354 \\
.0759116\end{array}$ & $\begin{array}{r}-1.78 \\
-1.35 \\
-0.02 \\
0.72 \\
-2.73 \\
0.11\end{array}$ & $\begin{array}{l}0.076 \\
0.179 \\
0.981 \\
0.471 \\
0.006 \\
0.909\end{array}$ & $\begin{array}{r} \\
.1600524 \\
-.1381708 \\
. .1500383 \\
. .0467119 \\
-.2654236 \\
-.1401494\end{array}$ & $\begin{array}{r}.0078555 \\
.025703 \\
.1464275 \\
.1010496 \\
-.0437985 \\
.1574322\end{array}$ \\
\hline $\begin{array}{r}\text { France } \\
\text { Belgium } \\
\text { Netherlands }\end{array}$ & $\begin{array}{r}.482212 \\
. .1731622 \\
-.0107638\end{array}$ & $\begin{array}{l}.0393567 \\
.0440893 \\
.0330611\end{array}$ & $\begin{array}{r}12.25 \\
3.93 \\
-0.33\end{array}$ & $\begin{array}{l}0.000 \\
0.000 \\
0.745\end{array}$ & $\begin{array}{r}.4050706 \\
.0867447 \\
. .0755654\end{array}$ & $\begin{array}{l}.5593534 \\
.2595797 \\
.0540379\end{array}$ \\
\hline $\begin{array}{r}\text { Base (Germany } \\
\text { Italy } \\
\text { Luxembourg } \\
\text { Denmark } \\
\text { Ireland } \\
\text { United_Kingdom } \\
\text { Greece } \\
\text { Spain } \\
\text { Portugal } \\
\text { Finland } \\
\text { Sweden } \\
\text { Austria } \\
\text { Cyprus } \\
\text { Czech_Republic } \\
\text { Estonia } \\
\text { Hungary } \\
\text { Latvia } \\
\text { Lithuania } \\
\text { Malta } \\
\text { Poland } \\
\text { Slovakia } \\
\text { Slovenia } \\
\text { Bulgaria } \\
\text { Romania } \\
\text { Croatia }\end{array}$ & $\begin{array}{r}.0628955 \\
.1728146 \\
-.2117689 \\
-.0698911 \\
.0271767 \\
-.002391 \\
-.0095713 \\
.063102 \\
-.149383 \\
-.0556615 \\
.1254326 \\
-.1806958 \\
-.0621489 \\
-.0359568 \\
.0091719 \\
-.1009058 \\
-.2905601 \\
.3867749 \\
.1926397 \\
-.0212213 \\
.2913913 \\
-.2962297 \\
.0657756 \\
-.0040239\end{array}$ & $\begin{array}{l}.0467878 \\
.0452235 \\
.0352975 \\
.0381547 \\
.0349903 \\
.0390372 \\
.0389607 \\
.0389015 \\
.0321706 \\
.0319048 \\
.0342897 \\
.0494967 \\
.0465772 \\
.045839 \\
.0525546 \\
.0497944 \\
.0459792 \\
.052068 \\
.0426453 \\
.0431754 \\
.0373561 \\
.0408145 \\
.0511136 \\
.0372963\end{array}$ & $\begin{array}{r}1.34 \\
3.82 \\
-6.00 \\
-1.83 \\
0.78 \\
-0.06 \\
-0.25 \\
1.62 \\
-4.64 \\
-1.74 \\
3.66 \\
-3.65 \\
-1.33 \\
-0.78 \\
0.17 \\
-2.03 \\
-6.32 \\
7.43 \\
4.52 \\
-0.49 \\
7.80 \\
-7.26 \\
1.29 \\
-0.11\end{array}$ & $\begin{array}{l}0.179 \\
0.000 \\
0.000 \\
0.067 \\
0.437 \\
0.951 \\
0.806 \\
0.105 \\
0.000 \\
0.081 \\
0.000 \\
0.000 \\
0.182 \\
0.433 \\
0.861 \\
0.043 \\
0.000 \\
0.000 \\
0.000 \\
0.623 \\
0.000 \\
0.000 \\
0.198 \\
0.914\end{array}$ & $\begin{array}{l}.0288111 \\
.084174 \\
.2809539 \\
.1446764 \\
.0414062 \\
-.078906 \\
.0859364 \\
.0131471 \\
.2124392 \\
.1181967 \\
.0582231 \\
-.277712 \\
.1534429 \\
.1258037 \\
-.093838 \\
.1985055 \\
.3806819 \\
.2847188 \\
.1090526 \\
.1058475 \\
.2181713 \\
.3762283 \\
.0344098 \\
.0771268\end{array}$ & $\begin{array}{r}.1546022 \\
.2614551 \\
-.1425838 \\
.0048942 \\
.0957597 \\
.074124 \\
.0667939 \\
.1393512 \\
-.0863267 \\
.0068738 \\
.1926422 \\
-.0836796 \\
.029145 \\
.0538901 \\
.1121819 \\
-.0033061 \\
-.2004384 \\
.488831 \\
.2762268 \\
.0634049 \\
.3646113 \\
-.2162311 \\
.1659611 \\
.069079\end{array}$ \\
\hline _cons | & 2.756143 & .0323327 & 85.24 & 0.000 & 2.692769 & 2.819517 \\
\hline
\end{tabular}

Source:Eurobarometer,2009 
A common approach to identifying fixed effects of location has been to simply add country dummies to the above equation as I show in the following table. The presence of country effects actually strengths the differences between the age groups, i.e. exaggerating the effect of middle age greenness (as judged by the longer more significant coefficients on Cage2). On the whole however acknowledging the presence of countries does not change the signs and apart from the coefficient on students and other non-employed does not make a marked difference to the estimated effects of individual attributes.

As noticed already in the descriptive results, when it comes to country effects there are some quite major differences in awareness between countries (using Germany as the base). Once we control for attributes of individuals we find that France stands out as being particularly aware (followed by Malta and Slovenia). Those with relatively much lower levels of awareness include Denmark, Finland, Lithuania and Bulgaria.

In chapter 2 I reviewed a number of findings about the way awareness varied with levels of development and pollution. In particular, Inglehart (1995) argued that countries with higher levels of pollution are likely to be environmentally aware but in addition to this, as countries develop economically they increase their focus towards environmental preservation. Similarly, findings by Franzen and Meyer (2009) show that the most economically developed countries rate the highest on levels of environmental concern. A number of those generalizations can be tested against these European data by replacing country dummies with attributes of the countries themselves as shown in the following table.

Although replacing country fixed effects with characteristics of those countries actually lowers the variance explained it does give me some indication of the overall effect of those characteristics (see Table 5.6). For example awareness rises (at an increasing rate) with the proportionate increases in size of the country, (country_population), the natural log of the population size. The results also show that environmental awareness declines as $\mathrm{CO}^{2}$ emissions rise (country_co2_emmissions), a result consistent with findings of Franzen and Meyer (2009); high $\mathrm{CO}^{2}$ emissions are unlikely to be tolerated by a highly aware population. 
Table 5.5: Selected characteristics of countries in Europe, 2008-2009

\begin{tabular}{|l|l|l|l|l|l|}
\hline Country & $\begin{array}{l}\text { EU } \\
\text { Region }\end{array}$ & $\begin{array}{l}\text { GDP per } \\
\text { capita } \\
\text { \$USDP) }^{*}\end{array}$ & Population & $\begin{array}{l}\text { Unemploy } \\
\text { ment total } \\
\text { (\%of total } \\
\text { labour } \\
\text { force) }\end{array}$ & $\begin{array}{l}\text { CO2 } \\
\text { emissions } \\
\text { (metric } \\
\text { tons per } \\
\text { capita) }\end{array}$ \\
\hline Luxembourg & Western & 83,251 & 498,000 & 5.1 & 21.5 \\
\hline The Netherlands & Western & 40,736 & $16,559,000$ & 2.8 & 10.6 \\
\hline Ireland & Western & 39,643 & $4,412,000$ & 6.0 & 9.9 \\
\hline Austria & Western & 38,874 & $8,370,000$ & 3.8 & 8.1 \\
\hline Denmark & Western & 37,672 & $5,525,000$ & 3.3 & 8.4 \\
\hline Sweden & Western & 37,213 & $9,311,000$ & 6.1 & 5.3 \\
\hline Belgium & Western & 36,411 & $10,661,000$ & 7.0 & 9.8 \\
\hline Germany & Western & 35,977 & $82,405,000$ & 7.5 & 9.6 \\
\hline Finland & Eastern & 35,656 & $5,342,000$ & 6.3 & 10.6 \\
\hline United Kingdom & Western & 35,145 & $61,652,000$ & 5.3 & 8.5 \\
\hline France & Western & 33,349 & $62,445,000$ & 7.4 & 5.9 \\
\hline Italy & Western & 32,413 & $60,249,000$ & 6.7 & 7.4 \\
\hline Spain & Western & 32,262 & $45,638,000$ & 11.3 & 7.2 \\
\hline Cyprus & Eastern & 30,728 & 803,000 & 3.8 & 7.9 \\
\hline Greece & Eastern & 28,883 & $11,327,000$ & 7.7 & 8.7 \\
\hline Slovenia & Eastern & 27,499 & $2,024,000$ & 4.4 & 8.5 \\
\hline Czech Republic & Eastern & 25,572 & $10,440,000$ & 4.4 & 11.2 \\
\hline Malta & Eastern & 25,319 & 415,000 & 5.8 & 6.2 \\
\hline Portugal & Western & 25,055 & $10,657,000$ & 7.6 & 5.3 \\
\hline Slovakia & Eastern & 22,806 & $5,452,000$ & 9.6 & 6.9 \\
\hline Croatia & Eastern & 20,037 & $4,411,000$ & 8.3 & 5.3 \\
\hline Hungary & Eastern & 19,939 & $10,002,000$ & 7.8 & 5.4 \\
\hline Estonia & Eastern & 19,878 & $1,342,000$ & 5.5 & 13.6 \\
\hline Poland & Eastern & 18,921 & $38,249,000$ & 7.1 & 8.3 \\
\hline Lithuania & Eastern & 17,059 & $3,341,000$ & 5.8 & 4.5 \\
\hline Latvia & Eastern & 16,166 & $2,261,000$ & 7.5 & 3.3 \\
\hline Romania & Eastern & 14,216 & $21,537,000$ & 5.8 & 4.4 \\
\hline Bulgaria & Eastern & 13,764 & $7,543,000$ & 5.6 & 6.6 \\
\hline Average & & 30,159 & $17,959,679$ & 6 & 8 \\
\hline Minimum & & 13,764 & 415,000 & 3 & 3 \\
\hline Maximum & 83,251 & $82,405,000$ & 11 & 22 \\
\hline & & & & \\
\hline
\end{tabular}

\footnotetext{
* 2009 Data for GDP per capita (PPP), \$USD sourced from UNESCO Institute for Statistics (2012) [online] available from http://stats.uis.unesco.org/unesco/TableViewer/document.aspx?ReportId=198\&IF Language=eng † 2008 Data sourced from The World Bank (2012) [Online] available from http://data.worldbank.org/indicator/EN.ATM.CO2E.PC [accessed on the 24th January, 2012]
} 
Table 5.6 The influence of country characteristics on awareness, controlling for attributes of respondents. Europe, 2009

\begin{tabular}{|c|c|c|c|c|c|c|c|}
\hline \multicolumn{8}{|c|}{ Survey: Linear regression } \\
\hline $\begin{array}{l}\text { Number of strata } \\
\text { Number of PSUs }\end{array}$ & & $\begin{array}{r}28 \\
26178\end{array}$ & & \multicolumn{2}{|c|}{$\begin{array}{l}\text { Number of obs } \\
\text { Population size } \\
\text { Design df } \\
\text { F( 21, 26130) } \\
\text { Prob > F } \\
\text { R-squared }\end{array}$} & \multicolumn{2}{|c|}{$\begin{array}{lr}= & 26178 \\
= & 26292.184 \\
= & 26150 \\
= & 30.32 \\
= & 0.0000 \\
= & 0.0652\end{array}$} \\
\hline awarec & & coef. & $\begin{array}{l}\text { Linearized } \\
\text { Std. Err. }\end{array}$ & $t$ & $P>|t|$ & {$[95 \%$ Conf } & Interva1] \\
\hline $\begin{array}{r}\text { Cage } \\
\text { cage2 }\end{array}$ & & $\begin{array}{r}.0028651 \\
-.0002499\end{array}$ & .0009662 & $\begin{array}{r}2.97 \\
-6.30\end{array}$ & $\begin{array}{l}0.003 \\
0.000\end{array}$ & $\begin{array}{r}.0009712 \\
-.0003276\end{array}$ & $\begin{array}{r}.0047589 \\
-.0001721\end{array}$ \\
\hline male & & -.0367379 & .0194352 & -1.89 & 0.059 & -.0748319 & .001356 \\
\hline $\begin{array}{r}\text { educ_no_fu11_time } \\
\text { educ_under_15_yrs } \\
\text { educ_16_20_yrs } \\
\text { educ_sti1 } 1 \text { in } \\
\text { educ_refusal }\end{array}$ & & $\begin{array}{l}-.3885626 \\
-.4294147 \\
-.1455434 \\
-.0018814 \\
-.3169324\end{array}$ & $\begin{array}{l}.1019889 \\
.0330535 \\
.022171 \\
.0759947 \\
.0991044\end{array}$ & $\begin{array}{r}-3.81 \\
-12.99 \\
-6.56 \\
-0.02 \\
-3.20\end{array}$ & $\begin{array}{l}0.000 \\
0.000 \\
0.000 \\
0.980 \\
0.001\end{array}$ & $\begin{array}{l}-.5884664 \\
-.4942013 \\
-.1889998 \\
-.1508351 \\
-.5111824\end{array}$ & $\begin{array}{r}-.1886587 \\
-.3646281 \\
-.1020871 \\
.1470722 \\
-.1226825\end{array}$ \\
\hline $\begin{array}{r}\text { professional } \\
\text { executive } \\
\text { middle_manager } \\
\text { manua1_worker } \\
\text { home_maker } \\
\text { student } \\
\text { retired } \\
\text { job_seeker } \\
\text { other_refused }\end{array}$ & & $\begin{array}{r}.1268503 \\
.1688376 \\
.0779513 \\
-.0567595 \\
-.0916771 \\
-.0480425 \\
.0672632 \\
-.1948782 \\
-.0017086\end{array}$ & $\begin{array}{l}.0364375 \\
.0566924 \\
.0333906 \\
.0432754 \\
.0420694 \\
.0761849 \\
.0379726 \\
.0567712 \\
.0776722\end{array}$ & $\begin{array}{r}3.48 \\
2.98 \\
2.33 \\
-1.31 \\
-2.18 \\
-0.63 \\
1.77 \\
-3.43 \\
-0.02\end{array}$ & $\begin{array}{l}0.000 \\
0.003 \\
0.020 \\
0.190 \\
0.029 \\
0.528 \\
0.077 \\
0.001 \\
0.982\end{array}$ & $\begin{array}{r}.0554307 \\
.0577173 \\
.012504 \\
-.1415816 \\
-.1741354 \\
-.197369 \\
-.0071652 \\
-.3061529 \\
-.1539504\end{array}$ & $\begin{array}{r}.1982699 \\
.2799578 \\
.1433987 \\
.0280627 \\
-.0092189 \\
.1012841 \\
.1416915 \\
-.0836035 \\
.1505333\end{array}$ \\
\hline $\begin{array}{r}\text { country_populatio } \\
\text { country_co2_emmis } \\
\text { country_gdp } \\
\text { country unemploym }\end{array}$ & & $\begin{array}{r}.065669 \\
-.0486676 \\
4.48 \mathrm{e}-06 \\
-.0125928\end{array}$ & $\begin{array}{r}.0077343 \\
.005642 \\
1.42 \mathrm{e}-06 \\
.0050323\end{array}$ & $\begin{array}{r}8.49 \\
-8.63 \\
3.15 \\
-2.50\end{array}$ & $\begin{array}{l}0.000 \\
0.000 \\
0.002 \\
0.012\end{array}$ & $\begin{array}{r}.0505093 \\
-.0597262 \\
1.69 \mathrm{e}-06 \\
-.0224563\end{array}$ & $\begin{array}{r}.0808287 \\
-.037609 \\
7.27 \mathrm{e}-06 \\
-.0027293\end{array}$ \\
\hline _cons & & 2.036631 & .1183926 & 17.20 & 0.000 & 1.804575 & 2.268687 \\
\hline
\end{tabular}

Source: Eurobarometer, 2009

Countries with higher levels of income per capita (country_gdp) show higher levels of awareness again as Franzen and Meyer (2009) suggest. Finally, awareness is lower in countries with higher levels of unemployment perhaps reflecting greater preoccupation with simply making ends meet. Each of these results applies after controlling for the gender, age, education and employment characteristics of the respondents, almost all of which have statistically significant effects of their own on the level of environmental awareness.

In summary, there are two levels of influence on awareness - those which can be attributed to the characteristics of the individual, and a second level reflecting the economic, social and institutional context in which they live. The presence of context effects where groups of individuals share common opportunities and constraints by virtue of citizenship in a particular country is very common. The multilevel perspective is a used way of thinking about environmental awareness especially in a 
Union which is trying to increase awareness of sustainability issues. Country effects matter in explanatory terms, but they also matter from a political and implementation point of view.

\subsection{A multilevel model of environmental awareness}

Multilevel (or mixed-effects) modeling is basically regression analysis allowing two kinds of effects, so called fixed effects, the intercepts and slopes that apply to the sample as a whole, and random effects, the predicted intercepts and slopes that vary across the subgroups of the sample (countries in my case).

It is easier to illustrate application of the multi-level method than to explain it technically (Hamilton, 2009; Rabe-Hesketh and Skrondal, 2008). I'll illustrate in terms of the thesis I am advancing namely that awareness peaks in middle age. I want to ask whether the specific nature of this relationship (the shape of the inverse $U$ curve) varies from country to country, and I firstly want to know whether allowing the intercepts of that relationship - the constant - to vary across the 28 countries, along with the slope(s) on the Cage and Cage ${ }^{2}$ variables actually adds to the explanatory power of the model. ${ }^{17}$

To illustrate I apply the basic age based model of environmental awareness and tested for country variation in both the intercepts and slopes in Table 5.7 and plotted their variation in Figure 5.4. The result in this case has awareness rising with age (but not significantly) given country effects, but awareness does decline into older age. At the same time, there is considerable variability in this relationship from one country to another. Knowledge of this variability is a valuable addition to what now becomes a multi-level model: the individuals occupy level 1 and their countries, level 2. (Further levels are possible but are not directly relevant here).

\footnotetext{
${ }^{17}$ One of the side benefits of multi-level modelling is that it reduces the problem of spatially correlated errors. These occur if there are commonalities or similarities that arise between people by virtue of being raised in the same country, a feature that compromises the assumption that individuals behave independently. Spatially correlated errors not surprisingly are endemic in geographical enquiry but are not always addressed. Doing so via multilevel modelling is one of the attractions of the method although not the main one.
} 
Table 5.7 Testing for the presence of country effects in when awareness peaks in middle age. A multilevel model

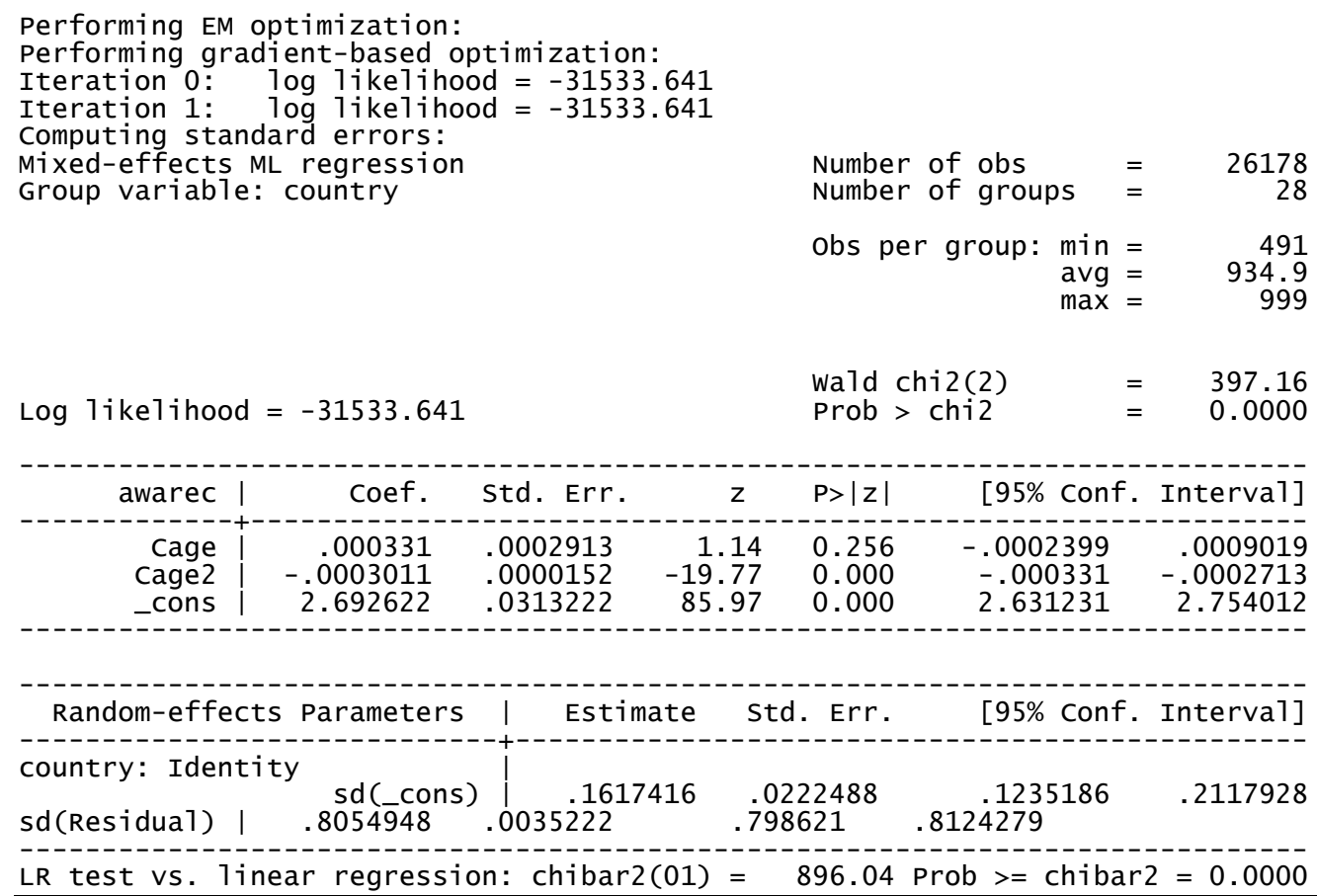

The results of applying the basic multilevel model is as follows. ${ }^{18}$ The upper section of this output table shows the fixed-effects part of my model. The model implies 28 separate intercepts, one for each country. However these intercepts are not directly estimated, instead, the lower section of the table gives their estimated standard deviation (.1617) along with the standard error (.0222) and the 95 percent confidence interval for that standard deviation. The parameters of the model from the table above are as follows (for the $i^{\text {th }}$ individual in the $j^{\text {th }}$ country); z statistics in parentheses.

$$
\begin{gathered}
\text { Awarec }_{i j}=2.692+.00033 \text { Cage }_{i j}-.0003 \text { Cage }_{i j}+u_{o j}+\varepsilon_{i j} \\
(85.97)(1.14) \\
(-19.77)
\end{gathered}
$$

Recall that the awareness (Awarec) scale runs from 1 to 4 and that the age variables are centred (i.e. the sample means have been subtracted from age to avoid what would

\footnotetext{
${ }^{18}$ One technical point which is unavoidable given the software I'm using, Stata12, is that while standard errors have been adjusted in the regressions hitherto based on the Eurobarometer's sampling design no such ready adjustments are available for the multilevel model in this particular package. In practice adjustment for the sampling frame inflates the standard errors and lowers the $t$ statistics. This remains the case in the multilevel case except that I'm unable to report the adjustment here. As a rule of thumb therefore in reading the multilevel results to follow read the $\mathrm{z}$ statistics as being about half of those reported. Substantively, in terms of what I conclude, with the large sample size, this technical issue doesn't make a great deal of difference.
} 
be a very high degree of collinearity between these terms, hence Cage and Cage ${ }^{2}$. The standard deviation of the random (country) intercept $u_{o}$ appears significantly different from zero, showing that the intercepts do vary from place to place. The standard deviation is almost eight standard errors from zero $(0.161 / 0.002)$ and its value is reasonably (although not overwhelmingly) substantial in the metric of my dependent variable, about $0.16 / 4$ points along the awareness scale. The likelihoodratio test reported on the output's final line confirms that this random-intercept model offers significant improvement over a linear regression model with fixed effects only $(p=0.0000)$.

Although the software I'm using does not directly calculate random effects for the countries, I can obtain the best linear unbiased predictions (BLUPS) of their effects and I have plotted them in Figure 5.4.

Figure 5.4: Variation in random intercepts predicted for countries based on the quadratic model of age effects on awareness of environmental impacts of purchased products. Europe, 2009

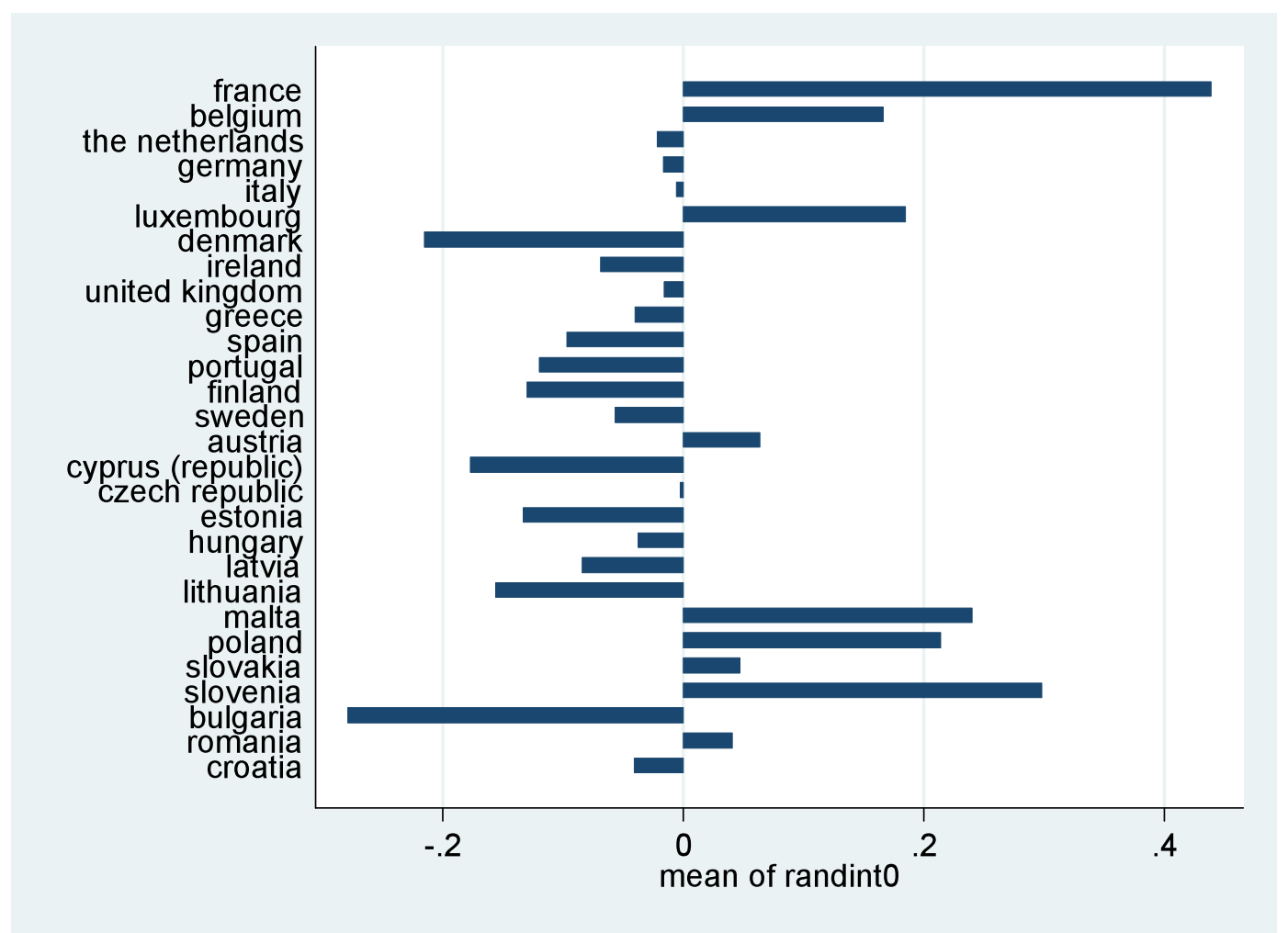

Source: Eurobarometer, 2009 
My interest in the way countries vary in the way awareness relates to age does not end with the intercept for that simply tells me that the convex curve relating awareness to age is higher in one country than another. In order to also capture the non-linear way in which awareness changes with age in the different countries I also need to predict the intercepts of the two age terms. I therefore specify a mixed model which includes not only the random intercepts $\left(u_{o j}\right)$ for each country $(j)$ but also their random slopes for both my predictors, Cage and Cage ${ }^{2}$.

The results of applying such a model shows that not only do the intercepts for the countries vary, sd(_cons) in the following table, but so too do the slopes of both age and $\operatorname{age}^{2}$ (in their centered form) $-\operatorname{sd}($ Cage), sd(Cage2). This means that no only do the age curves vary in their height $(0.159 / 0.022)$ but they also vary mostly in the rate at which awareness climbs through to middle age as well as the rate at which awareness declines in older age. In the case of both slopes, the standard deviation is many times the standard error, a ratio of $0.0035 / 0.00056$, in the case of Cage and $0.00008 / 0.00002$, in the case of Cage2.

Table 5.8: Testing for the presence of country effects in when awareness peaks in middle age along with the slopes. A multilevel model. Europe, 2009

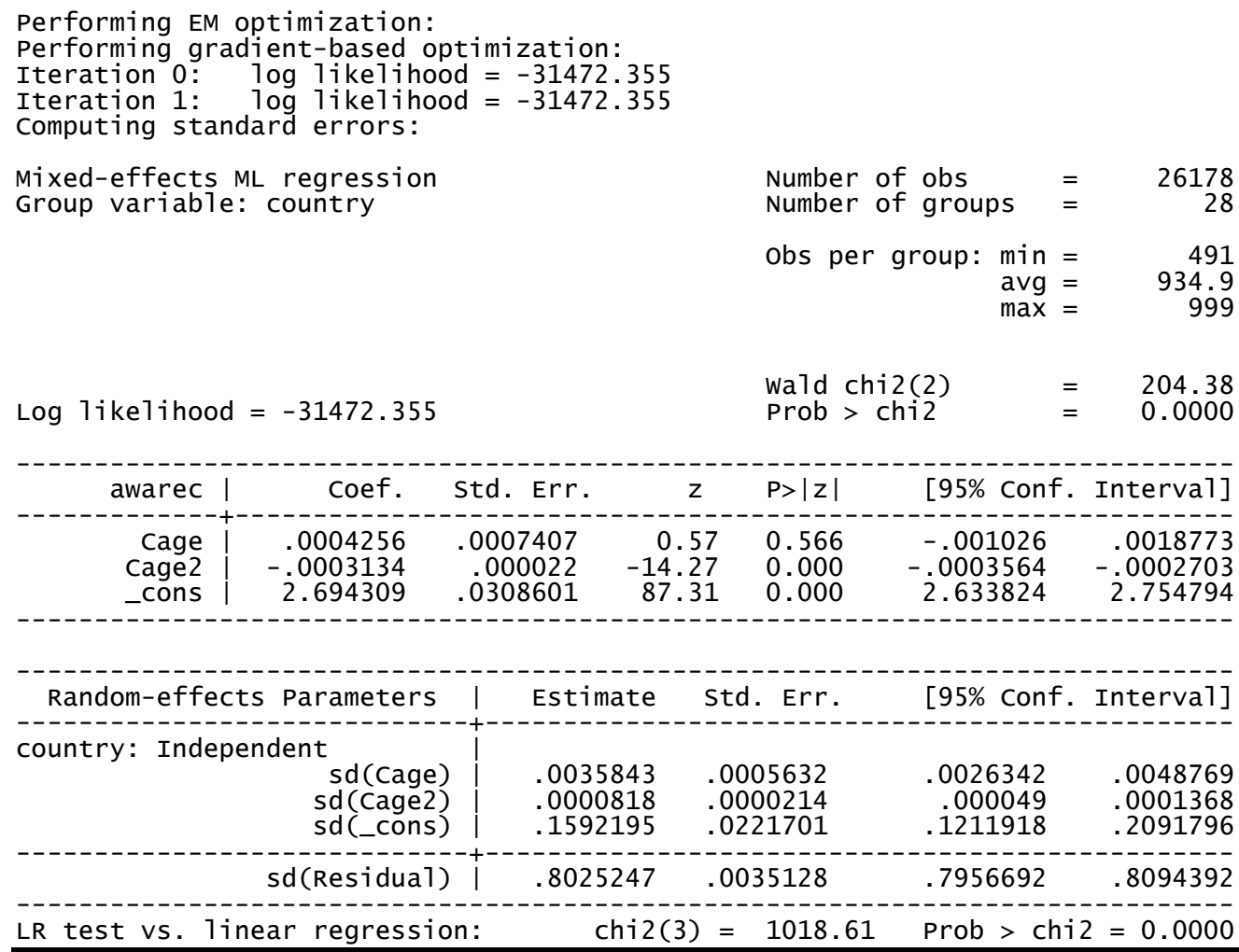

Source: Eurobarometer, 2009 
The above model however assumes that the intercepts and slopes are uncorrelated. To test this and see whether the correlation itself should be incorporated into the model I reran the model allowing for a nonzero covariance between the random effects. The result is Table 5.9.

Firstly, across countries the centred age and $\mathrm{age}^{2}$ are related. As one might expect the rate at which awareness rises to middle age in a country the more rapid is the rate at which awareness falls after middle age $($ corr(Cage, Cage2 $)=0.768 / 0.184)$.

Secondly, there clearly is covariance between the intercept and the slopes of the awareness age relationship. On the 'upside' of the awareness by age curve where awareness rises with age into the middle age years the intercept and slope are positively correlated (corr(Cage, cons $=0.28 / 0.19)$; the higher the level of awareness in a country, the greater the difference between the young and middle aged. Formal tests confirm these conclusions.

Table 5.9: Testing for the presence of country effects in when awareness peaks in middle age along with the slopes, allowing for correlation between the intercepts and slopes. A multilevel model. Europe, 2009

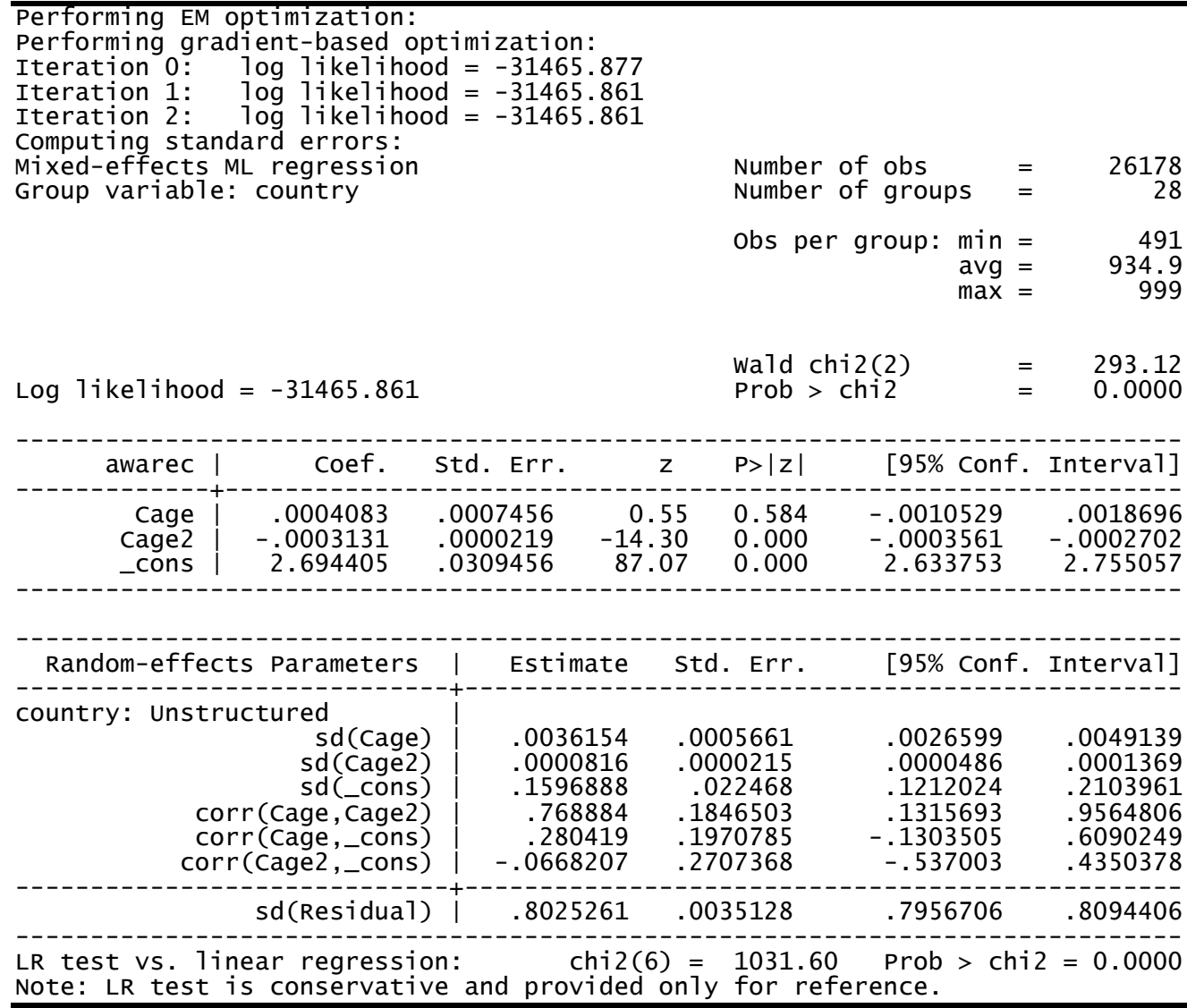

Source: Eurobarometer, 2009 
There is less evidence for any correlation between the intercept and the 'downside' of the slope where awareness declines with age from middle age onwards, corr(Cage2, cons ). Allowing for these correlation definitely improves the model (test results not shown).

The countries which exhibit steeper than average slopes (from youth to middle age) tend to be those with steeper downward slopes, from middle age to older respondents; compared the two figures below.

Figure 5.5: Variation in random slopes predicted for countries based on the quadratic model of age effects on awareness of environmental impacts of purchased products. Europe, 2009

\section{a.Inter country variations in the slope of Cage}

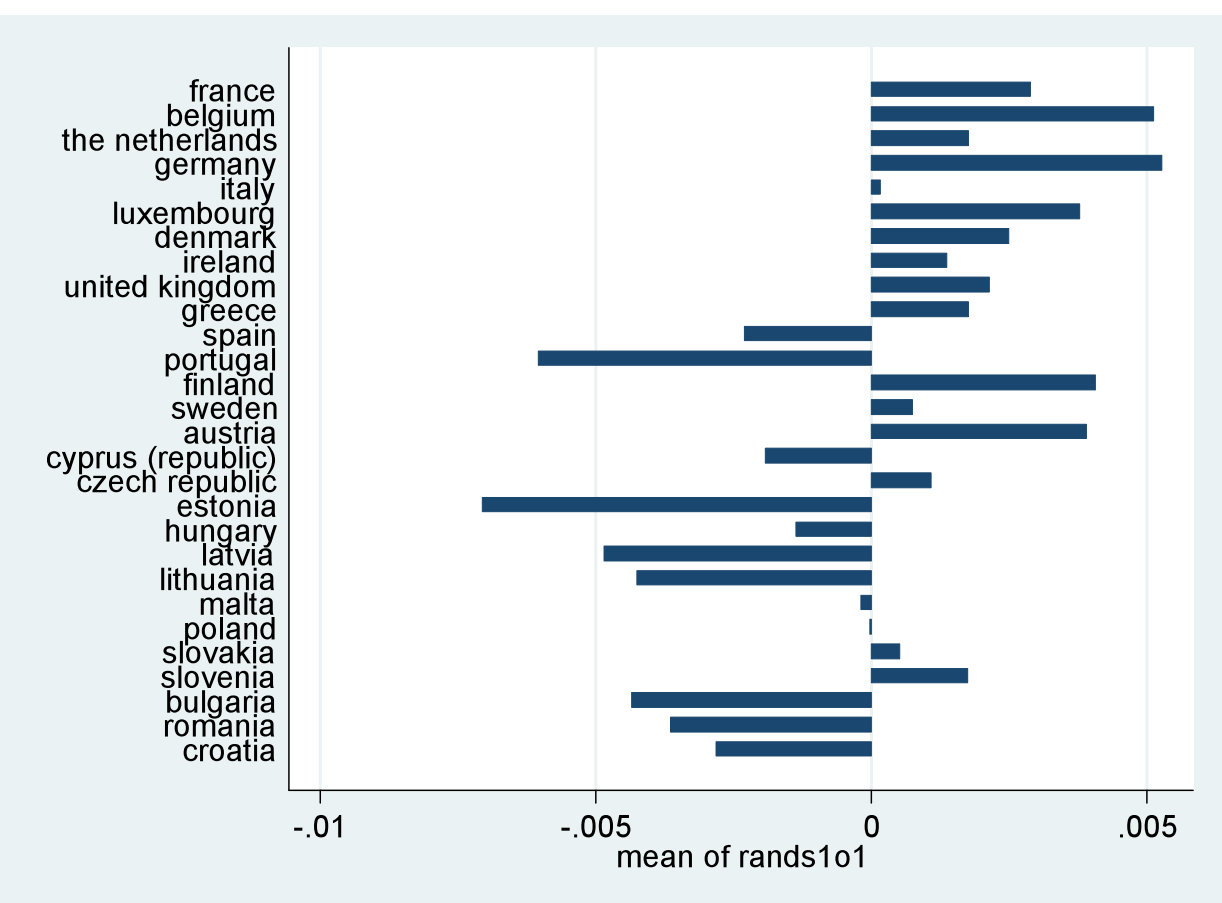




\section{b. Intercountry variations in the slope of Cage2}

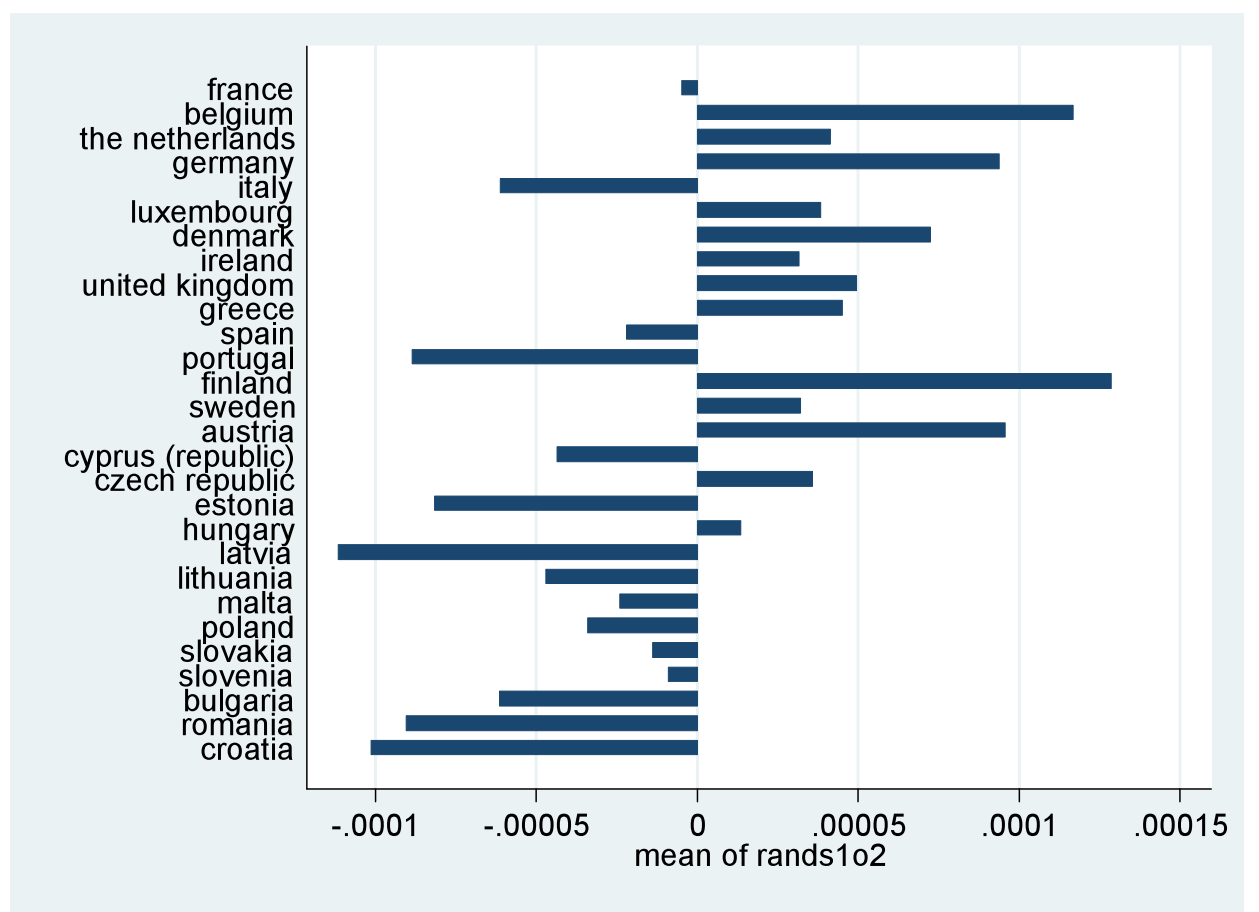

To illustrate, I have produced median splines of the predicted probabilities from the Cage and Cage 2 model of awareness for Germany where both up and down slopes are steeper than the European average, and Portugal where they are both lower. Note in both cases that the comparisons are with the European average. The estimated model for Germany is

(5.2) Aware $_{\text {Germany }}=2.62+0.0066$ Cage -0.00022 Cage $^{2}$
$5.45 \quad-3.43$

For Portugal the model is

$\begin{array}{cc}\text { (5.3) } \text { Aware }_{\text {Portugal }}=2.58-0.007 \text { Cage } & -0.00032 \text { Cage }^{2} \\ -4.61 & -3 . .97\end{array}$

Note that the sign on the Cage variable for Portugal is negative. The difference between the two equations and that estimated for Europe as a whole is reflected in the following plot. 
Figure 5.6 Predicted levels of awareness by age in Germany and Portugal compared to the European average, 2009

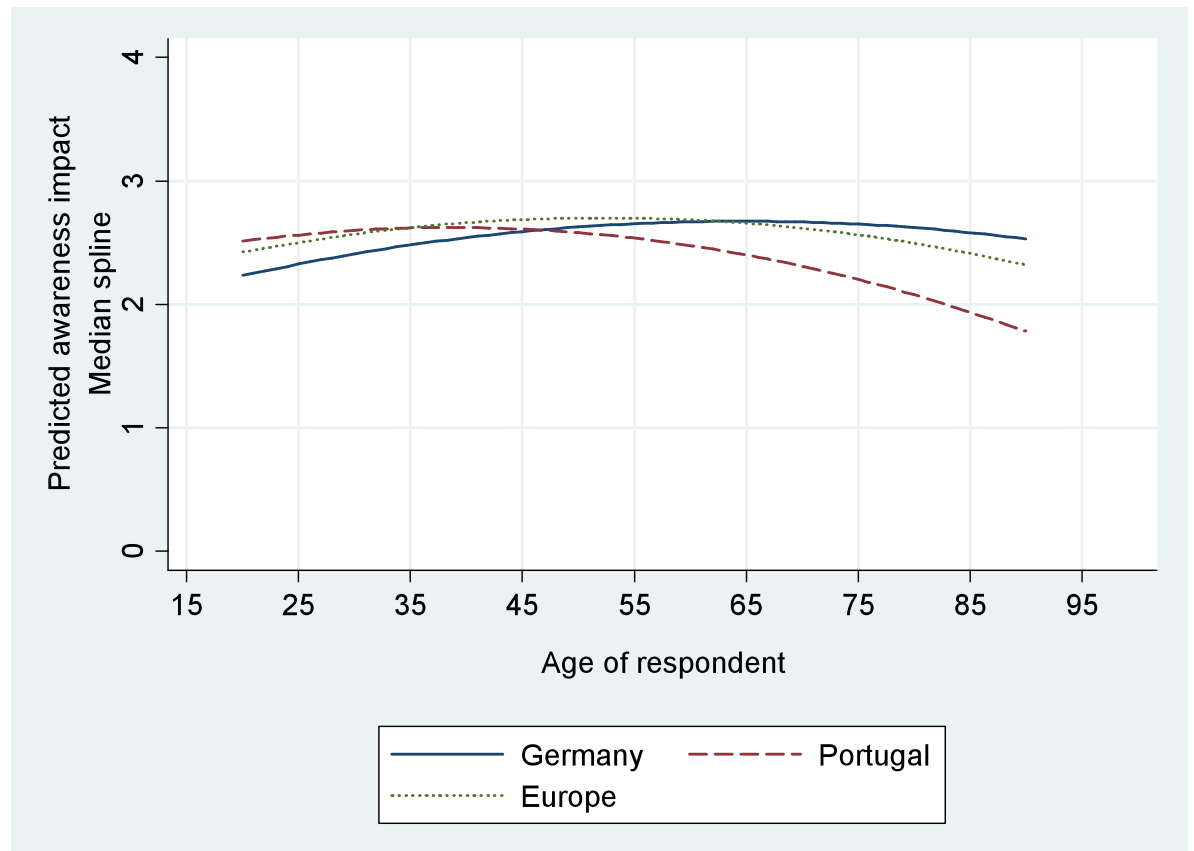

Source: Eurobarometer, 2009

Among German respondents awareness is clearly lowest among the youth but rises, at a decreasing rate with age, reaching its maximum at 66.6 years. Among respondents living in Portugal however predicted levels of awareness reach a maximum at almost half that age, 38.5 years and decline thereafter, at an accelerating rate. Both results are consistent with the two figures present prior to this one. Germany's 'up' slope is greater than the European average as is its down slope. The reverse is the case for Portugal, its 'up' slope is less and so is its 'down' slope. Portugal exhibits negative deviations from the average in both slopes. The gap between young and old in their awareness is less but awareness falls more rapidly with age.

With this illustration in mind I return to the multilevel model and predicted random slopes for Cage and Cage2. Since these represent deviations from the European wide average plotting them against each other is a way of summarizing the overall pattern of deviations country's exhibit from the European average. Figure 5.7 plots the deviation of the random coefficient 'up' slope for each country against the deviation of the random 'down' slope, in other words the random slope coefficients on Cage 
and Cage2.

Figure 5.7: The best linear predictions of deviations of countries from the European average with respect to the effect of age on awareness of purchased product impacts. Europe 2009

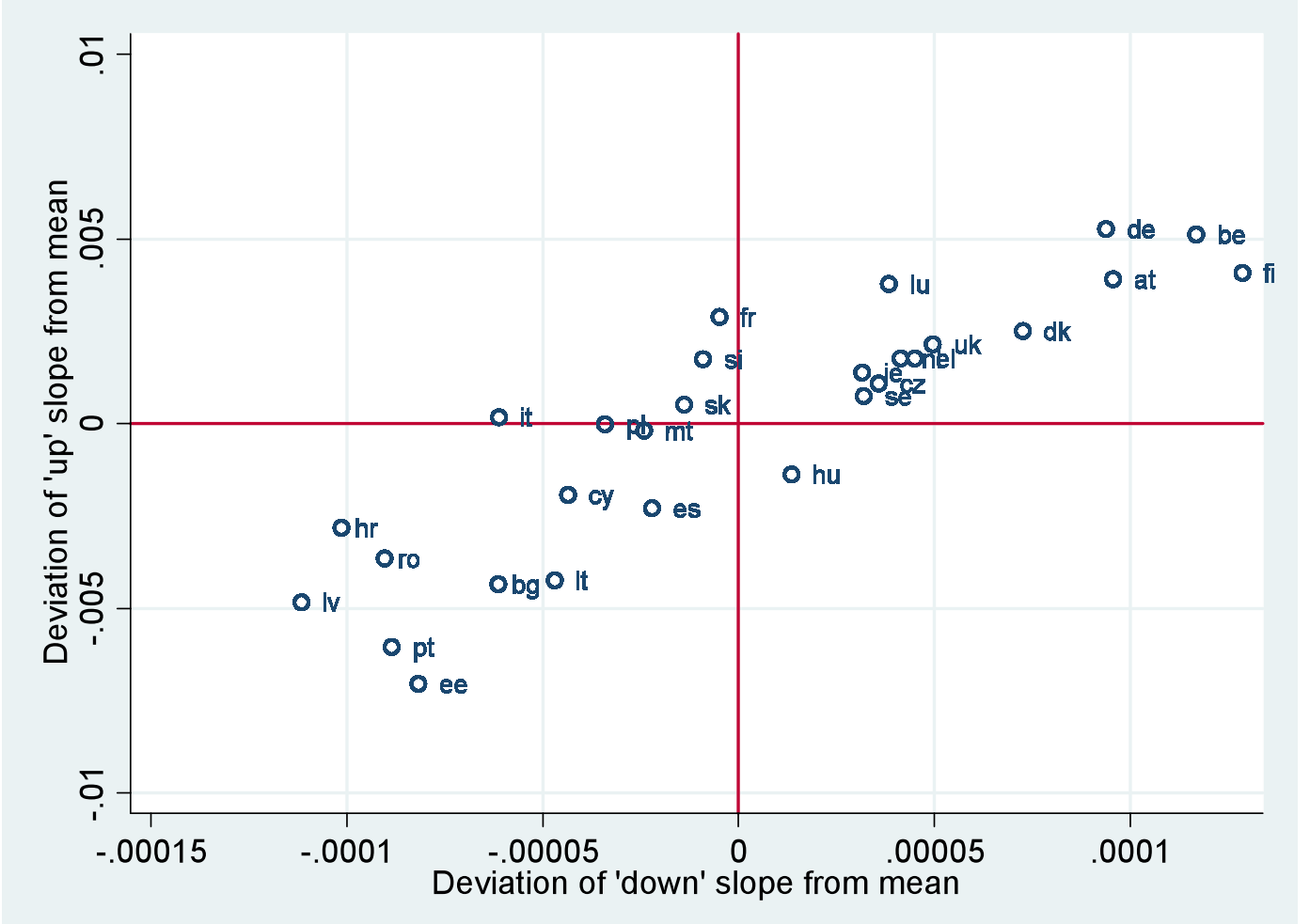

Source: Eurobarometer, 2009

Note: France (fr), Belgium (be), The Netherlands (nl), Germany (de), Italy (it), Luxembourg (lu), Denmark (dk), Ireland (ie), United Kingdom (uk), Greece (el), Spain (es), Portugal (pt), Finland (fi), Sweden (se), Austria (at), Cyprus (cy), Czech republic (cz), Estonia (ee), Hungary (hu), Latvia (lv), Lithuania, (lt), Malta (mt), Slovakia (sk), Slovenia (si), Bulgaria (bg), Romania (ro), Croatia (hr).

As my plot of the contrasting cases of Germany and Portugal showed, we would expect Germany to be located at the top right of this plot and Portugal at the bottom left. In this same say the relative slopes and hence the relative shape of the relationship of awareness to age can be compared across the remaining countries. One further illustration might help, this time for Finland (top right) compared to Lithuania (bottom left). 
Figure 5.8 Predicted levels of awareness by age in Finland and Lithuania compared to the European average, 2009

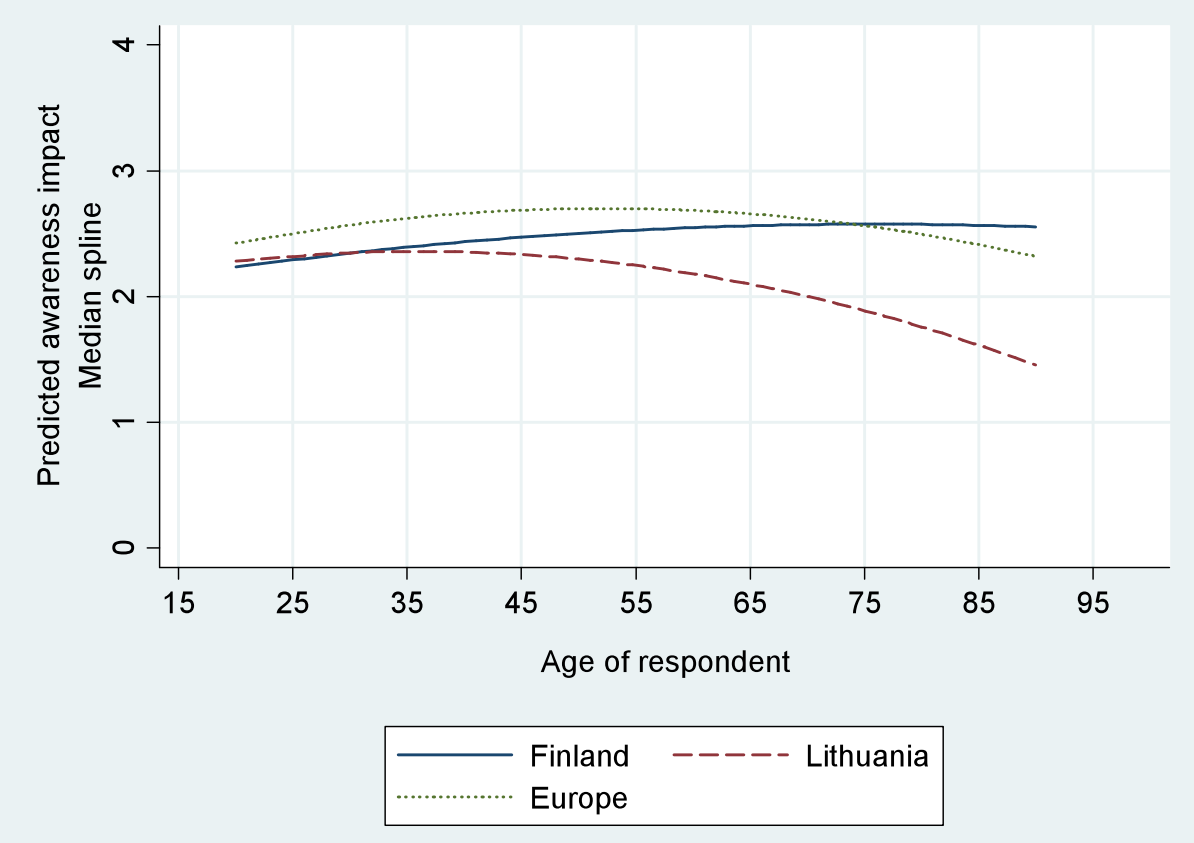

Source: Eurobarometer, 2009

As the relative positions of Finland and Lithuania in Figure 5.7, Figure 5.8, shows how Finland has a steeper 'up' slope than the European average (the difference is positive) and Lithuania, a shallower slope than the average (the difference is negative). And, when it comes to the down slope, the difference between awareness in middle and older ages, Finland shows a shallower (more positive) slope than Europe as a whole, and Lithuania a steeper negative slope. Therefore, like Germany and Portugal, they sit at either poles of the scatter in Figure 5.7 above.

The scatter of Figure 5.7 generated from the predicted random slopes from the multilevel model represents a succinct way of comparing the countries of Europe with respect to the way their level of awareness changes with age. What the scatter shows is that the variation lies primarily in the magnitude of the slopes rather than any difference in the signs. In other words, in almost all countries of Europe the middle age exhibit higher levels of awareness. The difference lies not in how much but rather in the tilt of the convex relationship between awareness in age. In the Germany vs. Portugal case, the German curve looks like the European curve rotated anticlockwise, where as the Portugal example shows the reverse; it exhibits a clockwise rotation. 
An inspection of the location of the countries in the scatter suggests that it is the more developed, higher income economies of Europe whose curves move anticlockwise; awareness rises more steeply from youth to middle age (than the European average) but more slowly from middle age to the old. By comparison, many of the former Eastern block countries and those with lower average incomes (and younger populations) exhibit a clockwise tilt to their convex curves. Youth exhibit greater awareness and there is less of a climb to the middle age but there is a steeper descent in awareness from middle age to their older populations.

How much these conclusions would be modified if the multilevel model also controlled for education and occupation has not been investigated. However I showed earlier that the quadratic model lay relatively undisturbed by these controls where they were entered into the European wide model and I doubt if this result would be overturned in specific country cases.

With these results in place, it is instructive to turn to the way peoples concerns over the importance of product impacts vary by country relative to European average.

\subsection{A multilevel model of environmental concern}

The same exercise can be carried out to explore the impact different age groups attach to the importance of the impact products have on the environment. Chapter 4 showed how average levels of concern for the environment in Europe, although also rising with age, did not exhibit the same decline after middle age. The degree to which this relationship varies by age across the 28 countries is also of interest. With the preliminaries covered in the previous case we can jump to the main model, as shown in table 5.10.

The results can be summarised in the same way, in a scatter of the random intercepts of Cage and Cage2, Figure 5.9. There is a similar distribution of countries - with Germany at one end and Portugal at the other. However in the case of concern over product impacts there is not only not the strong downward shift from middle to older age in the European wide equation but there is considerably less variation around that average when it comes to the steepness of that slope. The main variation in the 
impact of product case is around how steeply concerns rise from youth to middle age in the southern European countries of Portugal and Italy along with Romania.

Table 5.10: Estimates of age and country effects in the multilevel model of concern for the impact of products on the environment. Europe, 2009

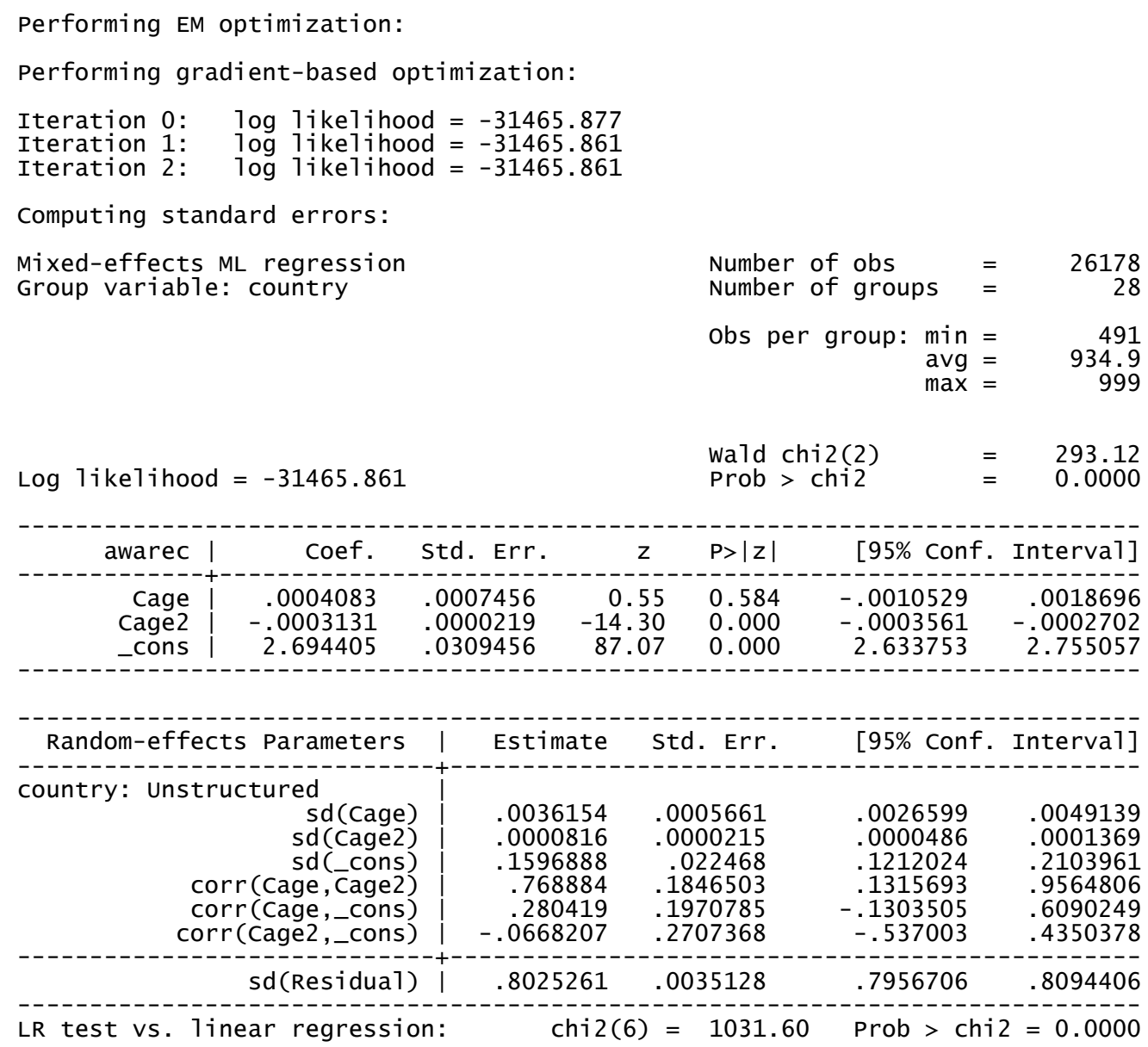

Source: Eurobarometer, 2009 
Figure 5.9 The best linear predictions of deviations of countries from the European average with respect to the effect of age on concern over the environmental impact of purchased product impacts. Europe 2009

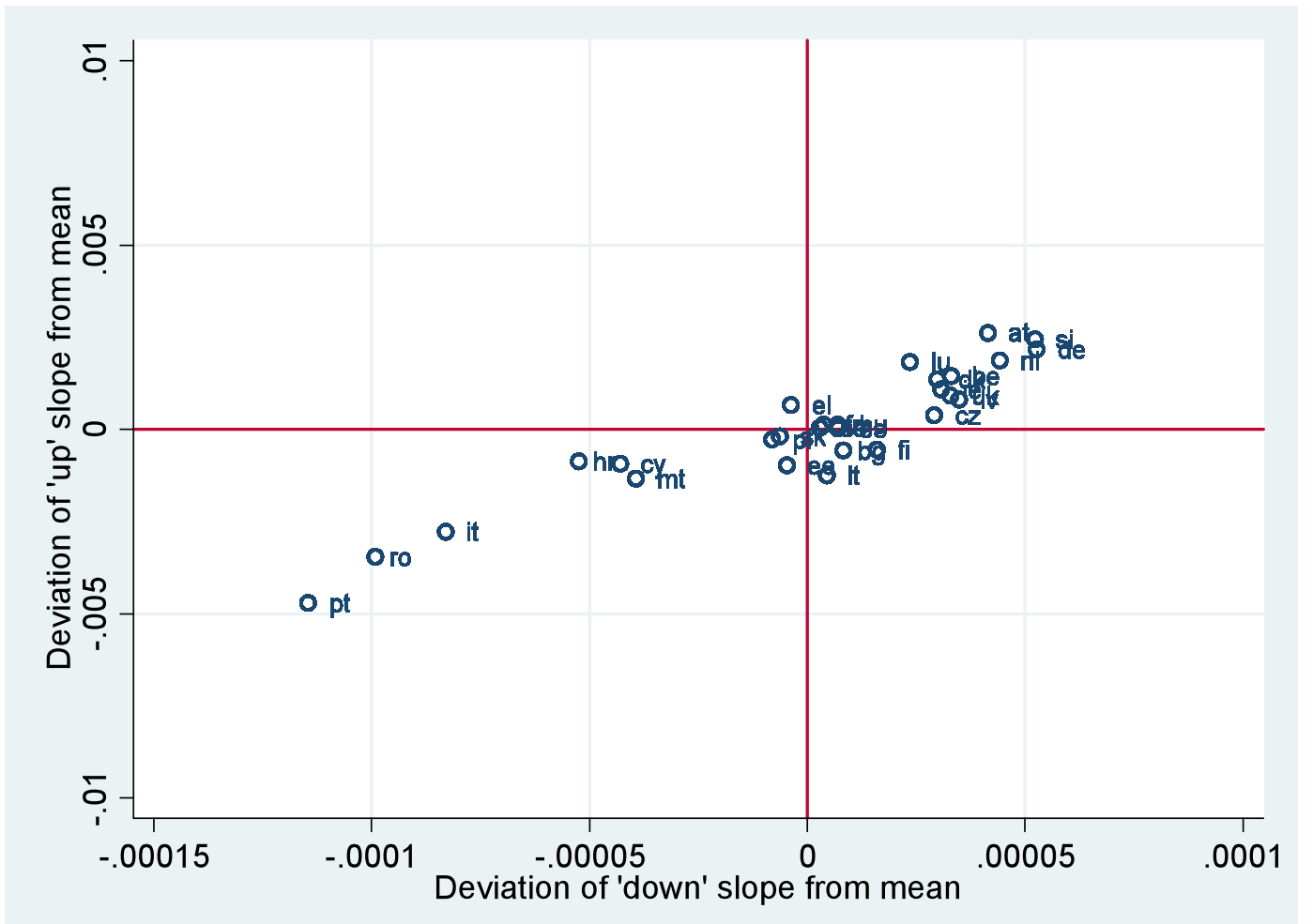

Source: Eurobarometer, 2009

\subsection{Summary}

In summary, what this chapter has shown is firstly that both awareness of environmental impacts of products and concerns over their importance do vary with age. Awareness and concern both rise with age to the point where middle aged consumers appear more sensitive to environmental impacts than the young. This holds whether or not one controls for gender, education, employment and settlement type. These controls are instructive in their own right of course and my results are largely consistent with what the literature has found. Where my results do differ however, and go further than the existing literature, is when it comes to the influence of age in both Europe as a whole and the way this relationship varies across the countries of Europe. 
The results for Europe as a whole were instructive because they show that certainly the difference between young and middle aged consumers carries over into reactions to policy initiatives such as labelling products to increase environmental awareness. At the same time, I have been able to show that the European result does not hold uniformly across all the 28 countries. Using multilevel modelling I have explicitly identified context effects, the effect of living in one country as opposed to another, and shown that their incorporation into both models increased my ability to account for the variance in responses to the two survey questions.

Furthermore I have shown firstly that the size of the country and its income are positively associated with awareness and concern over impact and that higher levels of environmental pollution as measured by $\mathrm{CO} 2$ emission levels are negatively correlated with awareness. Each of these results has support in the literature although researchers are not always uniform in their conclusions.

The other way I have sought to identify patterns in the rates at which awareness and concern change with age across Europe is by exploring country differences in the levels of concern but particularly in their slopes. Using predicted random slopes from the multilevel equation I was able to show how countries varied systematically in the way awareness changes with age. The inverse $U$ or boomerang shape tilts according to the country involved. I demonstrated this variation by comparing how each countries orientation differed from the European average. So in the example provided Germany's curve was tilted anticlockwise compared to the European average indicating that along with other higher income countries in Europe awareness rose steeply from a lower level of youth awareness, but after peaking in an older middle age descended less steeply into older age. Portugal represented another class of younger lower income country in which there was less of a gap in awareness between young and a younger middle age group but a steeper descent through to the older population. I told a similar story in comparing Finland with Lithuania.

The differences between countries were similar when it came to the way concern for the impact of purchased products on the environment changed with age. The clustering of the countries with respect to the empirical shape of this relationship was similar but with less variation in part because concern for the importance of effect 
showed considerably less decline into older age than was apparent in the awareness case. 


\section{Conclusion}

Global consumption has placed a great deal of pressure on the environment and there is an increasingly important need to improve the sustainability levels of consumption throughout the world. The continued availability of green products is a step in the right direction, however to aid green product manufacturers it helps if we can determine the characteristics of those who predominantly buy green products.

Because of the conflicting conclusions of previous research, the demography of the green consumer remains to be illusive. The literature reveals the lack of clear consensus here, especially in relation to age - some argue that younger persons fit the profile of the green consumer, while others fail to find such evidence. Relatively few consider the possibility that age may be non-linear in its effect. Therefore, I conducted this research with the aim of understanding how increased age affects environmental consciousness and did this with the expectation of finding a non-linear relationship. My survey data allowed me to examine how the influence of age on environmental consciousness changes across countries in the EU27 and Croatia.

My analysis revealed three important outcomes. Firstly (and most central to the thesis) is the discovery of 'mid-life greenness' - the way that environmental consciousness is lowest among the young, peaks at middle age and declines into old age which is demonstrated in an inverse $U$ shape relationship. It does so not only for European citizens' awareness and concern of the environmental impact of products, but the same is true for various policy initiatives aimed at making European consumption more environmentally safe. My findings support the conclusions Finisterra do Paço and Raposo, (2010); Abeliotis et al. (2010) and Bantye et al. (2010) who found it is the middle age segments most inclined towards pro-environmental consciousness, and contradict previous research which finds younger consumers to be more environmentally conscious (e.g., Anderson and Cunningham, 1972; Tognacci et al. 1972; Van Liere and Dunlap 1980; Zimmer et al 1994; Diamantopoulos et al. 2003; Jain and Kaur, 2008)

The second important finding from my research is that is that the effect of age on both 
awareness and concern of the environmental impact of products is not altered to any significant degree by considering positive effects of education, employment or settlement type. Or in other words, adding various control variables to the regression analysis does not markedly change the inverse $U$ shape slope as is demonstrated in Figures 4.8-10 in chapter 4. Thus there appears to be empirical support for my thesis that environmental consciousness peaks in middle age.

Based on the literature, I put forward three theories which might influence the relationship between age and environmental consciousness and explain the variance across different aged respondents in Europe - a cohort effect, life-cycle effect and situational characteristics such as region or country. Which of these three factors has the strongest influence cannot be formally tested using the cross sectional data I have at hand, however, the most substantial evidence suggests the stronger influences are a life-cycle effect and characteristics of the country a respondent lives in. Beginning with the life-cycle effect, the negative influence of being young on environmental awareness was not simply a matter of being young per se, but it is in youth in which certain characteristics are exhibited - being a student or a job seeker or raising young children - which are associated with lower levels of environmental awareness of product impact at this stage in life as my analysis reveals.

As was pointed out by Schultz and Zelezny (1999), the quantity of research into environmental consciousness using cross-country analysis is somewhat lacking. I was able to use the 28 country analysis of the 2009 Eurobarometer survey to go further than the existing literature when it comes to the influence of age in both Europe as a whole and the way this relationship varies across the countries of Europe. This leads me to my third key finding; despite the marked differences in countries across Europe, there is a significant degree of conformity to the convex age effect across all the 28 countries on environmental consciousness. However, at the same time there are clear country effects. Those people who are grouped into certain countries do exhibit both different levels of awareness and differences in the speed with which environmental consciousness rises and declines with age. For example, whilst the example of Portugal shows that awareness of environmental impact of products peaks in youth and declines steadily, the German example showed that the positive influence of age rose steeply from a lower level of youth awareness, but after peaking 
in an older middle age descended less steeply into older age.

In addition to the above the multilevel regression results also show that characteristics of countries such as population size, GDP and unemployment do have measurable effects on the way environmental consciousness varies with age. Specifically, my analysis has shown that the size of the country and its income are positively associated with awareness and concern over impact and that higher levels of environmental pollution as measured by $\mathrm{CO}^{2}$ emission levels are negatively correlated with awareness. These results support in the findings of Franzen and Meyer, (2003) and Inglehart (1995). The above findings demonstrate how the theory that situational characteristics such as the size, wealth and pollution levels of living in a certain country may influence environmental consciousness at certain stages of life. This supports arguments by Diamantopoulos et al. (2003), and Pinto et al. (2011).

\subsection{Extensions}

Whilst my report has made some important findings there are several ways in which this research could be extended. Firstly, it would be worthwhile to conduct a more extensive review of the literature to see whether similar studies to the 2009 Eurobarometer survey were conducted in earlier decades in Europe and then draw comparisons between them specifically in relation to the effect age has on environmental consciousness. This might help establish how strong any cohort effect might be on my results. Only two studies in my literature review (Balderjahn, 1988; Schahn and Holzer, 1990 - both in Germany) were conducted in Europe prior to the early 1990s. Surely there must be more - perhaps not published in English (Diamantopoulos et al. 2003) which is why I might not have discovered them in my review.

Secondly, it may be useful to conduct a similar survey to the 2009 Eurobarometer in New Zealand and Australia to ascertain the degree that age effects environmental consciousness closer to home. ${ }^{19}$ Although comparing two countries would be quite

\footnotetext{
${ }^{19}$ One study was conducted by Kilbourne and Polonsky, 2005 in New Zealand and Australia but only surveyed students and did not address the issue of sustainable consumption specifically.
} 
modest compared with the 28 country comparison undertaken by The Gallup Organisation (2009), a closer analysis could be conducted with respect to how environmental consciousness varies between geographic regions within countries. My analysis of population density (using the 'residence' variable) in the Eurobarometer survey revealed disappointing results - environmental consciousness did not influence the age effect to any statistically significant degree in either metropolitan or rural locations.

Whilst my analysis highlights the peak in 'green thinking' in the middle age years in Europe in 2009, does the same trend hold for Australasian consumers? It would be interesting to compare the results of such a study with my own. As the trend of global research into the profile of the green consumer continues, my thesis serves to highlight the importance of understanding how consumer consciousness differs at differing life stages across different countries.

In addition to further research in Australasia there is a lot of opportunity to do comparisons in many other geographic regions as well. As global environmental issues become more prominent in societies across the world today, an increased level of international research in this area of research will be of great benefit. 


\section{References}

Abeliotis, K. Koniari, C. and Sardianou, E. (2010) The Profile of the Green Consumer in Greece. International Journal of Consumer Studies, 34, 153-160.

Ahuvia, A. and Wong, N. (1995) Materialism: Origins and Implications for Personal Well-Being. Published in the proceedings of the 1995 European Conference for the Association for Consumer Research. Copenhagen, June 14-17, p. 1-22

Alibeli, N. and Johnson, C. (2009) Environmental Concern: A cross national analysis. Journal of International and Cross-cultural Studies, 3 (1), 1-10.

Anderson, W.T., Jr. and Cunningham, W.H.C. (1972) The socially conscious consumer. Journal of Marketing, 36(3), 23-31.

Arcury, T. A. and Christianson, E. H. (1990) Environmental worldview in response to environmental problems: Kentucky 1984 and 1988 compared. Environment Behavior, $22,387-407$.

Autio, M. Heiskanen, E. and Heinonen, V. (2009) Narratives of 'Green' ConsumersThe Antihero, the Environmental Hero and the Anarchist. Journal of Consumer Behaviour, 8 (1), 40-53.

Autio, M. and Heinonen, V. (2004) To Consume or Not to Consume? Young people's environmentalism in the affluent Finnish society. Young, 12 (3), 137-153.

Aydin, F. and Çepni, O. (2010) University students' attitudes towards environmental problems: A case study from Turkey, International Journal of the Physical Sciences, 5 (17), 2715-2720.

Balderjahn, I. (1988). Personality variables and environmental attitudes as predictors of ecologically responsible consumption patterns. Journal of Business Research, 17, $51-56$.

Banyte, J. Brazioniene, L. and Gadeikirene, A. (2010) Investigation of Green Consumer Profile: a Case of Lithuanian Market of Eco-friendly Food Products. Economics and Management, 15, 374-383.

Berenguer, J. Corraliza, J. and Martin, R. (2005) Rural-Urban Differences In Environmental Concern, Attitudes and Actions. European Journal of Psychological Assessment, 21(2), 128-138.

Berger, I.E. (1997) The Demographics of Recycling and the Structure of Environmental Behavior. Environment and Behavior, 29 (4), 515-531.

Berkowitz, L. and Lutterman, K.G. (1968) The traditional socially responsible personality. Public Opinion Quarterly, 32, 169-85.

Bickel R, 2007 Multilevel analysis for applied research. Its just regression! (The Guilford Press, London) 
Bodur, M. and Sarigollu, E. (2005) Environmental sensitivity in a developing country: consumer classification and implications. Environmental Behaviour, 37, (4) 487-510.

Brécard, D. Hlaimi, B. Lucas, S. Perraudeau, Y. and Salladarré, F. (2009) Determinants of demand for green products: An application to eco-label demand for fish in Europe. Ecological Economics, 69, 115-125.

Brécard, D. Hlaimi, B. Lucas, S. Perraudeau, Y. and Salladarré, F. (2009) Determinants of demand for green products: An application to eco-label demand for fish in Europe. Ecological Economics, 69, 115-125.

Burroughs, J. and Rindfleisch, A. (2002) Materialism and Well-Being: A Conflicting Values Perspective. The Journal of Consumer Research, 29, (3), 348-370.

Büttner, T. and Grübler, A. (1995) The birth of a "green generation"? Generational dynamics of resource consumption patterns. Technological Forecasting and Social Change, 50, 113-134.

Carlisle, S. and Hanlon, P. (2007) Well-being and consumer culture: a different kind of public health problem? Health Promotion International, 22 (3), 261-268.

Carrigan, M. and Attalla, A. (2001) The myth of the ethical consumer - do ethics matter in purchase behaviour? Journal of Consumer Marketing. 18 (7), 560-577.

Casey, P. and Scott, K. (2006) Environmental concern and behaviour in an Australian sample within an ecocentric-anthropocentric framework. Australian Journal of Psychology, 58 (2), 57-67.

Chan, K. (2000) Market Segmentation of Green Consumers in Hong Kong. Journal of International Consumer Marketing, 12 (2), 7-24.

Connolly, J. and Prothero, A. (2003) Sustainable Consumption: Consumption, Consumers and the Commodity Discourse. Consumption, Markets and Culture, 6 (4), 275-291.

Datta, S. (2011) Pro-environmental Concern Influencing Green Buying: A Study on Indian Consumers. International Journal of Business and Management, 6 (6), 124133.

Diamantopoulos, A. Schlegelmilch, B. Sinkovics, R. and Bohlen, G. (2003) Can socio-demographics still play a role in profiling green consumers? A review of the evidence and an empirical investigation. Journal of Business Research, 56, 465-480. 
Diez-Roux, A. (1998) Bringing context back into epidemiology: variables and fallacies in multilevel analysis. American Journal of Public Health, 88, 216-222.

Dunlap, R. and Mertig, A. (1995) Global Concern for the Environment: Is Affluence a Prerequisite? Journal of Social Issues, 51, 121-137.

Dunlap, R. and Mertig, A. (1997) Global Environmental Concern: An Anomaly for Postmaterialism. Social Science Quarterly, 78, 24-29.

Dychtwald, K. and Gable, G. (1990) Portrait of a Changing Consumer. Business Horizons, 33 (1), 62-73.

European Environment Agency, (2010) The European environment. State and outlook 2010. Consumption and the environment - SOER 2010 thematic assessment Copenhagen, EEA: 68.

European Environment Agency, (2011) Material Resources and Waste - key fact [online]. Available from http://www.eea.europa.eu/soer/europe/material-resourcesand-waste/key-facts/material-resources-and-waste-fact-1 [accessed on the 7th February 2012].

Eurostat (2011a) Sustainable Development in the European Union: 2011 monitoring report of the EU sustainable development strategy, Luxembourg: Office for Official Publications of the European Communities.

Eurostat (2011b) Population structure and ageing. Available from http://epp.eurostat.ec.europa.eu/statistics_explained/index.php/Population_structure_a nd_ageing\#Further_Eurostat_information [accessed on the $28^{\text {th }}$ February 2012 ]

Eurostat (2010) Environmental statistics and accounts in Europe. Office for Official Publications of the European Communities.

Ferrer-i-Carbonell, A. and Frijters, P. (2004) How important is methodology for the estimates of the determinants of happiness? The Economic Journal, 114, 641-659

Finisterra do Paco, A. and Raposo, M. (2008) Determining the characteristics to profile the "green" consumer: an exploratory approach. International Journal of Business Performance Managemen, 12 (1), 86 - 101.

Finisterra do Paco, A. and Raposo, M. (2010) Green consumer market segmentation: empirical findings from Portugal. International Journal of Consumer Studies, 34, $429-436$

Fotopoulos, C. and Krystallis, A. (2002), Purchasing motives and profile of the Greek organic consumer: a countrywide survey. British Food Journal. 104 (9), 730-765.

Franzen, A. and Meyer, R. (2009) Environmental Attitudes in Cross-national Perspective: A Multilevel Analysis of the ISSP 1993 and 2000. European Sociological Review, 26 (2), 219-234 
Freymeyer, R. and Johnson, B. (2010) A cross cultural investigation of factors influencing environmental actions. Sociological Spectrum: Mid-South Sociological Association, 30 (2), 184-195.

Furman, A. (1998) A Note on Environmental Concern in a Developing Country: Results From an Istanbul Survey. Environment and Behavior, 30 (4), 520-534.

Gatersleben, B. Steg, L. and Vlek, C. (2002) The measurement and determinants of environmentally significant consumer behaviour. Environment and Behaviour, 34 (3), 335-362.

Gilg, S. Barr, N. Ford, N. (2005) Green consumption or sustainable lifestyles? Identifying the sustainable consumer. Futures, 37, 481-504.

Gupta, S. and Ogden, D. (2009) To buy or not to buy? A social dilemma perspective on green buying. Journal of Consumer Marketing, 26 (6), 376-391.

Haanpää, L. (2007) Consumers' green commitment: indication of a postmodern lifestyle? International Journal of Consumer Studies, 31 (5), 478-486.

Hamilton, L. (2009) Statistics with STATA. Updated for version 10 Brooks/Cole: Belmont CA

Haron, S, Paim, L. and Yahya, N. (2005) Towards sustainable consumption: an examination of environmental knowledge among Malaysians. International Journal of Consumer Studies, 29 (5), 426-436.

Hume, M. (2010) Compassion without action: Examining the young consumers consumption and attitude to sustainable consumption. Journal of World Business, 45, 385-394.

Hunter , L. Hatch, A. and Johnson, A. (2004) Cross-national Gender Variation in Environmental Behaviors. Social Science Quarterly, 85, 677 - 694.

Inglehart, R. (1995) Public Support for Environmental Protection: Objective Problems and Subjective Values in 43 Societies. Political Science and Politics, 28 (1), 57-72.

Jain, S.K. and Kaur, G. (2004) Green marketing: An Attitudinal and Behavioural Analysis of Indian Consumers. Global Business Review, 5 (2), 187-205.

Jain, S.K. and Kaur, G. (2008) Role of Socio-Demographics in Segmenting and Profiling Green Consumers. Journal of International Consumer Marketing. 18 (3), 107-146.

Jackson, T. (2005) Live Better by Consuming Less? Is There a "Double Dividend" in Sustainable Consumption? Journal of Industrial Ecology, 9 (1-2), 19-36.

Jones, R. E. and Dunlap, R. E. (1992) The social bases of environmental concern: Have there been any changes? Rural Sociology, 57 (1), 28-47. 
Kilbourne, W. Beckmann, S. and Thelen, E. (2002) The Role of the Dominant Social Paradigm in Environmental Attitudes: A Multinational Examination, Journal of Business Research 55: 193-204.

Kilbourne, W. and Beckmann, S. (1998) Review and Critical Assessment of Research on Marketing and the Environment. Journal of Marketing Management, 14, 513-532.

Kilbourne, W. and Polonsky, M. (2005) Environmental Attitudes and their Relation to the Dominant Social Paradigm Among University Students In New Zealand and Australia. Australasian Marketing Journal 13 (2), 37-48

Kinnear, T. Taylor, J. Ahmed, S. (1974) Ecologically Concerned Consumers: Who are They? The Journal of Marketing. 38 (2), 20-24.

Laroche, M. Bergeron, J. Barbaro-Forleo, G. (2001) Targeting consumers who are willing to pay more for environmentally friendly products. Journal of Consumer Marketing, 18, 503-520.

Lee, K. (2009) Opportunities for green marketing: young consumers. Marketing Intelligence and Planning, 26 (6), 573-586.

Mainieri, T. Barnett, E. Valdero, T. Unipan, J. and Oskamp, S. (1997) Green buying: The influence of environmental concern on consumer behavior. The Journal of Social Psychology, 137 (2), 189-204.

Marquart-Pyatt, S (2007) Concern for the Environment Among General Publics: A Cross-National Study. Society \& Natural Resources: An International Journal, 20 (10), 883-898.

Marquart-Pyatt, S (2008) Are There Similar Sources of Environmental Concern? Comparing Industrialized Countries. Social Science Quarterly, 89 (5), 1312-1334.

McDonald, S. Oates, C. Thyne, M. Alevizou, P. and McMorland, L. (2009) Comparing sustainable consumption patterns across product sectors.

International Journal of Consumer Studies, 33, 137-145.

Meffert H, Bruhn M. (1996) Das Umweltbewußtsein von Konsumenten. Die BeTriebswirtsch, 56(5), 621-48.

Milfont, T. and Duckitt, J. (2009) The environmental attitudes inventory: A valid and reliable measure to assess the structure of environmental attitudes. Journal of Environmental Psychology, 30, 80-94.

Mitchell, R. (2001) Multilevel modeling might not be the answer Environment and Planning A, 33, 1357-1360.

Mont, O. and Plepys, A. (2007) Sustainable consumption progress: should we be proud or alarmed? Journal of Cleaner Production, 16, 531-537. 
Mostafa, M. (2009) Shades of green: A psychographic segmentation of the green consumer in Kuwait using self-organizing maps, Expert Systems with Applications, 36, 11030-11038.

Murphy, P. Kangun, N. Locander, W. (1978) Environmentally Concerned Consumers - Racial Variations. The Journal of Marketing. 42 (4), 61-66.

National Geographic. (2011) Greendex 2010: Consumer Choice and the Environment - A Worldwide Tracking Survey. [Online] Available from http://environment.nationalgeographic.com/environment/greendex/ [Accessed $11^{\text {th }}$ December, 2011]

Nevitte, N. and Kanji, M. (1995) Explaining Environmental Concern And Action in Cananda. Applied Behavioural Science Review, 3 (5), 85-102.

Peattie, K. (2001) Golden Goose or Wild Goose? The Hunt for the Green Consumer. Business Strategy and the Environment, 10, 187-199.

Peattie, K. and Peattie, S. (2009) Social marketing: A pathway to consumption reduction? Journal of Business Research. 62, 260-268.

Peattie, K. and Crane, A. (2005) Green marketing: legend, myth, farce or prophesy? Qualitative Market Research: An International Journal Volume, 8 (4), 359-369.

Pepper, M. Jackson, T. and Uzzell, D. (2009) An examination of the values that motivate socially conscious and frugal consumer behaviours. International Journal of Consumer Studies, 33, 126-136.

Pinto, D. Nique, W. Añaña, E. and Herter, M. (2011) Environmental concern and behaviour in an Australian sample within an ecocentric - anthropocentric framework. Australian Journal of Psychology, 58 (2), 57-67.

Pickett, K. and Perl, M. (2001) Multilevel analysis of neighbourhood socioeconomic context and health outcomes: a critical review Journal of Epidemiology and Community Health, 55 111-122.

Rabe-Hesketh, S. and Skrondal, A. (2008) Multilevel and longitudinal modeling using Stata (Stata Press, College Station, Texas).

Ramayah, T. Lee, J. and Mohamad, O. (2010) Green product purchase intention: Some insights from a developing country. Resources, Conservation and Recycling, 54 (12), 1419-1427.

Roberts JA. (1996a) Will the Real Socially Conscious Consumer Please Step Forward, Business Horizons, 39 (1), 79-83.

Roberts JA. (1996b) Green consumers in the 1990s: profile and implications for advertising. Journal Business Research, 36 (3), 217-31.

Robins, N. (1999) Making sustainability bite: Transforming global consumption 
patterns. The Journal of Sustainable Product Design. [Online] Available from: $\mathrm{http}: / /$ scholar.google.co.nz/scholar_url?hl=enandq=http://www.unep.fr/shared/publica tions/cdrom/WEBx0028xPA/contents/screading3.pdfandsa=Xandscisig=AAGBfm1T E0S7IAuZhy09Uia0psIVYSXTRgandoi=scholarr [Accessed $13^{\text {th }}$ December, 2011]

Roos, A. and Nryud, A. (2008) Description of green versus environmentally indifferent consumers of wood products in Scandinavia: flooring and decking. Journal of Wood Science, 54 (5), 402-407.

Samdahl, M. and Robertson, R. (1989) Social determinants of environmental concern: Specification and test of the model. Environment and Behavior, 21 (1), 57-81.

Saphores, J. Nixon, H. Ogunseitanc, O. Shapirod, A. (2007) California Households' Willingness to Pay for "Green" Electronics. Journal of Environmental Planning and Management, 50 (1), 113-133.

Sanne, C. (2002) Willing consumers--or locked-in? Policies for a sustainable consumption. Ecological Economics, 42, (1-2), 273-287.

Sanne, C. (2005) The Consumption of our Discontent. Business Strategy and the Environment, 14, 315-323.

Schaefer, A. and Crane, A. (2005) Addressing sustainability and consumption. Journal of Macromarketing, 25, 76-92.

Schahn, J. and Holzer, E. (1990) Studies of individual environmental concern: the role of knowledge, gender, and background variables. Environmental Behaviour, 22 (6), $767-786$.

Schewe, C. D. and Meredith, G. (2004) Segmenting global markets by generational cohorts: Determining motivations by age. Journal of Consumer Behavior, 4 (1), 5163.

Schlegelmilch, B. Bohlen, G. and Diamantopoulos, A. (1996). The link between green purchasing decisions and measures of environmental consciousness. European Journal of Marketing, 30 (5), 35-55.

Schor, J.B., 2005. Prices and quantities: Unsustainable consumption and the global economy. Ecological Economics. 55, pp. 309-320

Schultz, P. and Zelezny, L. (1999) Values as predictors of environmental attitudes: Evidence for consistency across 14 countries. Journal of Environmental Psychology, $19,255-265$.

Scott, D. Willits, K. (1994) Environmental attitudes and behavior: a Pennsylvania survey. Environment and Behaviour. 26 (2), 239-60.

Shen, J. and Saijo, T. (2008) Reexamining the relations between socio-demographic characteristics and individual environmental concern: Evidence from Shanghai data. Journal of Environmental Psychology, 28, 42-50. 
Shrum, L. McCarty, J. and Lowrey, T. (1995) Buyer characteristics of the green consumer and their implications for advertising strategy. Journal of Advertising. 24 (2), $71-82$.

Sinnappan, P. and Rahman, A. (2011) Antecedents of Green Purchasing Behavior among Malaysian Consumers. International Business Management, 5 (3), 129-139.

Skrentney, J. (1993) Concern for the Environment: A cross-national perspective. International Journal of Public Opinion Research. 5 (4), 335-352.

Soron, D. (2010) Sustainability, Self-Identity and the Sociology of Consumption. Sustainable Development. 18, 172-181.

Straughan, R. and Roberts, J. (1999) Environmental Segmentation Alternatives: a Look at Green Consumer Behavior in the New Millennium. Journal of Consumer Marketing, 16 (6), 531-575.

Stern, P. (2000) Toward a coherent theory of environmentally significant behavior. Journal of Social Issues, 56, 407-424.

Subramanian, S. Jones, K. and Duncan, C. (2003) Multilevel methods for public health research, in Neighbourhoods and health Eds I Kawachi, L F Berkan (Oxford University Press, Oxford) 65-111.

Tantawi, P. O'Shaughnessy, N. Gad, K. and Ragheb, M. (2009) Green Consciousness of Consumers in a Developing Country: A Study of Egyptian Consumers. Contemporary Management Research, 5 (1), 29-50.

The Gallup Organisation. (2009) Europeans' Attitudes Towards the Issue of Sustainable Consumption and Production. European Commission, Special Eurobarometer 256

Thompson, D. Anderson, R. Hansen, E. Kahle, L. (2010) Green Segmentation and Environmental Certification: Insights from Forest Products. Business Strategy and the Environment, 19, 319-334.

Tognacci, N. Weigel, R. Wideen, F. Vernon, D. (1972) Environmental Quality: How Universal is Public Concern? Environment and Behavior. 4 (1) 73-86.

Tremblay, K and Dunlap, R. (1977) Rural-Urban Residence and Concern with Environmental Quality - A Replication and Extension. Paper presented at the Annual Meeting of the Rural Sociological Society (Madison, Wisconsin, September 1977).

Van Liere, K. and Dunlap, R. (1980) Environmental concern: does it make a difference? How it is measured? Environment and Behaviour, 13 (6), 651-76.

Veenhoven, R. (2004) Sustainable consumption and happiness. MPRA Paper, University Library of Munich, Germany. 
Webster, E. (1975) Determining the Characteristics of the Socially Conscious Consumer, Journal of Consumer Research, 2, 188-196.

Weich, S. Twigg, L. Holt, G. Lewis, G. Jones, K. (2003) Contextual risk factors for the common mental disorders in Britain: a multilevel investigation of the effects of place. Journal of Epidemiol. Community Health, 57, 616-621.

Wells, V. Ponting, C. and Peattie, K. (2011) Behaviour and climate change : consumer perceptions of responsibility. Journal of marketing management, 27 (7-8), 808-833.

Wong, V. Turner, W. and Stoneman, P. (1996) Marketing Strategies and Market Prospects for Environmentally-Friendly Consumer Products, British Journal of Management, 7, 263-281.

Xiao, C. and Dunlap, R. (2007) Validating a comprehensive model of environmental concern cross-nationally: A Canadian-USA comparison. Social Science Quarterly, 88, 471-493.

Xiao, C. and McCright, A. (2007) Environmental concern and sociodemographic variables: a study of statistical models. Journal of Environmental Education, 38 (2), $3-14$.

Young, W. Hwang, K. McDonald, S. and Oates, C. (2009) Sustainable Consumption: Green Consumer Behaviour when Purchasing Products. Sustainable Development, 18 (1), 20-31.

Zarnikau, J. (2003) Consumer Demand for 'Green Power' and Energy Efficiency. Energy Policy, 31, 1661-1672

Zelezny, L. Chua, P. and Aldrich. C (2000) Elaborating on Gender Differences in Environmentalism. Journal of Social Issues, 56 (3), 443-457.

Zimmer, M. Stafford, T. and Stafford, M. (1994) Green issues: dimensions of environmental concern. Journal of Business Research, 30 (1) 63-74. 


\title{
Appendices
}

\author{
Appendix 1
}

List of questions used in the 2009 Eurobarometer Survey

\author{
FLASH - 256 \\ "SUSTAINABLE CONSUMPTION \& PRODUCTION"
}

Q1. In general, how much do you know about the environmental impact of the products you buy and use?

[READ OUT - ONLY ONE ANSWER POSSIBLE]

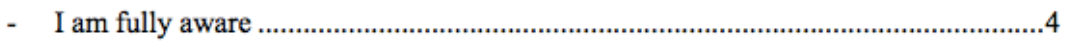

- I know about the most significant impacts .............................................................

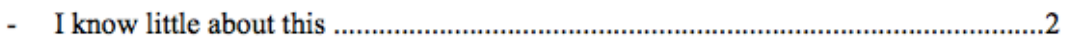

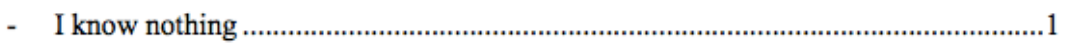

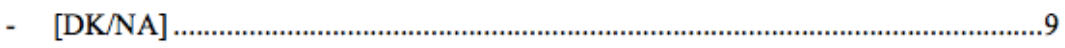

Q2. How important are the following aspects when making a decision on what products to buy? Very important, rather important, rather not important, not at all important?

[READ OUT - ONE ANSWER PER LINE]

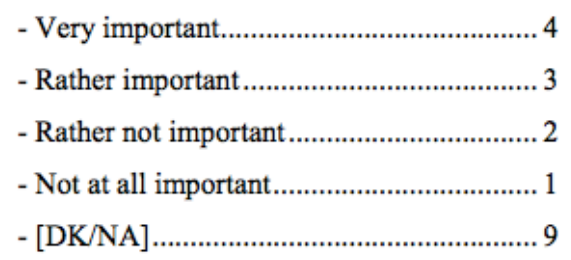

Q3. Some products have an ecolabel which certifies that they are environmentally-friendly. Which statement characterises you the best?

[READ OUT - ONLY ONE ANSWER POSSIBLE]

- Ecolabelling plays an important part in my purchasing decisions $\ldots 1$

- Ecolabelling does not play an important part in my purchasing decisions ................. 2

- I never read any labels ......................................................................................

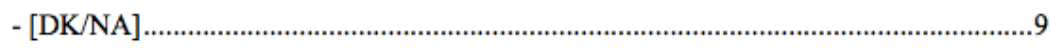


Q4. Environmental labels should be concise. From the list I am going to read you what environmental information is the most important that a label should contain?

[READ OUT - ROTATE - ONLY ONE ANSWER POSSIBLE]

- Confirmation that the product comes from environmentally-friendly sources ............1

- Confirmation that the packaging is eco-friendly ........................................................2

- The total amount of greenhouse gas emissions created by this product......................... 3

- Whether the product can be recycled / reused ............................................................

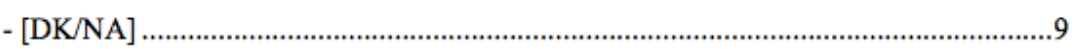

The total amount of greenhouse gas emissions produced directly and indirectly by the product is called the carbon footprint of a product. It measures the impact on the environment from its production, sale and use, and in particular climate change. (SHOULD BE READ BEFORE FOR Q5)

Q5. Should a label indicating the carbon footprint of a product be mandatory in the future?

[READ OUT - ONLY ONE ANSWER POSSIBLE]

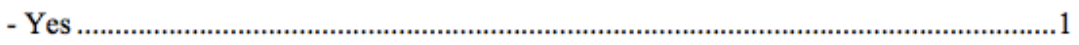

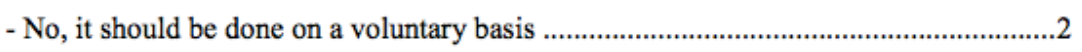

- The carbon footprint is of no interest to me .................................................................

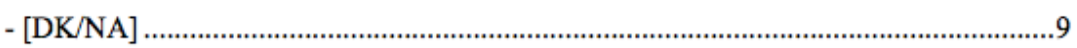

Q6. How can retailers best contribute to promoting environmentally-friendly products? [READ OUT - ROTATE - ONLY ONE ANSWER POSSIBLE]

- Provide better information to consumers .............................................................. 1

- Have regular promotions in their stores focusing on environmentally-friendly products 2

- Have a dedicated green corner within their stores with only environmentally-

friendly products ...................................................................................................... $\quad 3$

- Increase the visibility of environmentally-friendly products on shelves........................ 4

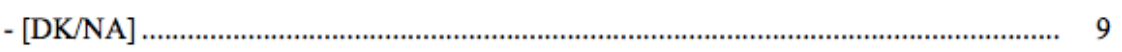

Q7. What type of taxation system should public authorities consider using in order to promote environmentally-friendly products?

[READ OUT - ONLY ONE ANSWER POSSIBLE]

- ... to reduce taxation for more environmentally-friendly products ..............................1

- .... to increase taxes for environmentally-damaging products......................................2

- ... a combination of both ....................................................................................

- [Introducing a taxation system to promote environmentally-friendly products

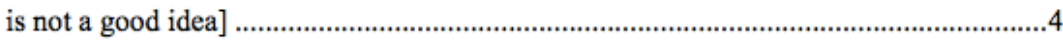

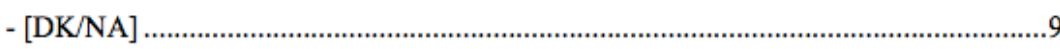


Q8. In your opinion, which one of the following actions would have the highest impact on solving environmental problems?

[Interviewer, if respondents ask: "Sustainable modes of transport" are means of transport that do not cause damage/do less damage to the environment (e.g. emit less greenhouse gas emissions, use of renewable resources etc.), and therefore promote sustainable development and contribute to the fight against climate change. Some real life examples are: taking the train instead of an airplane when travelling abroad, going to work by bicycle or public transport and not by car, or car sharing]

[READ OUT - ROTATE - ONLY ONE ANSWER POSSIBLE]

- Buying products produced by eco-friendly production..............................................

- Buying energy-efficient home appliances...............................................................2

- Making efforts to use less water.................................................................................

- Minimising waste and recycling ..........................................................................

- Travelling less and adopting sustainable modes of transport ........................................5

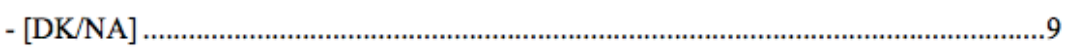

The EU Ecolabel (the Flower) is a certification scheme that helps European consumers distinguish greener, more environmentally-friendly products and services. (SHOULD BE READ BEFORE FOR Q9)

Q9. Are you aware of the Flower, the symbol of the EU Ecolabel?

[READ OUT - ONLY ONE ANSWER POSSIBLE]

- I've seen it or heard of it and I have bought products with this label . .1

- I've seen it or heard of it but I have not bought products with this label.......................2

- I have never seen it nor heard of it............................................................................

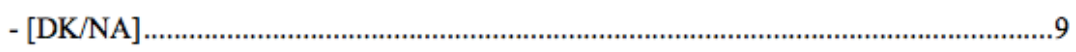

Q10. How much do you trust producers' claims about the environmental performance of their own products?

[INTERVIEWER: "the environmental performance of (...) a product" = how well (or badly) a product performs from an environmental point of view. That includes the ecological/carbon footprint of the product, the ecological-friendliness of the production, distribution/sale, use of the product and the possibility to reuse/recycle it.]

[READ OUT - ONLY ONE ANSWER POSSIBLE]

-Trust completely . .4

-Rather trust....................................................................................................

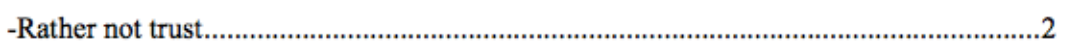

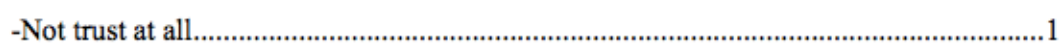

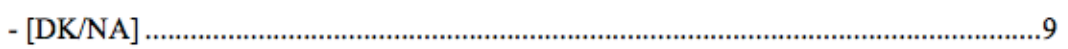


Q11. Which statement best reflects your view on cur rent reporting by companies on their own environmental and social performance:

[READ OUT - ONLY ONE ANSWER POSSIBLE]

- I trust the reporting of the companies' own environmental and social performance .......

- I do not trust the reporting of the companies' own environmental and social performance

- Companies' reporting on their environmental and social performance is of no interest to me 3

- [DK/NA]

Q12. When buying products that use electricity (like TVs or computers) or fuel (boilers, cars), do you take into account how energy efficient they are? An energy-efficient product is a product that can perform the same task as another by using less energy to do so.

[READ OUT - ONLY ONE ANSWER POSSIBLE]

-Most of the time, often

Q13. It has been proposed by the EU that retailers develop a voluntary environmental code of conduct. Which opinion is closer to your view?

[READ OUT - ONLY ONE ANSWER POSSIBLE]

- I think it is a good idea .3

- Retailers are already doing a lot for the environment and a voluntary code of conduct is not needed .2

- It is better to use binding legislation than a voluntary code of conduct .........................1

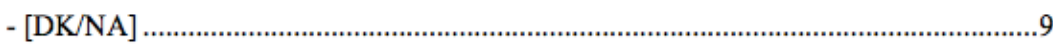

Source: Eurobarometer, 2009: p. 82-86 


\section{Appendix 2.}

\section{Sampling}

Surveys are designed and conducted to provide an estimate of a true value of characteristics of a population at a given time and as such are unlikely to exactly equal the true population quantity of interest for a variety of reasons. One of these reasons is that data in a survey are collected from only some - a sample of - members of the population, in order to make data collection cheaper and faster. The "margin of error" is a common summary of sampling error, which quantifies uncertainty about (or confidence in) a survey result.

Usually, one calculates a 95 percent confidence interval of the format: survey estimate $+/$ - margin of error. This interval of values will contain the true population value at least $95 \%$ of time. For example, if it was estimated that $45 \%$ of EU citizens are in favour of a single European currency and this estimate is based on a sample of 100 EU citizens, the associated margin of error is about 10 percentage points. The 95 percent confidence interval for support for a European single currency would be $(45 \%-10 \%)$ to $(45 \%+10 \%)$, suggesting that in the EU the support for a European single currency could range from $35 \%$ to $55 \%$. Because of the small sample size of $100 \mathrm{EU}$ citizens, there is considerable uncertainty about whether or not the citizens of the EU support a single currency.

As a general rule, the more interviews conducted (sample size), the smaller the margin of error. Larger samples are more likely to give results closer to the true population quantity and thus have smaller margins of error. For example, a sample of 500 will produce a margin of error of no more than about 4.5 percentage points, and a sample of 1,000 will produce a margin of error of no more than about 3 percentage points.

\section{Margin of error (95\% confidence interval)}

\begin{tabular}{|c|c|c|c|c|c|c|c|c|c|c|}
\hline \multirow{2}{*}{$\begin{array}{l}\text { Survey } \\
\text { estimate }\end{array}$} & \multicolumn{10}{|c|}{ Sample size (n) } \\
\hline & 10 & 50 & 100 & 150 & 200 & 400 & 800 & 1000 & 2000 & 4000 \\
\hline $5 \%$ & $13.5 \%$ & $6.0 \%$ & $4.3 \%$ & $3.5 \%$ & $3.0 \%$ & $2.1 \%$ & $1.5 \%$ & $1.4 \%$ & $1.0 \%$ & $0.7 \%$ \\
\hline $10 \%$ & $18.6 \%$ & $8.3 \%$ & $5.9 \%$ & $4.8 \%$ & $4.2 \%$ & $2.9 \%$ & $2.1 \%$ & $1.9 \%$ & $1.3 \%$ & $0.9 \%$ \\
\hline $25 \%$ & $26.8 \%$ & $12.0 \%$ & $8.5 \%$ & $6.9 \%$ & $6.0 \%$ & $4.2 \%$ & $3.0 \%$ & $2.7 \%$ & $1.9 \%$ & $1.3 \%$ \\
\hline $50 \%$ & $31.0 \%$ & $13.9 \%$ & $9.8 \%$ & $8.0 \%$ & $6.9 \%$ & $4.9 \%$ & $3.5 \%$ & $3.1 \%$ & $2.2 \%$ & $1.5 \%$ \\
\hline $75 \%$ & $26.8 \%$ & $12.0 \%$ & $8.5 \%$ & $6.9 \%$ & $6.0 \%$ & $4.2 \%$ & $3.0 \%$ & $2.7 \%$ & $1.9 \%$ & $1.3 \%$ \\
\hline $90 \%$ & $18.6 \%$ & $8.3 \%$ & $5.9 \%$ & $4.8 \%$ & $4.2 \%$ & $2.9 \%$ & $2.1 \%$ & $1.9 \%$ & $1.3 \%$ & $0.9 \%$ \\
\hline $95 \%$ & $13.5 \%$ & $6.0 \%$ & $4.3 \%$ & $3.5 \%$ & $3.0 \%$ & $2.1 \%$ & $1.5 \%$ & $1.4 \%$ & $1.0 \%$ & $0.7 \%$ \\
\hline
\end{tabular}

(The values in the table are the margin of error - at $95 \%$ confidence level - for a given survey estimate and sample size) 


\section{Appendix 3}

\section{List of occupations}

D4. As far as your current occupation is concerned, would you say you are self-employed, an employee, a manual worker or would you say that you are without a professional activity? Does it mean that you are a(n)...

\section{- Self-employed}

i.e. : - farmer, forester, fisherman

- owner of a shop, craftsman

- professional (lawyer, medical practitioner, accountant, architect,...)... 13

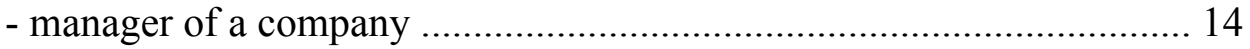

- other

- Employee

i.e. : - professional (employed doctor, lawyer, accountant, architect) ............ 21

- general management, director or top management.............................. 22

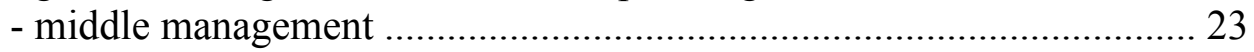

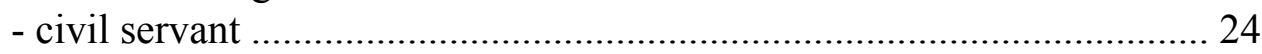

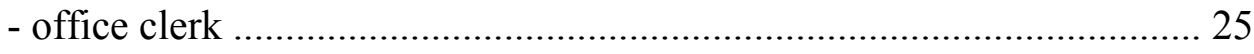

- other employee (salesman, nurse, etc...) .............................................. 26

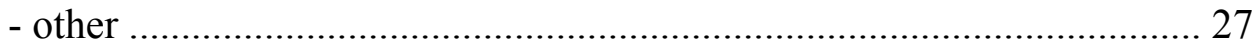

- Manual worker

i.e. : - supervisor / foreman (team manager, etc...) .31

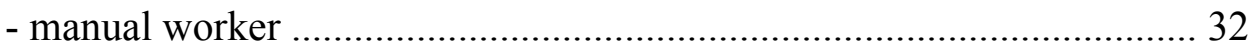

- unskilled manual worker ................................................................ 33

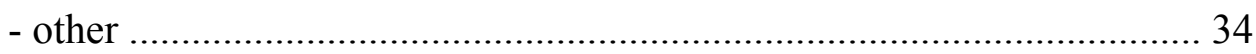

- Without a professional activity

i.e. : - looking after the home

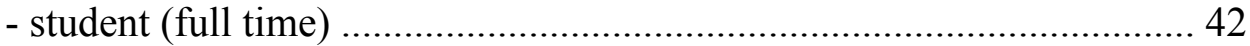

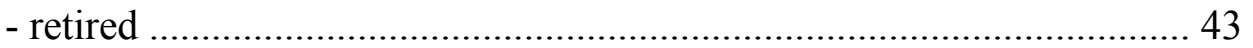

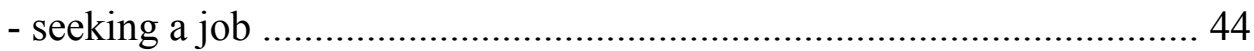

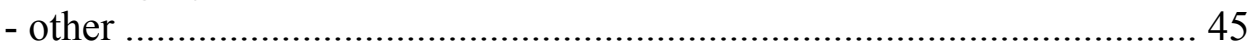

- [Refusal]

Source: Eurobarometer, 2009: p.86 
